\title{
Intermittent catheterisation for long-term bladder management (Review)
}

\author{
Prieto J, Murphy CL, Moore KN, Fader M
}

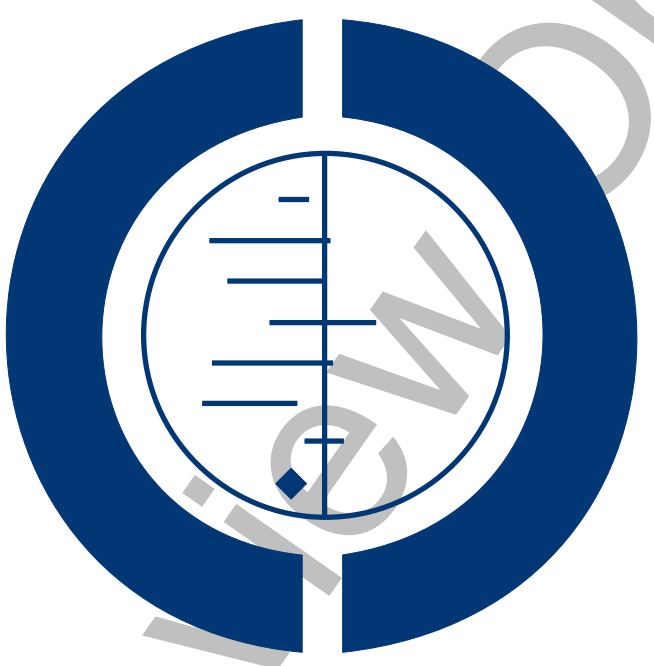

\section{THE COCHRANE COLLABORATION ${ }^{\circledR}$}

This is a reprint of a Cochrane review, prepared and maintained by The Cochrane Collaboration and published in The Cochrane Library 2014, Issue 9

http://www.thecochranelibrary.com

\section{WILEY}

Intermittent catheterisation for long-term bladder management (Review)

Copyright @ 2014 The Cochrane Collaboration. Published by John Wiley \& Sons, Ltd. 
TABLE OF CONTENTS

HEADER . . . . . . . . . . . . . . . . . . . . . . . . . . . . . . . . . . . . . . . . . . . . . . . . . . . . .

ABSTRACT . . . . . . . . . . . . . . . . . . . . . . . . . . . . . . . . . . . . . . . . . . . . . . . . . .

PLAIN LANGUAGE SUMMARY . . . . . . . . . . . . . . . . . . . . . . . . . . . . . . . . . . . . . . . . . . . .

BACKGROUND . . . . . . . . . . . . . . . . . . . . . . . . . . . . . . . . . . . . 3

OBJECTIVES . . . . . . . . . . . . . . . . . . . . . . . . . . . . . . . . . . . . . . . . . . .

METHODS . . . . . . . . . . . . . . . . . . . . . . . . . . . . . . . . . . . . . . . . . . . .

RESUlTS . . . . . . . . . . . . . . . . . . . . . . . . . . . . . . . . . . . . . . . . . 5

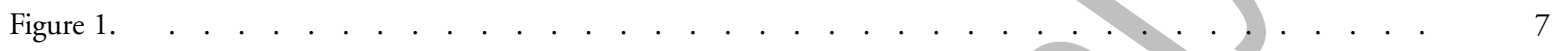

Figure 2.

Figure 3. . . . . . . . . . . . . . . . . . . . . . . . . . . . . . . . . . . . . . 11

DISCUSSION . . . . . . . . . . . . . . . . . . . . . . . . . . . . . . . . . . . . . . . . . . . . .

AUTHORS' CONCLUSIONS . . . . . . . . . . . . . . . . . . . . . . . . . . . . . . . . . . . . . . . . 18

ACKNOWLEDGEMENTS . . . . . . . . . . . . . . . . . . . . . . . . . . . . . . . . . . . 19

REFERENCES . . . . . . . . . . . . . . . . . . . . . . . . . . . . . . . . . . . . . . . . . . . . . 19

CHARACTERISTICS OF STUDIES . . . . . . . . . . . . . . . . . . . . . . . . . . . . . . . . . . . . . . . .

DATA AND ANALYSES . . . . . . . . . . . . . . . . . . . . . . . . . . . . . . . . . . . . . . . . . . . . . . . . . . .

Analysis 1.1. Comparison 1 Aseptic technique versus clean/other aseptic technique, Outcome 1 Number with asymptomatic bacteriuria. . . . . . . . . . . . . . . . . . . . . . . . . . . . . . . . . . . . .

Analysis 1.2. Comparison 1 Aseptic technique versus clean/other aseptic technique, Outcome 2 Number with symptomatic UTI.

Analysis 1.3. Comparison 1 Aseptic technique versus clean/other aseptic technique, Outcome 3 Weeks to onset of symptomatic UTI. . . . . . . . . . . . . . . . . . . . . . . . . . . . . . . . .

Analysis 2.1. Comparison 2 Single-ise (sterile) catheter versus multiple-use (clean) catheter, Outcome 1 Number with asymptomatic bacteriuria.

Analysis 2.2. Comparison 2 Single-ise (sterile) catheter versus multiple-use (clean) catheter, Outcome 2 Number with symptomatic UTI.

Analysis 2.3. Comparison 2 Single-ise (sterile) catheter versus multiple-use (clean) catheter, Outcome 3 Weeks to onset of symptomatic UTI.

Analysis 2.4. Comparison 2 Single-ise (sterile) catheter versus multiple-use (clean) catheter, Outcome 4 Number with microscopic haematuria.

Analysis 2.5. Comparison 2 Single-ise (sterile) catheter versus multiple-use (clean) catheter, Outcome 5 Number with urethral trauma/bleeding/macroscopic haematuria. . . . . . . . . . . . . . . . . . . . . .

Analysis 2.6. Comparison 2 Single-ise (sterile) catheter versus multiple-use (clean) catheter, Outcome 6 Number reporting overall satisfaction.

Analysis 2.7. Comparison 2 Single-ise (sterile) catheter versus multiple-use (clean) catheter, Outcome 7 Mean satisfaction.

Analysis 2.8. Comparison 2 Single-ise (sterile) catheter versus multiple-use (clean) catheter, Outcome 8 Number reporting ease of handling.

Analysis 2.9. Comparison 2 Single-ise (sterile) catheter versus multiple-use (clean) catheter, Outcome 9 Mean ease of handling.

Analysis 2.10. Comparison 2 Single-ise (sterile) catheter versus multiple-use (clean) catheter, Outcome 10 Number reporting ease of insertion.

Analysis 2.11. Comparison 2 Single-ise (sterile) catheter versus multiple-use (clean) catheter, Outcome 11 Mean ease of insertion.

Analysis 2.12. Comparison 2 Single-ise (sterile) catheter versus multiple-use (clean) catheter, Outcome 12 Number reporting comfort.

Analysis 2.13. Comparison 2 Single-ise (sterile) catheter versus multiple-use (clean) catheter, Outcome 13 Number reporting convenience of product.

Analysis 2.14. Comparison 2 Single-ise (sterile) catheter versus multiple-use (clean) catheter, Outcome 14 Mean convenience of product.

Analysis 3.1. Comparison 3 Hydrophilic-coated or other pre-lubricated catheter versus other catheter (pre-lubricated, coated or uncoated), Outcome 1 Number with asymptomatic bacteriuria. 
Analysis 3.2. Comparison 3 Hydrophilic-coated or other pre-lubricated catheter versus other catheter (pre-lubricated, coated or uncoated), Outcome 2 Number with symptomatic UTI.

Analysis 3.3. Comparison 3 Hydrophilic-coated or other pre-lubricated catheter versus other catheter (pre-lubricated, coated or uncoated), Outcome 3 Number of UTIs per month of use. . . . . . . . . . . . . . . . . . .

Analysis 3.4. Comparison 3 Hydrophilic-coated or other pre-lubricated catheter versus other catheter (pre-lubricated, coated or uncoated), Outcome 4 Number with urethral trauma/bleeding/macroscopic haematuria.

Analysis 3.5. Comparison 3 Hydrophilic-coated or other pre-lubricated catheter versus other catheter (pre-lubricated, coated or uncoated), Outcome 5 Number with microscopic haematuria.

Analysis 3.6. Comparison 3 Hydrophilic-coated or other pre-lubricated catheter versus other catheter (pre-lubricated, coated or uncoated), Outcome 6 Mean microscopic haematuria.

Analysis 3.7. Comparison 3 Hydrophilic-coated or other pre-lubricated catheter versus other catheter (pre-lubricated, coated or uncoated), Outcome 7 Number with stricture formation.

Analysis 3.8. Comparison 3 Hydrophilic-coated or other pre-lubricated catheter versus other catheter (pre-lubricated, coated or uncoated), Outcome 8 Number reporting overall satisfaction.

Analysis 3.9. Comparison 3 Hydrophilic-coated or other pre-lubricated catheter versus other catheter (pre-lubricated, coated or uncoated), Outcome 9 Mean Overall satisfaction.

Analysis 3.10. Comparison 3 Hydrophilic-coated or other pre-lubricated catheter versus other catheter (pre-lubricated, coated or uncoated), Outcome 10 Number reporting preference.

Analysis 3.11. Comparison 3 Hydrophilic-coated or other pre-lubricated catheter versus other catheter (pre-lubricated, coated or uncoated), Outcome 11 Number reporting convenience of product.

Analysis 3.12. Comparison 3 Hydrophilic-coated or other pre-lubricated catheter versus other catheter (pre-lubricated, coated or uncoated), Outcome 12 Mean convenience of product.

Analysis 3.13. Comparison 3 Hydrophilic-coated or other pre-lubricated catheter versus other catheter (pre-lubricated, coated or uncoated), Outcome 13 Number reporting ease of handling.

Analysis 3.14. Comparison 3 Hydrophilic-coated or other pre-lubricated catheter versus other catheter (pre-lubricated, coated or uncoated), Outcome 14 Mean ease of handling.

Analysis 3.15. Comparison 3 Hydrophilic-coated or other pre-lubricated catheter versus other catheter (pre-lubricated, coated or uncoated), Outcome 15 Number reporting ease of insertion.

Analysis 3.16. Comparison 3 Hydrophilic-coated or other pre-lubricated catheter versus other catheter (pre-lubricated, coated or uncoated), Outcome 16 Mean ease of insertion.

Analysis 3.17. Comparison 3 Hydrophilic-coated or other pre-lubricated catheter versus other catheter (pre-lubricated, coated or uncoated), Outcome 17 Number reporting comfort.

Analysis 3.18. Comparison 3 Hydrophilic-coated or other pre-lubricated catheter versus other catheter (pre-lubricated, coated or uncoated), Outcome 18 Mean ease of removal. . . . . . . . . . . . . . . . . . . . . . . . . . . .

Analysis 4.1. Comparison 4 Standard catheter versus shorter catheter length, Outcome 1 Number reporting ease of handling.

Analysis 4.2. Comparison 4 Standard catheter versus shorter catheter length, Outcome 2 Number reporting ease of insertion.

Analysis 4.3. Comparison 4 Standard catheter versus shorter catheter length, Outcome 3 Number reporting product discretion.

Analysis 4.4. Comparison 4 Standard catheter versus shorter catheter length, Outcome 4 Number reporting preference.

DECLARATIONS OF INTEREST . . . . . . . . . . . . . . . . . . . . . . . . . . . . . . . . . . . . . . . . . .

SOURCES OF SUPPORT . . . . . . . . . . . . . . . . . . . . . . . . . . . . . . . . . . . . . . . . . .

DIFFERENCES BETWEEN PROTOCOL AND REVIEW . . . . . . . . . . . . . . . . . . . . . . . . . . . . . . . . . . 


\title{
[Intervention Review] \\ Intermittent catheterisation for long-term bladder management
}

\author{
Jacqui Prieto $^{1}$, Catherine L Murphy ${ }^{1}$, Katherine N Moore ${ }^{2}$, Mandy Fader ${ }^{1}$ \\ ${ }^{1}$ Faculty of Health Sciences, University of Southampton, Southampton, UK. ${ }^{2}$ Faculty of Nursing, University of Alberta, Edmonton, \\ Canada \\ Contact address: Mandy Fader, Faculty of Health Sciences, University of Southampton, Room AA80, South Academic Block (Mail- \\ point11), Southampton General Hospital, Southampton, SO16 6YD, UK. m.fader@soton.ac.uk.
}

Editorial group: Cochrane Incontinence Group.

Publication status and date: New search for studies and content updated (no change to conclusions), published in Issue 9, 2014.

Review content assessed as up-to-date: 30 September 2013.

Citation: Prieto J, Murphy CL, Moore KN, Fader M. Intermittent catheterisation for long-term bladder management. Cochrane Database of Systematic Reviews 2014, Issue 9. Art. No.: CD006008. DOI: 10.1002/14651858.CD006008.pub3.

Copyright (C) 2014 The Cochrane Collaboration. Published by John Wiley \& Sons, Ltd.

\section{Background}

Intermittent catheterisation is a commonly recommended procedure for people with incomplete bladder emptying. There are now several designs of intermittent catheter (e.g. different lengths, 'ready to use' presentation) with different materials (e.g. PVC-free) and coatings (e.g. hydrophilic). The most frequent complication of intermittent catheterisation is urinary tract infection (UTI), but satisfaction, preference and ease of use are also important to users. It is unclear which catheter designs, techniques or strategies affect the incidence of UTI, which are preferable to users and which are most cost effective.

\section{Objectives}

To compare one type of catheter design versus another, one type of catheter material versus another, aseptic catheterisation technique versus clean technique, single-use (sterile) catheters versus multiple-use (clean) catheters, self-catheterisation versus catheterisation by others and any other strategies designed to reduce UTI and other complications or improve user-reported outcomes (user satisfaction, preference, ease of use) and cost effectiveness in adults and children using intermittent catheterisation for incomplete bladder emptying.

\section{Search methods}

We searched the Cochrane Incontinence Group Specialised Register, which contains trials identified from the Cochrane Central Register of Controlled Trials (CENTRAL), MEDLINE, MEDLINE in process, and handsearching of journals and conference proceedings (searched 30 September 2013), the reference lists of relevant articles and conference proceedings, and we attempted to contact other investigators for unpublished data or for clarification.

\section{Selection criteria}

Randomised controlled trials (RCTs) or randomised cross-over trials comparing at least two different catheter designs, catheterisation techniques or strategies.

\section{Data collection and analysis}

Two review authors assessed the methodological quality of trials and abstracted data. For dichotomous variables, risk ratios and $95 \%$ confidence intervals were derived for each outcome where possible. For continuous variables, mean differences and $95 \%$ confidence intervals were calculated for each outcome. Because of trial heterogeneity, it was not always possible to combine data to give an overall estimate of treatment effect.

Intermittent catheterisation for long-term bladder management (Review)

Copyright @ 2014 The Cochrane Collaboration. Published by John Wiley \& Sons, Ltd. 


\section{Main results}

Thirty-one trials met the inclusion criteria, including 13 RCTs and 18 cross-over trials. Most were small (less than 60 participants completed), although five trials had more than 100 participants. There was considerable variation in length of follow-up and definitions of UTI. Participant dropout was a problem for several trials, particularly where there was long-term follow-up to measure incidence of UTI. Fifteen trials were more than 10 years old and focused mainly on comparing different catheterisation techniques (e.g. single versus multiple-use) on clinical outcomes whereas, several more recent trials have focused on comparing different types of catheter designs or materials, especially coatings, and user preference. It was not possible to combine data from some trials owing to variations in the catheters tested and in particular the catheter coatings. Where there were data, confidence intervals around estimates were wide and hence clinically important differences in UTI and other outcomes could neither be identified nor reliably ruled out. No study assessed cost-effectiveness.

\section{Authors' conclusions}

Despite a total of 31 trials, there is still no convincing evidence that the incidence of UTI is affected by use of aseptic or clean technique, coated or uncoated catheters, single (sterile) or multiple-use (clean) catheters, self-catheterisation or catheterisation by others, or by any other strategy. Results from user-reported outcomes varied. The current research evidence is weak and design issues are significant. More well-designed trials are strongly recommended. Such trials should include analysis of cost-effectiveness because there are likely to be substantial differences associated with the use of different catheter designs, catheterisation techniques and strategies.

\section{PLAIN LANGUAGE SUMMARY}

\section{Intermittent catheterisation for long-term bladder management}

\section{Background}

Intermittent catheterisation is a common treatment used by people who have bladder emptying problems. A hollow tube (catheter) is passed through the channel to the bladder (urethra) or through a surgically made channel to the skin surface to regularly empty the bladder, usually several times every day. This treatment is used by people who have difficulty emptying their bladders themselves. However, this treatment often causes urine infections resulting in school or work absences or even hospitalisations.

\section{Review question}

There are different catheter designs and techniques which may affect urine infection. In this review we focused on urine infection in people who used different catheterisation techniques; different designs of catheter (coated [pre-lubricated] or uncoated [separate or no lubricant]); sterile (single-use) catheters or clean (multiple-use) catheters; self-catheterisation or catheterisation by others (such as parents or carers); and other strategies designed to reduce urine infection, including different ways of catheter cleaning for multipleuse. We also focused on user satisfaction, preference and ease of use.

\section{Study characteristics}

Studies on urine infection and intermittent catheterisation are difficult for researchers to undertake because participants need to take part for many months and tend to drop out. Many of the reviewed trials were too small and had problems with participants not wanting to continue in the trial. Definitions of urine infection also varied considerably. Thus well-designed and long-term trials are strongly recommended.

\section{Key results and quality of the evidence}

Thirty-one trials were included in the review. Currently, the evidence is weak and it is not possible to state that any catheter design, technique or strategy is better than another. Future research should consider cost as it is likely that there are big differences between different catheter designs and techniques. 


\section{B A C K G R O U N D}

Intermittent catheterisation (IC) is the act of passing a catheter into the bladder to drain urine via the urethra or other catheterisable channel such as a Mitrofanoff continent urinary diversion (surgically constructed passage connecting bladder with abdominal surface). The catheter is removed immediately after urine drainage is complete. It is widely advocated as an effective bladder management strategy for incomplete bladder emptying.

IC can be undertaken by people of all ages, including the very elderly and children as young as four years old with parental supervision. Carers can also be taught the procedure where this is acceptable both to the IC user and carer. Even some people with disabilities such as blindness, lack of perineal sensation, tremor, mental disability and paraplegia can learn how to master the technique (Cottenden 2013).

Individualised care plans should identify appropriate catheterisation frequency based on user goals, impact on quality of life, frequency-volume charts, functional bladder capacity and post voiding residual urine. The number of catheterisations per day varies; a general rule for adults is to catheterise frequently enough to avoid a bladder urine volume greater than $500 \mathrm{~mL}$ but clinical decisions are also provided by urodynamic findings, detrusor pressures on filling, presence of reflux and renal function.

Advantages of IC over indwelling catheterisation include:

- greater opportunity for self-care and independence;

- reduced risk of common indwelling catheter-associated complications, such as damage to the urethra or bladder neck, creation of false passages, persistent symptomatic urinary tract infection, stones in the bladder;

- reduced need for equipment and appliances e.g. drainage bag;

- greater freedom for expression of sexuality;

- potential for reduced urinary symptoms (frequency, urgency, incontinence) between catheterisations.

Reviewing the topic, Wyndaele 2002 provides a full discussion of the benefits as well as potential adverse effects of IC. Urinary tract infection (UTI) is the most frequent complication and catheterisation frequency and the avoidance of bladder over-filling are recognised as important prevention measures. It is recognised that prostatitis is a risk in men, but epididymitis and urethritis are relatively rare. Trauma from catheterisation, measured by haematuria, is reported but lasting effects appear limited. Estimates of the prevalence of urethral strictures and false passages increase with longer use of IC or with traumatic catheterisation. In a follow-up of children with spina bifida who had used IC with an uncoated PVC catheter and added lubricant for at least five years, the incidence of urethritis, false passage, or epididymitis was very low and adherence to the protocol was excellent (Campbell 2004). Wyndaele and colleagues concluded that the most important preventative measures were good education of all involved in IC, adherence to the catheterisation protocol, use of an appropriate catheter material and good catheterisation technique, although the level of evidence for these clinical opinions is weak.

Designs and characteristics of catheters used in IC vary considerably so evaluation and selection of products is complex. Plain uncoated catheters (typically clear plastic PVC) are packed singly in sterile packaging. As per industry standards, all disposable catheters are labelled for one time use but PVC catheters are frequently reused because of cost or concern about the environment. Most are used with separate lubricant, although this is a matter of personal choice, some IC users preferring not to use lubricant or just to use water. Cleansing of the catheter varies from being washed with soap and water, boiled, soaked in disinfectant, or microwaved. Cleaned catheters are air dried and then stored in a convenient container (often plastic containers or bags). Coated catheters are single-use only (they may not be cleaned and reused) and are designed to improve catheter lubrication and ease of insertion,which may (according to manufacturers) reduce trauma and UTI. The most common coating is hydrophilic, which is either pre-activated, or requires the addition of water at the time of use to form a lubricious layer. Some non-hydrophilic catheter designs are pre-lubricated (whereby the catheter is supplied pre-packed with a coating of water-soluble gel). There are also several prelubricated products with an integrated collection bag (all-in-one) which gives flexibility for the user and is efficient for hospital use. Finally, the design of catheters also varies, for example, length of catheter (standard versus more compact).

\section{Definition of terms}

1. Symptomatic UTI: a positive urine culture and the presence of symptoms, based on the UTI definition of the NIDRR 1992 (positive urine culture with pyuria and one or more systemic symptoms [fever, loin pain, dysuria, urgency, haematuria]). Some trials had varying definitions and we chose to accept symptomatic UTI as reported in the trials reviewed.

2. Asymptomatic bacteriuria: positive urine culture but absence of symptoms, again as reported in the trials.

3. Catheter design: different shapes, sizes, lengths and tips of catheter, different packaging

3a: Hydrophilic coated

i. Activated system, ready to use

ii. Activated closed system with integrated collection bag

iii. Not activated: sterile water provided in package for activation

iv. Not activated: water added by user

3b: Uncoated 
bag

i. Pre-lubricated closed system with integrated collection

ii. Pre-lubricated system with protective sleeve for no-touch insertion

iii. Non-lubricated: water-soluble gel added by user.

4. Catheter materials: the base material of the catheter (e.g. PVC, PVC-free, latex) and the presence or not of a bonded coating (e.g. hydrophilic).

5. Aseptic Technique (also referred to as 'sterile' technique in some older trials): sterile gloves, sterile single-use catheter, sterile cleansing solution, sterile drainage tray and an aseptic technique for the catheterisation procedure.

6. Clean technique: clean gloves (or no gloves in the case of a user self-catheterising), non-sterile cleansing solution and a clean receptacle in which to drain urine. It should be noted that an aseptic technique always includes a sterile (single-use) catheter whereas a clean technique may include a sterile catheter or a clean (multiple-use) catheter.

7. Sterile catheters: catheters removed from sterile packaging and used once only. Coated catheters have a hydrophilic or other lubricated coating intended to replace the need for separate lubricant. Coated catheters are not intended for re-use and are therefore defined as sterile.

8. Clean Catheters: Sterile catheters which are then re-used after cleaning, typically with soap and water and air dried. The material is uncoated. Lubricant may be applied before insertion.

\section{O B J E C T I VES}

To determine if certain designs of catheter, catheterisation technique, or other strategies (including re-use) are better than others in terms of UTI, complications, user satisfaction, preference, ease of use and/or cost-effectiveness for adults and/or children whose long-term (with no predicted endpoint) bladder management is by IC.

The following specific comparisons were addressed.

1. Aseptic technique versus clean/other aseptic technique

2. Single-use (sterile) catheter versus multiple-use (clean) catheter

3. Hydrophilic-coated or other pre-lubricated catheter versus other catheter (pre-lubricated, coated or uncoated)

4. One catheter length versus another catheter length

5. Any other techniques, strategies or designs that influence UTI, other complications or user-reported outcomes

\section{Criteria for considering studies for this review}

\section{Types of studies}

Randomised clinical trials, including cross-over trials, comparing catheterisation designs, techniques and other strategies for longterm bladder management by IC.

\section{Types of participants}

Adults or children requiring IC for long-term bladder management.

\section{Types of interventions}

Comparisons of intermittent catheter designs, catheterisation techniques and catheterisation strategies.

\section{Types of outcome measures}

1. Catheter-associated infection (definition of infection as used in trial reports)

- Symptomatic UTI (primary outcome variable)

- Asymptomatic bacteriuria

\section{Other complications/adverse effects}

- Urethral trauma/bleeding

- Creation of false passages

- Haematuria

- Stricture formation

\section{Participant-assessed outcomes}

- Comfort, including ease of insertion and removal

- Satisfaction

- Preferences

- Quality of life measures

\section{Economic outcomes}

- Catheter and equipment costs

- Frequency of catheterisation

- Resource implications (personnel and other costs to services)

- Formal economic analysis (cost-effectiveness, cost-utility)

- Days missed from employment/school

\section{METHODS}

Intermittent catheterisation for long-term bladder management (Review)

Copyright $\odot 2014$ The Cochrane Collaboration. Published by John Wiley \& Sons, Ltd. 


\section{Other outcomes}

- Microbiological culture of catheter surfaces

- Additional outcomes judged to be important when performing the review

\section{Search methods for identification of studies}

We did not impose any language or other limits on the searches.

\section{Electronic searches}

The review strategy was that developed for the Cochrane Incontinence Review Group. Relevant trials were identified from the Cochrane Incontinence Group Specialised Register of controlled trials which is described, along with the search strategy, under the Incontinence Group's module in The Cochrane Library. The Register contains trials identified from the Cochrane Central Register of Controlled Trials (CENTRAL), MEDLINE, MEDLINE in process, and handsearching of journals and conference proceedings. The Incontinence Group Specialised Register was searched using the Group's own keyword system. Search terms were:

topic.urine.incon*

AND

( $\left\{\right.$ design.cct $\left.{ }^{*}\right\}$ OR $\left\{\right.$ design.rct $\left.\left.{ }^{*}\right\}\right)$

AND

intvent.mech.cath*

(All searches were of the keyword field of Reference Manager

2012).

The date of the most recent search of the Register for this version of the review was 30 September 2013.

Extra specific searches were also performed by the review authors details of which are given in Appendix 1.

\section{Searching other resources}

We searched the reference lists of relevant articles and conference proceedings for other possible trials. We also contacted one investigator for clarification, which was provided (Cardenas 2011).

\section{Data collection and analysis}

\section{Trial selection}

To be comprehensive in the initial reviews, three review authors (JP, MF and KM) assessed each title and abstract of trials identified by the search strategy and a final list was agreed on. Full reports were obtained of all potentially relevant randomised controlled trials based on defined inclusion criteria.

The agreed list of eligible trials was then assessed independently by two of the review authors (JP and MF). Cochrane 'Risk of bias' forms were completed for all trials so that the quality of random allocation, concealment, description of dropouts and withdrawals, analysis by intention-to-treat, and blinding during intervention and at outcome assessment or any other potential biases were consistently addressed. Any disagreements between primary review authors (JP and MF) were also discussed with KM and CM and consensus reached.

\section{Methodological quality assessment}

The quality of eligible trials was assessed independently by two of the review authors (JP, MF) using the Cochrane 'Risk of bias' tool, which includes quality of random allocation and concealment, blinding during intervention and at outcome assessment, dropouts and withdrawals, and source of funding. When trial quality was assessed any disagreements between review authors were discussed and consensus reached. 'Risk of bias' forms were completed for all trials.

\section{Data abstraction}

Relevant data regarding inclusion criteria (trial design, participants, interventions and outcomes), quality criteria (randomisation, blinding and control) and results were extracted independently by two review authors using a data abstraction form developed specifically for this review. Excluded trials and reasons for exclusion have been detailed in the 'Characteristics of excluded studies table.

\section{RES U L T S}

\section{Description of studies}

\section{Results of the search}

In the original review (Moore 2007), we included 14 trials. For the current review an additional 33 were identified, of which 17 met the inclusion criteria. Two trials (Fader 2001; Pascoe 2001) excluded from the original review met the revised inclusion criteria. In all, 18 studies were excluded: one was a review, $17 \mathrm{did}$ not meet the review inclusion criteria. The final number was 31 trials addressing some aspect of sterile or clean intermittent catheterisation and using a measure of catheter-associated infection, other complication, or participant satisfaction.

Trial participants were mainly adults with spinal cord injuries, but also included other groups such as children with neurogenic bladders due to myelomeningocoele, men with prostatic obstruction and women with multiple sclerosis. Those trials that used infection as the primary outcome variable were generally of longer duration (three to 12 months) and those that focused on participant preference/ease of use were generally of shorter duration (eight weeks 
or less). There were variations in definitions of UTI. Attrition was a problem for several trials and most were underpowered. Fifteen trials were between 10 and 20 years old. The flow of literature through the assessment process is shown in the PRISMA diagram (Figure 1). 
Figure I. PRISMA study flow diagram

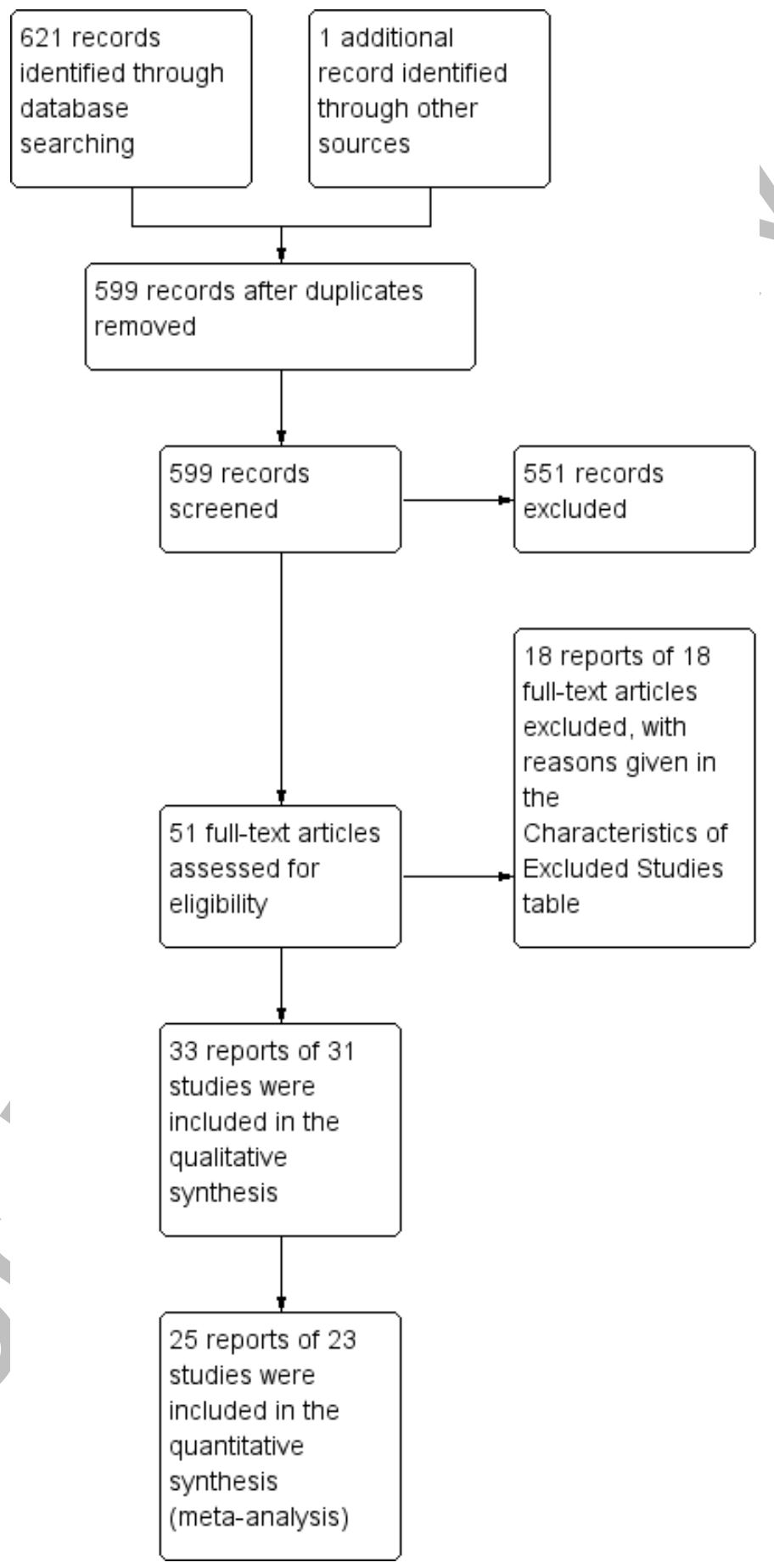




\section{Included Studies}

Thirty-one trials met the inclusion criteria (Biering-Sorensen 2007; Cardenas 2009; Cardenas 2011; Chartier-Kastler 2011; Chartier-Kastler 2013; Costa 2013; Day 2003; Denys 2012; De Ridder 2005; Domurath 2011; Duffy 1995; Fader 2001; Fera 2002; Giannantoni 2001; King 1992; Leek 2013; Leriche 2006; Mauroy 2001; Moore 1993; Moore 2006; Moore 2013; Pachler 1999; Pascoe 2001; Prieto-Fingerhut 1999; Quigley 1993; Sarica 2010; Schlager 2001; Sutherland 1996; Taweesangsuksalul 2005; Vapnek 2003; Witjes 2009).

Eight of the 31 trials did not provide data in a format that could be used in meta-analysis (Denys 2012; Fader 2001; Fera 2002; Giannantoni 2001; Mauroy 2001; Pascoe 2001, Sarica 2010; Taweesangsuksalul 2005).

\section{Design}

There were 13 parallel group randomised controlled trials ( Cardenas 2009; Cardenas 2011; Day 2003; De Ridder 2005; Duffy 1995; Fera 2002; King 1992; Moore 2006; Prieto-Fingerhut 1999; Quigley 1993; Sutherland 1996; Vapnek 2003; Witjes 2009).

The other 18 were cross-over randomised controlled trials:

- 15 with two arms (Biering-Sorensen 2007; Chartier-Kastler 2013; Chartier-Kastler 2011; Costa 2013; Denys 2012;

Domurath 2011; Giannantoni 2001; Leek 2013; Leriche 2006; Moore 1993; Moore 2013; Pachler 1999; Pascoe 2001; Schlager 2001; Taweesangsuksalul 2005);

- two with three arms (Mauroy 2001; Sarica 2010); and

- one with four arms (Fader 2001).

As the number of randomised trials was adequate for the review, it was not deemed necessary to include non-randomised trials. The inherent risk of bias in a non-randomised design makes the results difficult to apply to outcomes such as urinary tract infection. In particular, the studies reviewed had design limitations; non-randomisation would have compounded the limitations. However, further consideration could be given to the use of both non-randomised and qualitative studies to assess user opinion or cost-effectiveness.

\section{Sample sizes}

A total of 1737 participants were enrolled in the 31 trials with $1388(80 \%)$ of all participants completing data collection. However, in two studies involving a total of 224 participants, the completion rate was not stated and we have assumed that all participants completed.
In most trials the sample size was small. Only five of the 31 trials had a sample size of 100 or more (Cardenas 2011; Chartier-Kastler 2013; De Ridder 2005; Denys 2012; Witjes 2009).

Twelve trials included statistical power calculations (BieringSorensen 2007; Cardenas 2009; Cardenas 2011; Chartier-Kastler 2011; Chartier-Kastler 2013; De Ridder 2005; Domurath 2011; Fader 2001; Leek 2013; Moore 2006; Moore 2013; Witjes 2009) only one (Chartier-Kastler 2013) was able to achieve its predicted sample size.

At trial endpoint, sample sizes ranged from 10 (Schlager 2001; Taweesangsuksalul 2005) to 114 (Cardenas 2011) participants in total.

\section{Participants}

Trials included various types of patients using IC:

- spinal cord injury (Cardenas 2011; Day 2003; De Ridder

2005; Denys 2012; Domurath 2011; Giannantoni 2001; King

1992; Moore 2006; Prieto-Fingerhut 1999; Sarica 2010);

- patents with spinal cord injury who had experienced more than one UTI (Cardenas 2009);

- stroke (Quigley 1993);

- spinal cord lesion (Biering-Sorensen 2007; Chartier-Kastler 2011);

- prostatic obstruction from prostatic hyperplasia (Duffy 1995; Pachler 1999);

- children with spina bifida (Moore 1993; Moore 2013; Schlager 2001);

- spinal cord injury, Hinman syndrome, or spinal dysraphism (Sutherland 1996);

- neurogenic bladder disorders (Costa 2013;

Taweesangsuksalul 2005);

- vesico-sphincteric problem of neurological origin (Leriche 2006);

- a variety of diagnoses (Chartier-Kastler 2013; Fera 2002; Leek 2013; Mauroy 2001; Witjes 2009);

- no stated aetiology of the bladder dysfunction (Fader 2001; Pascoe 2001; Vapnek 2003).

Age and gender also varied:

- boys and girls with spina bifida (Moore 1993; Moore 2013; Schlager 2001);

- boys with neurogenic bladders (Sutherland 1996);

- adult men with prostatism (Duffy 1995; Pachler 1999);

- adult men with a vesico-sphincteric problem of neurological origin (Leriche 2006);

- adult men and women with spinal cord injury or lesion (Biering-Sorensen 2007; Cardenas 2009; Cardenas 2011; Chartier-Kastler 2011; Chartier-Kastler 2013; Day 2003; De 
Ridder 2005; Denys 2012Domurath 2011; King 1992; Moore 2006, Prieto-Fingerhut 1999; Sarica 2010);

- adult males and females with non-specified neurogenic bladder (Costa 2013; Leek 2013, Taweesangsuksalul 2005).

Twelve trials included only men as participants (Chartier-Kastler 2011; Day 2003; De Ridder 2005; Domurath 2011; Duffy 1995; King 1992; Leriche 2006; Fader 2001; Pachler 1999; Sarica 2010; Sutherland 1996; Vapnek 2003); and one included women only (Biering-Sorensen 2007). Age and gender were not stated in one (Quigley 1993), and gender was not stated in another (Pascoe 2001).

\section{Setting}

Settings ranged from:

- acute care within an intensive care unit (Day 2003);

- rehabilitation hospital (Biering-Sorensen 2007;

Giannantoni 2001; King 1992; Moore 2006; Prieto-Fingerhut 1999; Quigley 1993);

- spinal cord injury unit with follow-up in the community (Cardenas 2011);

- hospital outpatient clinic (Chartier-Kastler 2011; Fera 2002; Leek 2013; Leriche 2006; Martins 2009; Mauroy 2001; Sarica 2010);

- continuing or long-term care (Duffy 1995);

- paediatric clinic (Moore 2013);

- community (Cardenas 2009; De Ridder 2005; Fader 2001; Moore 1993; Pachler 1999; Pascoe 2001; Schlager 2001; Sutherland 1996; Vapnek 2003).

The setting was not described in six trials (Chartier-Kastler 2013; Costa 2013; Denys 2012; Domurath 2011; Taweesangsuksalul 2005; Witjes 2009).

\section{Types of interventions}

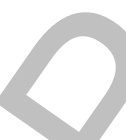

Interventions were separated into five main categories but in each of these there were variations in technique, catheter design and multiple-use versus single-use. In most cases there was no clear distinction made between self and caregiver/healthcare professional catheterisation. There were various comparisons made:

- aseptic versus clean or other aseptic technique (Day 2003, Duffy 1995; King 1992; Moore 2006; Prieto-Fingerhut 1999; Quigley 1993);

- single-use (sterile) catheters to multiple-use (clean) catheters (Duffy 1995; King 1992; Leek 2013; Moore 1993; Moore 2013; Pachler 1999; Prieto-Fingerhut 1999; Schlager 2001; Sutherland 1996; Vapnek 2003);

- hydrophilic-coated catheters or pre-lubricated catheters with standard (coated or uncoated) catheters (Cardenas 2009; Cardenas 2011; De Ridder 2005; Fader 2001; Leriche 2006; Mauroy 2001; Moore 2013; Pachler 1999; Pascoe 2001; Sarica 2010; Sutherland 1996; Vapnek 2003; Witjes 2009);
- uncoated catheter compared with a pre-lubricated catheter (Giannantoni 2001);

- one catheter length versus another length (Biering-Sorensen 2007; Chartier-Kastler 2011; Chartier-Kastler 2013; Costa 2013; Domurath 2011);

- one gel versus a standard gel (Fera 2002; Taweesangsuksalul 2005).

No trials were found comparing cleaning techniques or selfcatheterisation to catheterisation by others. The numbers add up to more than 31 since some trials fit into more than one category. Within these categories were various subcategories which are presented in detail in the Results section below.

\section{Duration of intervention}

In each arm of the cross-over trials participants were catheterised for either one catheterisation (Taweesangsuksalul 2005); one to two days (Biering-Sorensen 2007, Domurath 2011); one week (Fader 2001, Pascoe 2001); 12 to 14 days (Chartier-Kastler 2011); three to four weeks (Pachler 1999, Denys 2012); six to seven weeks (Sarica 2010, Giannantoni 2001); 12 weeks (Chartier-Kastler 2013), four months (Leek 2013, Schlager 2001); six months ( Moore 1993), 48 weeks (Moore 2013); or for the time required to use 10 catheters (Costa 2013), 20 catheters (Leriche 2006), or 27 catheters (Mauroy 2001).

In the 13 parallel group trials, the duration of intervention varied:

- 24 hours (Day 2003);

- four days (Quigley 1993);

- one month (King 1992; Witjes 2009);

- two months (Sutherland 1996);

- three months (Duffy 1995);

- four months (Fera 2002);

- up to six months (Cardenas 2011);

- up to 12 months (Cardenas 2009; De Ridder 2005; Moore 2006; Vapnek 2003);

- or was of unclear duration (Prieto-Fingerhut 1999).

\section{Outcome measures}

Twenty trials reported either symptomatic UTI or asymptomatic bacteriuria as the primary outcome measure (Cardenas 2009; Cardenas 2011; Day 2003; De Ridder 2005; Duffy 1995; Fera 2002; Giannantoni 2001; King 1992; Leek 2013; Mauroy 2001; Moore 1993; Moore 2006; Moore 2013; Pachler 1999; Prieto-Fingerhut 1999; Quigley 1993; Sarica 2010; Schlager 2001; Sutherland 1996; Vapnek 2003).

The definition of symptomatic UTI varied between trials from 'clinical infection with symptoms of UTI and for which treatment was prescribed' to $10 \times 5 \mathrm{CFU} / \mathrm{mL}$ (colony-forming units/millilitre) plus at least one of the following symptoms of fever, pyuria, haematuria, chills, increased spasms or autonomic dysreflexia. (See 
the Characteristics of included studies table for a complete description provided in each report).

Six trials reported on either microscopic or macroscopic haematuria (De Ridder 2005; Mauroy 2001; Moore 2013; Pachler 1999; Sutherland 1996; Vapnek 2003).

16 trials included user-reported outcomes (Biering-Sorensen 2007; Cardenas 2011; Chartier-Kastler 2011; Chartier-Kastler 2013; Costa 2013; Domurath 2011; Fader 2001; Giannantoni 2001; Leriche 2006; Mauroy 2001; Moore 2013; Pachler 1999; Pascoe 2001; Sarica 2010; Taweesangsuksalul 2005; Witjes 2009). Some trials reported overall satisfaction, others reported mean satisfaction. These results could not be combined as they provided dichotomous and continuous data. Moreover, the tools used to measure user-reported outcomes varied widely and only one trial used a validated tool (Chartier-Kastler 2011).

Although some of the trials included calculations of the costs of one catheter versus another, none of the trials undertook a formal evaluation of cost-effectiveness.

\section{Excluded trials}

Eighteen trials were excluded: one was a review, 17 did not meet the review inclusion criteria. (See the Characteristics of excluded studies table).

\section{On-going trials}

None known.

\section{Risk of bias in included studies}

Details of the quality of each trial are given in the 'Risk of bias' tables in Characteristics of included studies. The findings are summarised in Figure 2; Figure 3.

Figure 2. 'Risk of bias' graph: review authors' judgements about each risk of bias item presented as percentages across all included studies.

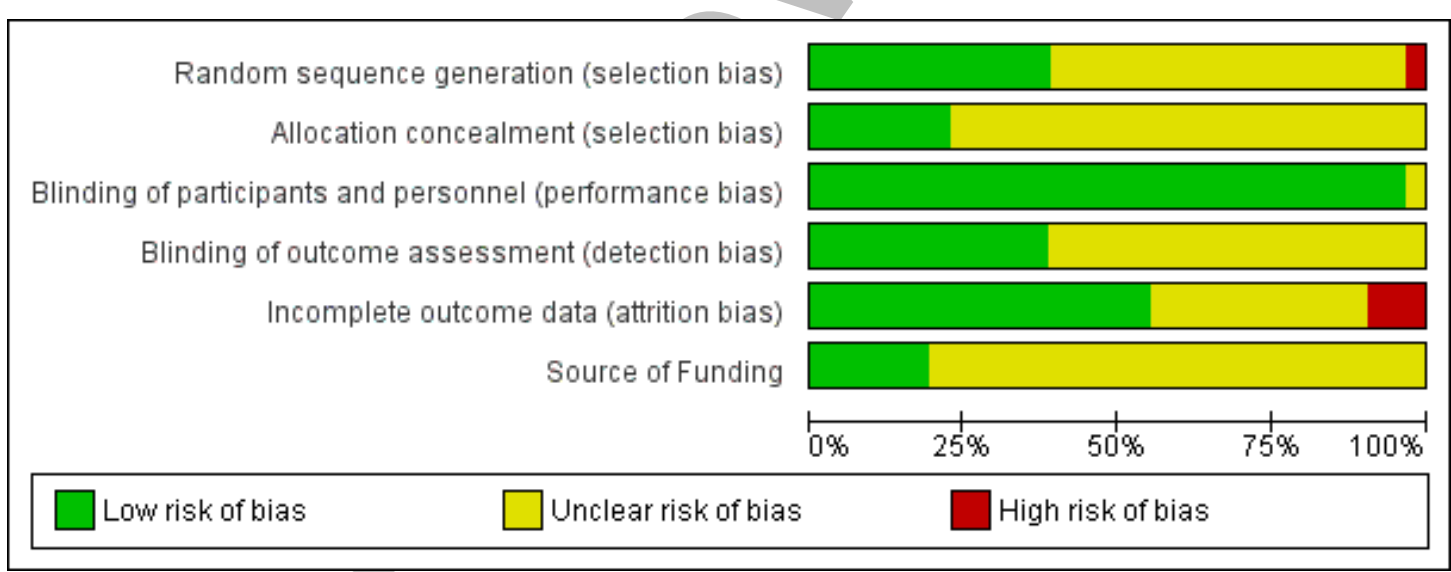


Figure 3. 'Risk of bias' summary: review authors' judgements about each risk of bias item for each included study.

\begin{tabular}{|c|c|c|c|c|c|c|}
\hline & 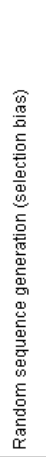 & 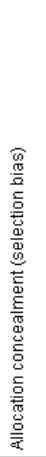 & 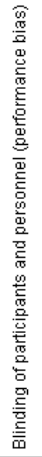 & 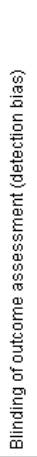 & 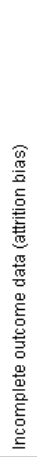 & 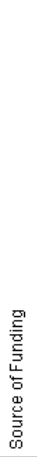 \\
\hline Biering-Sorensen 2007 & + & $?$ & + & 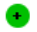 & + & $?$ \\
\hline Cardenas 2009 & $?$ & $?$ & 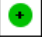 & $?$ & $\odot$ & $\odot$ \\
\hline Cardenas 2011 & $\odot$ & $\odot$ & $\odot$ & $?$ & $\odot$ & $?$ \\
\hline Chartier-Kastler 2011 & $\oplus$ & + & + & $?$ & $?$ & $?$ \\
\hline Chartier-Kastler 2013 & $\odot$ & $\odot$ & $\odot$ & $?$ & $?$ & $?$ \\
\hline Costa 2013 & $?$ & $?$ & $\odot$ & $?$ & $?$ & $?$ \\
\hline Day 2003 & $?$ & $?$ & + & $?$ & + & $?$ \\
\hline Denys 2012 & $?$ & $?$ & + & $?$ & + & $?$ \\
\hline De Ridder 2005 & $?$ & $?$ & $\odot$ & $\odot$ & $\Theta$ & $?$ \\
\hline Domurath 2011 & 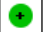 & $?$ & 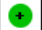 & $?$ & $?$ & $?$ \\
\hline Duffy 1995 & $?$ & $?$ & 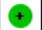 & $?$ & $?$ & $\odot$ \\
\hline Fader 2001 & + & $?$ & 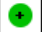 & $\odot$ & $?$ & $\odot$ \\
\hline Fera 2002 & ? & ? & + & + & + & ? \\
\hline Giannantoni 2001 & $?$ & $?$ & + & $?$ & + & $?$ \\
\hline King 1992 & $?$ & $?$ & + & $?$ & + & $\odot$ \\
\hline Leek 2013 & 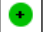 & + & $\odot$ & $\odot$ & $?$ & $?$ \\
\hline Leriche 2006 & $\odot$ & ? & + & $\odot$ & + & ? \\
\hline Mauroy 2001 & + & $?$ & + & $?$ & + & $?$ \\
\hline Moore 1993 & $?$ & $?$ & 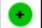 & $\odot$ & + & $?$ \\
\hline Moore 2006 & + & + & ? & $\odot$ & + & $\odot$ \\
\hline Moore 2013 & + & + & + & $\odot$ & $\Theta$ & $?$ \\
\hline Pachler 1999 & $?$ & $?$ & + & $?$ & $?$ & $?$ \\
\hline Pascoe 2001 & $?$ & $?$ & $\odot$ & $\odot$ & $?$ & $?$ \\
\hline Prieto-Fingerhut 1999 & $?$ & ? & + & $?$ & + & $?$ \\
\hline Quigley 1993 & $?$ & + & + & $?$ & + & $?$ \\
\hline Sarica 2010 & $\odot$ & $?$ & $\odot$ & $?$ & $?$ & $\odot$ \\
\hline Schlager 2001 & $?$ & $?$ & + & $?$ & + & ? \\
\hline Sutherland 1996 & $\theta$ & $?$ & + & $?$ & + & $?$ \\
\hline Taweesangsuksalul 2005 & $?$ & $?$ & + & $\odot$ & + & $?$ \\
\hline Vapnek 2003 & $?$ & $?$ & + & $?$ & $?$ & $?$ \\
\hline Witjes 2009 & $?$ & $?$ & + & $\odot$ & + & ? \\
\hline
\end{tabular}


As with the review in 2007, the trials as a whole were methodologically weak. They were generally underpowered with variations in outcomes, particularly with respect to the definition of UTI and outcomes addressing participant preference. In the previous review, some studies included bacteriuria in the absence of symptoms (asymptomatic bacteriuria) as an outcome. The updated search of trials reflected current practice in which asymptomatic bacteriuria is not considered clinically relevant as a marker for UTI and only one trial included this measure (Leek 2013). Follow-up ranged from 24 hours to 12 months; 15 of the 31 trials were more than 10 years old and were typically less rigorous in design and analysis. Attrition of participants was a particular problem (see below).

\section{Allocation}

The majority of the trial reports did not describe the method of allocation. In those that did, two (Moore 2006; Moore 2013) used opaque sealed envelopes opened by a third party who informed the research nurse of the assignment. De Ridder 2005 randomised participants in blocks of four and used opaque envelopes opened by the investigator but supplied from a central research office, and Quigley 1993 used 'blind selection of a marked piece of paper from a box'. Duffy 1995 did not describe method of randomisation but did indicate participants were stratified for research site or presence/absence of UTI. Eleven trials did not describe the method of randomisation, stating only that participants were 'randomised'.

\section{Blinding}

Mauroy 2001 masked all three test products. Other authors were unable to blind participants due to catheter packaging.

Data entry clerk and laboratory staff were blinded in six trials (Biering-Sorensen 2007; Leek 2013; Moore 2006; Moore 2013; Sarica 2010; Witjes 2009).

\section{Incomplete outcome data}

In three studies (Cardenas 2011; De Ridder 2005; Moore 2013), attrition bias was assessed to be high risk. In each study the rate of dropout was higher in the hydrophilic-coated arm compared to the uncoated arm.

In the De Ridder 2005 trial only 53\% of the participants in the standard (uncoated) catheter group and $41 \%$ of the participants in the treatment (hydrophilic-coated) catheter groups remained at the 12-month study endpoint. Similar challenges were met by Cardenas 2011 with $60 \%$ of participants remaining in the standard (uncoated) arm and $43 \%$ in the treatment (hydrophiliccoated) arm. Moore 2013 reported a completion rate of $75 \%$ in the standard (uncoated) arm and 62\% in the treatment (coated) arm. Reasons for dropouts in all three trials included loss to follow- up, preference for one study product, adverse events and withdrawing consent and improvement in voiding function as spinal cord injury healed. In the Cardenas 2011 and De Ridder 2005 trials, change in voiding status meant that some participants no longer required on-going IC.

\section{Other potential sources of bias}

\section{Intention-to-treat analysis}

Three authors described intention-to-treat analysis (ChartierKastler 2011; Moore 2006; Witjes 2009).

\section{Source of funding}

The source of funding was stated in 22 of the 31 studies, with 16 of those supported by industry (see 'Risk of bias' tables). In two of the 16 industry-supported studies it was stated that only products were supplied for testing, whereas in the other 14 studies the extent of funding was unclear.

\section{Effects of interventions}

\section{Comparison 0I: Aseptic technique versus clean/other aseptic technique.}

Six trials (Day 2003; Duffy 1995; King 1992; Moore 2006; PrietoFingerhut 1999; Quigley 1993) reported on types of catheterisation technique. Three trials (Day 2003; Prieto-Fingerhut 1999; Quigley 1993) compared an uncoated, pre-lubricated catheter with an integrated bag versus an uncoated, non-lubricated catheter to determine whether there was a difference in the incidence of UTI or asymptomatic bacteriuria. Whereas Day 2003 and Quigley 1993 used an aseptic technique in both arms, Prieto-Fingerhut used aseptic technique with the pre-lubricated catheter closed system and clean technique with the open system. Three trials (Duffy 1995; King 1992; Moore 2006) compared aseptic versus clean technique using uncoated, non-lubricated catheters.

\section{I.I Asymptomatic bacteruria}

Day 2003 and Moore 2006 both reported asymptomatic bacteriuria (Analysis 1.1). Day 2003 was a feasibility trial, which found that none of six participants in the closed system arm had asymptomatic bacteriuria compared to two out of five participants in the open system arm. For Moore 2006, the results were similar in the two groups (seven out of 16 for the aseptic arm versus nine out of 20 for the clean arm). The trials were too small to be reliable. 


\section{I.2 Symptomatic UTI}

Five out of the six trials reported symptomatic UTI (Duffy 1995; King 1992; Moore 2006; Prieto-Fingerhut 1999; Quigley 1993) (Analysis 1.2). All had wide confidence intervals and there was no apparent trend favouring either technique.

\section{I.3 Weeks to onset of UTI}

Three trials (Duffy 1995; King 1992; Moore 2006) measured mean time to onset of UTI. None showed statistically significant results favouring either technique (Analysis 1.3). Mean onset ranged from 4.3 weeks (aseptic group) and 4.6 weeks (clean group) (Moore 2006); 3.11 weeks (aseptic group) and 3.48 weeks (clean group (Duffy 1995); and 1.25 weeks (aseptic group) and 1.12 weeks (clean group) (King 1992).

\section{Comparison 02: Single-use (sterile) catheter versus multiple-use (clean) catheter}

Five parallel trials (Duffy 1995; King 1992; Prieto-Fingerhut 1999; Sutherland 1996; Vapnek 2003) and five two-arm crossover trials (Leek 2013; Moore 1993; Moore 2013; Pachler 1999; Schlager 2001) compared single-use (sterile) catheters with multiple-use (clean) catheters. Six used clean technique in both arms (Leek 2013; Moore 2013; Pachler 1999; Schlager 2001; Sutherland 1996; Vapnek 2003) and four trials used aseptic technique with the single-use catheter and clean technique with the multiple-use catheter (Duffy 1995; King 1992; Moore 1993; Prieto-Fingerhut 1999). Six compared one uncoated catheter used once with another uncoated catheter used multiple times (Duffy 1995; King 1992; Leek 2013; Moore 1993; Prieto-Fingerhut 1999; Schlager 2001). In these trials the uncoated, non-lubricated catheter used was the same in both arms, with the exception of Prieto-Fingerhut 1999 who compared an uncoated, prelubricated catheter with an integrated bag with an uncoated, nonlubricated catheter. Four compared a hydrophilic-coated (not activated) single-use catheter with an uncoated, non-lubricated (water added by user) multiple-use catheter (Moore 2013; Pachler 1999; Sutherland 1996; Vapnek 2003).

Trial time frames ranged from three weeks to 12 months. Cleaning methods varied as did the number of times the multiple-use catheter was re-used. Pachler 1999, King 1992 and Vapnek 2003 instructed participants to use the cleaned catheter for 24 hours; in the Duffy 1995 and Moore 2013 trials clean catheters were reused for one week; Sutherland 1996, Moore 1993, Schlager 2001 and Leek 2013 do not describe the number of re-uses of the noncoated catheter.

\section{I Number with asymptomatic bacteriuria}

Four cross-over trials reported on the prevalence of asymptomatic bacteriuria (Leek 2013; Moore 1993; Pachler 1999; Schlager
2001) (Analysis 2.1). None reported a significant difference between the two arms.

\subsection{Number with symptomatic UTI}

Eight studies reported on number of symptomatic UTI, four parallel trials (Duffy 1995; King 1992; Prieto-Fingerhut 1999; Sutherland 1996) and four cross-over studies (Leek 2013; Moore 2013; Pachler 1999; Schlager 2001) (Analysis 2.2). All lay across the no-difference line. We decided not to derive a summary estimate because of heterogeneity; however, there was no suggestion of a trend favouring either of the approaches.

\subsection{Weeks to onset of symptomatic UTI}

Two trials (Duffy 1995; King 1992) addressed weeks to onset of UTI and found no statistically significant differences (Analysis 2.3).

\subsection{Number with microscopic haematuria}

One RCT (Sutherland 1996) reported no significant difference in microscopic haematuria between arms (Analysis 2.4).

\subsection{Number with urethral trauma/bleeding/macroscopic bleeding}

One cross-over trial (Pachler 1999) reported on bleeding and no significant difference was found between arms (Analysis 2.5).

\subsection{Overall satisfaction}

The only trial reporting overall satisfaction as an outcome was Moore 2013, who found a slightly higher number (42/48) of participants reporting satisfaction with the multiple-use (uncoated) catheter compared to the single-use (hydrophilic-coated) catheter (35/48) (Analysis 2.6).

\subsection{Mean satisfaction}

Sutherland 1996 reported on mean satisfaction level with no statistical difference found (Analysis 2.7).

\subsection{Ease of handling}

The Pachler 1999 cross-over trial found no significant difference between arms. The Moore 2013 cross-over trial found in favour of the control arm (Analysis 2.8).

\subsection{Mean ease of handling}

Sutherland 1996 reported a mean ease of handling with no statistical difference found (Analysis 2.9). 


\subsection{Ease of insertion}

Pachler 1999 found no significant difference between the two arms for ease of insertion (Analysis 2.10).

\section{II Mean ease of insertion}

Sutherland 1996 found no significant difference in mean ease of insertion (Analysis 2.11).

\subsection{Number reporting comfort}

In the Moore 2013 trial there was no significant difference in reported comfort (Analysis 2.12).

\subsection{Convenience of product}

No significant difference in reported convenience of use was found by Moore 2013 (Analysis 2.13).

\subsection{Mean convenience of product}

Sutherland 1996 reported on mean convenience of product finding no significant difference between groups (Analysis 2.14).

\section{Comparison 03: Hydrophilic-coated or a pre- lubricated catheter versus other catheter (pre- lubricated, coated or uncoated)}

Fifteen trials compared a hydrophilic-coated catheter (activated or not activated) or a pre-lubricated catheter with one or more other catheters (pre-lubricated, coated or uncoated) (Cardenas 2009; Cardenas 2011; De Ridder 2005; Denys 2012, Fader 2001; Giannantoni 2001; Leriche 2006; Mauroy 2001; Moore 2013; Pachler 1999; Pascoe 2001; Sarica 2010; Sutherland 1996; Vapnek 2003; Witjes 2009). (See Characteristics of included studies table for full description of catheters used).

\section{I Asymptomatic bacteruria}

Only one trial reported asymptomatic bacteriuria (Pachler 1999). No significant difference was found between the arms (Analysis 3.1).

\subsection{Number with symptomatic UTI}

Six trials reported the number of symptomatic UTI (Cardenas 2009; De Ridder 2005; Moore 2013; Pachler 1999; Sutherland 1996; Vapnek 2003) (Analysis 3.2). The estimates from four of these trials (Cardenas 2011; Moore 2013; Pachler 1999; Sutherland 1996) had wide confidence intervals that straddled the no-difference line.

In one study (Vapnek 2003), the risk ratio was not estimable due to the way the data were reported.
In the largest trial (De Ridder 2005), the authors reported on the incidence of UTI of all enrolled participants $(\mathrm{N}=123)$, although the total number of UTIs was not reported. Only 57 participants (33/62 in the PVC arm; 25/61 in the hydrophilic arm) remained in the trial at the endpoint of 12 months and dropout was greater in the hydrophilic-coated catheter arm. There were fewer patients with one or more UTI in the hydrophilic-coated catheter group (i.e. results were better for the hydrophilic-coated catheters) and this was marginally statistically significant (39 out of 61 versus 51 out of 62 ; RR $0.78 ; 95 \%$ CI 0.62 to 0.97 ).

We chose not to derive a summary estimate because of the heterogeneity amongst the trials and the problem of attrition bias.

\subsection{Number of UTIs per month of use}

One trial Cardenas 2011 reported the number of UTIs per month of use, with the hydrophilic arm showing 41/207 and the uncoated $\operatorname{arm} 76 / 349$, which was not statistically significant (Analysis 3.3).

\subsection{Number with urethral trauma/bleeding/macroscopic} haematuria

Four trials reported on urethral trauma or visible bleeding. Cardenas 2011 noted a higher incidence in the hydrophilic cohort (14/105 versus 6/114) as did De Ridder 2005 (38/55 versus 32/ 59). One cross-over trial reported $0 / 29$ events in the hydrophilic arm and 5/29 in the standard arm (Leriche 2006). Pachler 1999 found no difference between groups. The combined data provided a confidence interval that straddled the no-difference line (Analysis $3.4)$.

\subsection{Number with microscopic haematuria}

Sutherland 1996 reported fewer cases of microscopic haematuria in the coated group (6/16 versus 11/14) (Analysis 3.5).

\subsection{Mean microscopic haematuria}

Moore 2013 reported on mean number of events of microscopic haematuria, finding no significant difference (Analysis 3.6).

\subsection{Number with stricture formation}

One event occurred in the coated group of the De Ridder trial (De Ridder 2005) (Analysis 3.7).

\subsection{Overall satisfaction}

Three trials addressed overall satisfaction with a hydrophilic product compared with another (De Ridder 2005; Moore 2013; Witjes 2009) (Analysis 3.8). One study (De Ridder 2005) reported higher satisfaction with the hydrophilic catheter; whereas another (Moore 2013) reported slightly higher satisfaction with the uncoated 
catheter. One study (Witjes 2009) compared two hydrophilic products, one PVC-based the other PVC-free and found that satisfaction was higher (statistically significant $\mathrm{P}=0.02$ ) with the PVC-based product.

\subsection{Mean overall satisfaction}

Cardenas 2011 and Sutherland 1996 reported statistically significant differences for users of the hydrophilic product over the uncoated catheter; Leriche 2006 also reported statistically significant differences in favour of hydrophilic catheter over uncoated, prelubricated catheter (Analysis 3.9). However, there was an imbalance in attrition in the Cardenas 2011 study, which meant that fewer patients have reported on preference in the hydrophilic arm. Those who did not remain in the study may have been less satisfied with the hydrophilic catheter than those who completed the study.

\subsection{Number reporting preference}

Three trials (De Ridder 2005; Leriche 2006; Pachler 1999) indicated that the hydrophilic product was preferred over the uncoated catheter. These differences were not statistically significant (Analysis 3.10).

\section{I I Number reporting convenience of product}

One cross-over trial (Moore 2013) found no significant difference between the two arms (Analysis 3.11).

\subsection{Mean convenience of product}

Sutherland 1996 reported on mean convenience of product, which did not vary significantly between products (Analysis 3.12).

\subsection{Number reporting ease of handling}

Thirty-one out of 32 participants in the Pachler 1999 two-arm cross-over trial reported handling the catheter to be either easy or tolerable in both arms (Analysis 3.13). In Moore 2013, ease of handling was acceptable in both groups with a trend favouring the uncoated catheter (29/49 hydrophilic group and 46/48 in the uncoated arm).

\subsection{Mean ease of handling}

Sutherland 1996 reported no significant difference in mean ease of handling (Analysis 3.14).

\subsection{Number reporting ease of insertion}

One RCT (Witjes 2009) and two cross-over trials (Leriche 2006; Pachler 1999) reported on ease of insertion. No significant difference was found (Analysis 3.15).

\subsection{Mean ease of insertion}

Cardenas 2011 and Sutherland 1996 reported on mean ease of insertion; no significant difference was found (Analysis 3.16).

\subsection{Mean ease of removal}

Cardenas 2011 found that mean ease of removal did not vary significantly between groups (Analysis 3.17).

\subsection{Number reporting comfort}

Moore 2013 found no significant difference in numbers reporting product comfort (Analysis 3.18).

\section{Studies without data added}

Six cross-over trials (Fader 2001, Mauroy 2001, Pascoe 2001, Sarica 2010, Denys 2012, Giannantoni 2001) compared one hydrophilic-coated catheter with one or more catheters (coated or uncoated), but did not provide data in a format that could be included in the data tables.

A key finding in Fader 2001, involving 61 participants, was that there were significant differences between four hydrophilic products (not activated, water added by user) with respect to user-reported severity of sticking and discomfort on withdrawal, userreported satisfaction and ease of use.

Mauroy 2001 reported on infection, haematuria, user-reported satisfaction and ease of use among 27 participants, but did not find any significant differences between the three hydrophilic (not activated, water added by user) products tested.

Pascoe 2001 randomised 27 participants to test two hydrophiliccoated catheters, one activated and one not activated (water added by user), and found no significant differences in performance, but users expressed a preference for the activated catheter.

Sarica 2010 compared the use of three catheters, one uncoated (not lubricated), one pre-lubricated with integrated bag and one hydrophilic-coated (water added by user), and reported an advantage in the pre-lubricated catheter for reduction in microscopic haematuria and improved comfort and handling. Only 10 of the 25 participants randomised completed the trial.

In Denys 2012, 97 participants completed a comparison of a new hydrophilic-coated catheter (not activated, sterile water supplied) versus a hydrophilic catheter (water added by user). Although a cross-over trial was undertaken, data on the control catheter were 
reported at baseline, but no further data on this group were reported.

Giannantoni 2001, a cross-over trial with 18 participants, compared a pre-lubricated catheter with protective sleeve versus an uncoated, non-lubricated catheter (water added by user). The outcomes were UTI, asymptomatic bacteriuria and participant preference; however as UTI and asymptomatic bacteriuria findings were reported per sample not per participant, it was not possible to include the data. The pre-lubricated catheter scored significantly better for comfort and ease of use.

\section{Comparison 4. One catheter length versus another catheter length}

Five two-arm cross-over trials compared a shorter catheter length with a standard catheter (Biering-Sorensen 2007; ChartierKastler 2011; Chartier-Kastler 2013; Costa 2013; Domurath 2011). Chartier-Kastler 2011 and Domurath 2011 compared hydrophilic-coated catheters (activated) in both arms. In BieringSorensen 2007 and Chartier-Kastler 2013 the shorter catheter was hydrophilic-coated (activated) and the standard catheters were various designs. Costa 2013 evaluated uncoated, pre-lubricated catheters (closed system with integrated collection bag) in both arms, the only difference being standard $(40 \mathrm{~cm})$ versus shorter $(30 \mathrm{~cm})$ length. All but one trial tested the catheters on male participants, Biering-Sorensen 2007 had female only participants. Participants in Biering-Sorensen 2007, Chartier-Kastler 2011; Chartier-Kastler 2013 and Domurath 2011 had either spinal cord injuries or lesions, and those in Costa 2013 were paraplegics requiring wheelchairs for mobility.

One study (Chartier-Kastler 2013) used a validated tool, the Intermittent Self-Catheterisation Questionnaire (ISC-Q) (Pinder 2012), reporting that more participants favoured the shorter catheter, however, only the difference in the total ISC-Q scores was reported, not each of the four domain scores (see Discussion section).

\section{I Number reporting ease of handling}

Chartier-Kastler 2011, Costa 2013 and Domurath 2011 reported on ease of handling (Analysis 4.1). Results were mixed, with Chartier-Kastler 2011 and Domurath 2011 reporting a preference for the shorter catheter, whereas participants in the Costa 2013 trial favoured the standard length catheter.

\subsection{Number reporting ease of insertion}

Both Chartier-Kastler 2011 and Domurath 2011 found more participants reported either positively or neutrally for ease of insertion for the shorter catheter compared to the standard catheter (28 out of 30 versus 22 out of 30 and 33 out of 36 versus 30 out of 36 respectively) and that a higher number of participants rated the shorter catheter as discrete or neutral compared to the standard catheter ( 34 out of 36 compared to 28 out of 36 and 28 out of 30 compared to 17 out of 30 respectively) (Analysis 4.2).

\subsection{Number reporting product discretion}

Chartier-Kastler 2011 and Domurath 2011 reported on product discretion reporting that significantly more participants found the shorter product more discrete (Analysis 4.3).

\subsection{Number reporting preference}

Domurath 2011, Costa 2013, Chartier-Kastler 2013 and BieringSorensen 2007 reported on user preference. Domurath 2011, Chartier-Kastler 2013 and Biering-Sorensen 2007 found in favour of the shorter catheter, but confidence intervals crossed the nodifference line. However, Costa 2013 found that very few participants preferred the shorter catheter (seven out of 81) (Analysis 4.4).

Comparison 5. Any other techniques, strategies or designs that influence UTI, other complications or satisfaction in adults and children using intermittent catheterisation for incomplete bladder emptying.

No randomised clinical trials that tested different cleaning methods and reported catheter-associated infection were found.

One RCT (Fera 2002) and one cross-over trial (Taweesangsuksalul 2005) were found which compared different gels used for lubricating catheters before insertion.

Fera 2002 compared gentamycin gel $(0.1 \%)$ versus lidocaine gel (2\%). There were 10 participants per arm and each used their allocated gel for four months. Urine analysis took place once every three weeks during the trial (a total of five samples for each participant). No significant difference was found in either the number of symptomatic UTIs or in occurrence of asymptomatic bacteriuria. Findings were potentially confounded due to four participants allocated to the lidocaine gel group receiving prophylactic antibiotics during the trial. Furthermore, two participants in the lidocaine group and one participant in the gentamycin group were treated for UTI during the trial and were taken out of the trial and returned following treatment.

Taweesangsuksalul 2005 compared participant satisfaction with Aloe vera gel versus an aqueous gel for lubricating the catheter before insertion. Ten participants used both lubricants and no significant difference was reported. It was not possible to include data as the satisfaction scale used was not reported.

\section{DISCUSSION}

\section{Summary of main results}


The purpose of the current review was to compare catheter designs, materials, technique and any other strategies to reduce UTI in long-term intermittent catheterisation (IC) users. A secondary aim was to compare user-reported outcomes (user satisfaction, preference, ease of use) associated with various catheter designs, techniques, and materials. Despite an additional 17 trials added to the database for a current total of 31 trials, there remains an absence of robust evidence to support one product or technique over another with respect to control of clinical symptoms, particularly symptomatic UTI. There is some statistical support for user preference of hydrophilic catheters but the confidence intervals are wide and there is a risk of bias due to higher dropout in the intervention arms. Thus the available data do not provide sufficient guidance to prescribing clinicians or users on which technique (aseptic/clean); catheter type (coated/uncoated); method (single/ multiple-use); person catheterising (self/other); or any other strategy is better than another. Clinicians will need to base their decisions on clinical judgement in conjunction with users. Differential costs of catheters/techniques may also inform decision-making.

\section{Updates since the last review}

The previous review (Moore 2007) found no convincing evidence that any specific technique, catheter design, method, person, or strategy was better than any other to minimise risk of UTI and other complications. The focus of that review was incidence of UTI related to IC. Our focus for the 2014 review expanded to include user-reported outcome data. This meant that two studies that had user preference as an outcome and that did not meet the inclusion criteria for the 2007 review were added to this review. Moreover, in the 2007 review, data reported in three cross-over trials were not included in the meta-analysis. In the current review we have been able to include data from cross-over trials, resulting in 12 additional trials (nine new and three from the previous review). However, data from the three cross-over trials with more than two arms has been discussed in the narrative, not added to the metaanalysis. Despite this number, there remains a lack of evidence that one catheter design or technique is superior to another in terms of control of symptomatic UTI.

\section{Overall completeness and applicability}

The number of potential permutations and combinations of techniques and catheters has led to problems with confounding, with several trials combining catheters and techniques such that it would not be possible to state the cause of any differences found. Large RCTs are needed to provide answers to each separate question (aseptic or clean technique; coated or uncoated catheter; single or multiple use, catheterisation by self or others). But because these trials are difficult to conduct and some combinations are much more commonly used than others, prioritisation is important. For example, aseptic versus clean technique question is of relatively low importance because in community settings (where most IC takes place) an aseptic technique is not practical. In hospital settings infection control policies indicate that an aseptic technique would be needed for safety.

A key clinical question remains the influence of catheters on UTI. The difficulty of establishing robust outcome measures of UTI remains problematic. Bacteriuria/positive culture is not clinically relevant unless accompanied by symptoms but the symptoms themselves may present in vague and imprecise ways, especially in adults with spinal cord injury where symptoms may be masked or unclear. However, despite these limitations symptomatic UTI remains the most clinically important primary outcome variable.

Men and women were not equally represented, limiting generalisability of results. Of the 29 trials that reported gender, there was a higher proportion of males $(60 \%)$ enrolling in the trial, the majority of whom had spinal cord injury. Thirteen trials enrolled only men, whereas one trial enrolled only women.

In community settings there are two important questions: single versus multiple-use; and coated versus uncoated catheter. In practice the most commonly used single-use catheter is a coated catheter which would need to be compared with a single-use uncoated catheter, to test if the coating is of importance. If coated catheters are not found to be superior then multiple-use uncoated catheters need to be compared with single-use uncoated catheters (to test if the sterility or single-use of the catheter is of importance). The latter question is of highest importance because it has the most substantial cost implications. Although coated catheters are more expensive than uncoated catheters, it is the single-use of the catheters (coated or uncoated) which makes this method of higher cost to individuals and health services.

There have been no RCTs comparing catheterisation by self compared with others. Moore (Moore 1993) presented descriptive data suggesting that there was no difference between the child selfcatheterising versus the parent. This question is of relatively low priority because catheterisation by others usually only takes place when the individual is not able to carry out the procedure themselves.

No RCTs comparing different methods of catheter cleaning were found when undertaking this review. We found a number of laboratory trials testing the sterility of catheters using different methods (cleaning with soap and water, chemical disinfection and microwave). Although most trials showed that pathogenic organisms were removed by cleaning, one trial testing the microwave method and one (incidentally) the soap and water method found residual pathogenic organisms. The clinical significance of these findings is unknown. The microwave method may be less practical than other methods due to the risk of catheter melting. No randomised controlled clinical trials of cleaning methods have been published and the comparative effectiveness of cleaning methods is therefore unknown. 


\section{Potential biases}

1. Attrition: In three of the five larger trials of long duration (Cardenas 2011; De Ridder 2005; Moore 2013) dropouts occurred early and were more frequent in the treatment arm, thus resulting in an imbalance and a potential bias in favour of the treatment catheter because there were fewer long-term data. In De

Ridder 2005, only 53\% of the standard (uncoated) catheter participants and $41 \%$ of the treatment (hydrophilic-coated) catheter participants remained at the 12-month study endpoint. Similar challenges were met by Cardenas 2011 with $60 \%$ of participants remaining in the standard (uncoated) arm and $43 \%$ in the treatment (hydrophilic-coated) arm. Moore 2013 also reported a completion rate of $75 \%$ in the standard (uncoated) arm and $62 \%$ in the treatment (coated) arm. Reasons for dropouts in all three trials included loss to follow-up, preference for one study product, adverse events and withdrawing consent and improvement in voiding function as spinal cord injury healed. In Cardenas 2011 and De Ridder 2005, change in voiding status meant that some participants no longer required on-going IC.

It should be noted that in all three trials, the uncoated group had a higher proportion of participant completions at the final analysis. Future trialists will require funds to support long-term and multicentre ventures that take into account the attrition challenges and the populations to be studied. Newly injured spinal cord individuals are attractive participants as their bladders are 'naive' to the long-term consequences of catheterisation. However, their bladder/voiding status can be unpredictable and may change to spontaneous voiding as healing occurs. Community dwelling users of ICs such as those with myelomeningocoele or multiple sclerosis are an alternative population as their conditions are relatively stable but their catheterisation habits are less easy to control and followup can be an issue.

2. Intention to treat (ITT): ITT analysis was declared by only two parallel arm trials (Moore 2006 and Witjes 2009).

3. Assessment of user-reported outcomes: 15 trials had userreported outcomes, 14 of which used questions that had not undergone standard psychometric testing and validation. ChartierKastler 2013 was the first trial to apply a newly developed and validated 24-item Intermittent Self-Catheterisation Questionnaire (ISC-Q), which evaluates aspects of quality of life specific to the needs of individuals performing ISC (Pinder 2012). The tool has four domains (ease of use, discreetness, convenience and psychological well-being) and a total score, although Chartier-Kastler 2013 only reported the total score.

In this review the most frequently reported outcome measures related to ease of use, with nine studies reporting ease of insertion and seven reporting ease of handling. Fewer studies reported outcomes relating to discreetness and convenience. Future studies would benefit from adopting a more consistent approach to the measurement of user-reported outcomes in assessing the benefit of one IC product over another.
4. There is a theoretical bias in cross-over trials where individuals will score the first product more favourably than the second. Chartier-Kastler 2013 was the only trial statistically addressing treatment sequence and reported no significant difference in scores.

\section{Reporting standards}

Reporting standards varied and not all trials followed the Consort guidelines, making it difficult to extract data. In those that followed good reporting standards, adverse events such as haematuria were clearly attributed to one of the trial arms.

\section{Agreement or disagreement with other reviews}

Two reviews have been published on the occurrence of UTI in IC users (Bermingham 2013; Li 2013). Bermingham et al created a Markov model to predict cost utility and QALY (quality-adjusted life year), using data from the randomised trials on IC. The authors conclude that multiple use is the most cost-effective type of IC. The authors also concluded, as we have, that there was limited evidence to support one catheter product over another with respect to symptomatic UTI. Of note is their conclusion that patients should be offered a choice between gel reservoir or hydrophilic catheters. Our review found no evidence to support this statement but we do agree with Bermingham et al that there is inadequate evidence to state that incidence of symptomatic UTI is affected by any one catheter design.

The second review (Li 2013) also sought to examine the benefit of one catheter design (hydrophilic versus non-hydrophilic) in the occurrence of UTI and haematuria. The authors concluded that both UTI and haematuria occurred less frequently with the use of hydrophilic-coated catheters. The authors' findings are not supported by our review. We suggest this may be related to the authors' errors of data extraction and interpretation including mistaking proportions for raw data in a forest plot, mixing laboratory trials (Stensballe 2005) with clinical trials, incorrect reporting of attrition leading to misleading conclusions, and finally, not reporting bleeding occurrences as well as microhaematuria which is worse in hydrophilic-coated arms where reported. Thus we disagree with the findings of the Li et al review that hydrophilic catheters reduce symptomatic urinary tract infections and reduce haematuria.

\section{A U THORS' CONCLUSIONS}

\section{Implications for practice}

There is still no convincing evidence that incidence of UTI is affected by use of aseptic or clean technique, coated or uncoated 
catheters, single (sterile) or multiple-use (clean) catheters or by any other strategy and user-reported outcomes varied. The question of whether healthcare providers should cover the cost of single-use products requires debate if no benefit over multiple-use products can be demonstrated. The variability in user-reported outcomes suggests patient choice could be important and there may be a benefit in combining single- and multiple-use for an individual.

\section{Implications for research}

There is lack of evidence demonstrating the effectiveness of any particular catheter design, technique or strategy. Variations in clinical practice and growth in the use of single-use catheters (particularly coated catheters) with associated increased costs mean that large well-designed parallel group RCTs are needed. RCTs are difficult in this area and prioritisation is necessary.

The most important pragmatic question (both for clinical and cost-effective reasons) is: Are multiple-use catheters equivalent to single-use catheters?

We recommend that the NIDRR 1992 definition of UTI is used as the primary outcome variable (positive urine culture with pyuria and one or more systemic symptoms (fever, loin pain, dysuria, urgency, haematuria). However, there is a need to validate these symptoms on IC users.

We recommend that a validated tool (e.g. Pinder 2012) is used to measure user acceptability.

Given the large differential costs for the methods, cost-effectiveness will need to be assessed rigorously.

To assist cost-effectiveness assessment, we recommend that userreported outcomes and health state utility are measured for different situations (e.g. home/out) as a secondary outcome variable. A validated outcome tool is required to allow comparisons across trials.

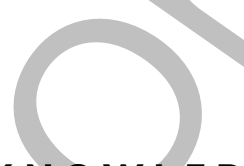

\section{ACKNOWLEDGEMENTS}

The authors thank Professor Kathryn Getliffe (retired) formerly at the University of Southampton and Ms. Jaycee Commance, MN, BSc, RN at the time a student at the University of Alberta for their work on the 2007 Review as well as the Cochrane Incontinence review group for thier invaluable assistance in completing the details of the review.

\section{REF ER E N C E S}

\section{References to studies included in this review}

Biering-Sorensen 2007 \{published data only\} Biering-Sorensen F, Hansen HV, Nielsen PN, Looms D. Residual urine after intermittent catheterization in females using two different catheters. Scandinavian Journal of Urology and Nephrology 2007;41:341-5.

Cardenas 2009 \{published data only\} Cardenas DD, Hoffman JM. Hydrophilic catheters versus noncoated catheters for reducing the Incidence of urinary tract infections: a randomized controlled trial. Archives of Physical Medicine and Rehabilitation 2009;90(10):1668-71.

Cardenas 2011 \{published data only\} Cardenas DD, Moore KN, Dannels-McClure A, Scelza WM, Graves DE, Brooks M, et al.Intermittent catheterization with a hydrophilic-coated catheter delays urinary tract infections in acute spinal injury: a prospective randomised, multicenter trial. Physical Medicine and Rehabilitation 2011;3:408-17.

Chartier-Kastler 2011 \{published data only\} Chartier-Kastler E, Lauge I, Ruffion A, Goossens D, Charvier K, Biering-Sorensen F. Safety of a new compact catheter for men with neurogenic bladder dysfunction: a randomised, crossover and open-labelled study. Spinal Cord 2011;49(7):844-50.
Chartier-Kastler 2013 \{published data only\} Chartier-Kastler E, Amarenco G, Lindbo L, Soljanik I, Andersen HL, Bagi P, et al.A prospective, randomized, crossover, multicenter study comparing quality of life using compact versus standard catheters for intermittent selfcatheterization. Journal of Urology 2013;190(3):942-7.

Costa 2013 \{published data only\}

Costa J, Menier M. Catheter length preference in wheelchair bound male patients who perform clean intermittent catheterisation (Abstract number 38). Neurourology and Urodynamics 2012;31(6):773-4.

* Costa J, Menier M, Doran T, Köhler T. Catheter length preference in wheelchair-using men who perform routine clean intermittent catheterization. Spinal Cord 2013;51 (10):772-5.

\section{Day 2003 \{published data only\}}

Day RA, Moore KN, Alberts MK. A pilot trial comparing two methods of intermittent catheterization: Limitations and challenges. Urologic Nursing 2003;23(2):143-7,158.

Denys 2012 \{published data only\}

Denys P, Previnaire J, Aegerter P, Seze M, Karsenty G, Amarenco G. Intermittent self-catheterisation habits and opinion on aseptic VaPro catheter in French neurogenic bladder population. Spinal Cord 2012;50:853-8.

De Ridder 2005 \{published and unpublished data\} De Ridder DJMK, Everaert K, Fernandez LG, Valero 
JVF, Duran AB, Abrisqueta MLJ, et al.Intermittent catheterisation with hydrophilic-coated catheters (Speedicath) reduces the risk of clinical urinary tract infection in spinal cord injured patients: a prospective randomzied parallel comparative trial. European Urology 2005;48(6):991-5.

\section{Domurath 2011 \{published data only\}}

Domurath B, Kutzenberger J, Kurze I, Knoth H. Clinical evaluation of a newly developed catheter(SpeediCath Compact Male) in men with spinal cord injury:residual urine and user evaluation. Spinal Cord 2011;49:817-21.

Duffy 1995 \{published data only\} Duffy LM, Cleary J, Ahern S, Kuskowski MA, West M, Wheeler L, et al.Clean intermittent catheterization: Safe, Cost-effective bladder management for male residents of VA nursing homes. Journal of the American Geriatrics Society 1995;43(8):865-70. [: 1058]

Fader 2001 \{published data only\} Fader M, Moore KN, Cottenden AM, Pettersson L, Brooks R, Malone-Lee J. Coated catheters for intermittent catheterization: smooth or sticky?. British Journal of Urology International 2001;88 (4):373-7.

Fera 2002 \{published data only\}

Fera P. Lubricated urethral catheters with lidocaine versus gentamycin for clean intermittent catheterization. Brazilian Journal of Urology 2002;28(1):50-6. [: 18009]

Giannantoni 2001 \{published data only\} Giannantoni A, Di Stasi SM, Scivoletto G, Virgili G, Dolci S, Porena M. Intermittent catheterization with a prelubricated catheter in spinal cord injured patients: a prospective randomized crossover trial. Journal of Urology 2001;166(1):130-3. [: 15635]

King 1992 \{published data only\} King RB, Carlson CE, Mervine J, Wu Y, Yarkony GM. Clean and sterile intermittent catheterization methods in hospitalized patients with spinal cord injury. Archives of Physical Medicine \& Rehabilitation 1992;73(9):798-802. [: 1360]

Leek 2013 \{published data only\}

Leek H, Stephenson Z, Reus A, Karantanis E, Moore KH. Clean intermittent self-catheterisation: A randomised controlled crossover trial of single-use versus multiple re-use of non-coated catheters; is cystitis rate altered? (Abstract number 170). Neurourology and Urodynamics 2012;32(6): $759-60$.

Leriche 2006 \{published data only\}

Leriche A, Charvier K, Bonniaud B, Peyrat L, N'Guyen P, Soler J, et al.An acceptability study: Speedicath set vs Actreen set in patients practicing self-catheterisation. Progres en Urologie 2006;16:347-51.

Mauroy 2001 \{published data only\} Mauroy B, Soret J, Bonnal J, Fantoni J. Comparison between three intermittent catheters: a prospective study in a group of 27 patients. Annals of Urology 2001;35:223-8.
Moore 1993 \{published data only\}

Moore KN, Kelm M, Sinclair O, Cadrain G. Bacteriuria in intermittent catheterization users: the effect of sterile versus clean reused catheters. Rehabilitation Nursing 1993;18(5): 306-9. [: 1208]

Moore 2006 \{published data only\} Moore KN, Burt J, Voaklander D. Intermittent catheterization in the rehabilitation setting: a comparison of clean and sterile technique. Clinical Rehabilitation 2006; 20(6):461-8.

\section{Moore 2013 \{published data only\}}

Moore KN, Kiddoo D, Sawatzky B, Afshar K, Dharamsi N, Bascu C, et al.Randomised crossover trial of hydrophilic single use versus PVC multiuse catheters for $\mathrm{CIC}$ in children with neural tube defects (spina bifida) (Abstract number 171). Neurourology and Urodynamics 2013;32(6):760-1.

\section{Pachler 1999 \{published data only\}}

* Pachler J, Frimodt-Moller C. A comparison of prelubricated hydrophilic and non-hydrophilic polyvinyl chloride catheters for urethral catheterization. BJU International 1999;83(7):767-9.

Pachler J, Frimodt-Moller C. Pre-lubricated hydrophilic pvc urethral catheters compared to non-hydrophilic pvc catheters. Proceedings of the International Continence Society (ICS), 28th Annual Meeting; 1998 Sept 14-17; Jerusalem, Israel 1998:325. [: 5702]

\section{Pascoe 2001 \{published data only\}}

Pascoe G, Clovis S. Evaluation of two coated catheters in intermittent self-catheterisation. British Journal of Nursing 2001;10(5):325-9.

Prieto-Fingerhut 1999 \{published data only\} Prieto-Fingerhut T, Banovac K, Lynne CM. A trial comparing sterile and nonsterile urethral catheterization in patients with spinal cord injury. Rehabilitation Nursing 1997;22(6):299-302. [: 5491]

\section{Quigley 1993 \{published data only\}}

Quigley PA, Riggin OZ. A comparison of open and closed catheterization techniques in rehabilitation patients. Rehabilitation Nursing 1993;18:26-9,33. [: 2345]

\section{Sarica 2010 \{published data only\}}

Sarica S, Akkoc Y, Karapolat H, Aktug H. Comparison of the use of conventional, hydrophilic and gel-lubricated catheters with regard to urethral micro trauma, urinary system infection, and patient satisfaction in patients with spinal cord injury: a randomized controlled study. European Journal of Physical and Rehabilitation Medicine 2010;46: 473-80.

\section{Schlager 2001 \{published data only\}} Schlager TA, Clark M, Anderson S. Effect of a single-use sterile catheter for each void on the frequency of bacteriuria in children with neurogenic bladder on intermittent catheterization for bladder emptying. Pediatrics 2001;198 (4):e71. 
Sutherland 1996 \{published data only\}

Sutherland RS, Kogan BA, Baskin LS, Mevorach RA. Clean intermittent catheterization in boys using the LoFric catheter. Journal of Urology 1996;156(6):2041-3. [: 4867]

Taweesangsuksalul 2005 \{published data only\} Taweesangsuksakul R, Tamnanthong N, Hanpanich K, Chobchuen R, Kirdpon W. Effect of aloe vera for lubrication on urethral catheterisation. Journal of Thail Rehabilitation Medicine 2005;15(2):113-8.

Vapnek 2003 \{published data only\}

Vapnek JM, Maynard FM, Kim J. A prospective randomized trial of the LoFric hydrophilic coated catheter versus conventional plastic catheter for clean intermittent catheterization. Journal of Urology 2003;169(3):994-8. [: 15588]

Witjes 2009 \{published data only\}

Witjes JA, Del Popolo G, Marberger M, Jonsson O, Kapsand HP, Chapple CR. A multicenter, double-blind, randomized, parallel group study comparing polyvinyl chloride and polyvinyl chloride-free catheter materials. Journal of Urology 2009;182(6):2794-8.

\section{References to studies excluded from this review}

Bagi 2011 \{published data only\}

Bagi P, Hannibalsen J, Permild R, Stilling S, Looms D. Safety of a new compact male intermittent catheter: randomized, cross-over, single-blind study in healthy male volunteers. Urology International 2011;86(2):179-84.

Bennett 1997 \{published data only\}

Bennett C, Young M, Razi S, Adkins R, Diaz F, McCrary A. The effect of urethral introducer tip catheters on the incidence of urinarytract infection outcomes in spinal cord injured patients. Journal of Urology 1997;158(2):519-21.

Charbonneau 1993 \{published data only\}

Charbonneau-Smith R. No-touch catheterization and infection rates in a select spinal cord injured population. Rehabilitation Nursing 1993;18:296-9,305,355-6. [: 2282]

Clarke 2005 \{published data only\}

Clarke SA, Samuel M, Boddy S. Are prophylactic antibiotics necessary with clean intermittent catheterization? A randomised controlled trial. Journal of Pediatric Surgery 2005;40(3):568-71

Diokno 1995 \{published data only\}

Diokno AC, Mitchell BA, Nash AJ, Kimbrough JA. Patient satisfaction and the LoFric catheter for clean intermittent catheterization. Journal of Urology 1995;153(2):349-51.

Edokpolo 2012 \{published data only\}

Edokpolo L, Stavris K, Foster H. Intermittent catheterization and recurrent urinary tract infection in spinal cord injury. Topics in Spinal Cord Rehabilitation 2012;18(2):187-92.

Feng 2009 \{published data only\}

Feng X, Ren Y, Wei D, Liu C. Clinical observation on moxibustion combined with intermittent urethral catheterization for treatment of neurogenic vesical dysfunction. Zhongguo Zhen Jiu 2009;28(2):21-9.
Grigoleit 2006 \{published data only\}

Grigoleit U, Pannek J, Stohrer M. Single-use intermittent catheterisation][German] [Der Intermittierende Einmalkatheterismus]. Urologe 2006;45(2):175-82.

Hosseini 2008 \{published data only\}

Hosseini J, Kaviani A, Golshan AR. Clean intermittent catheterization with triamcinolone ointment following internal urethrotomy. Urology Journal 2008;5(4):265-8.

Hudson 2005 \{published data only\}

Hudson E, Murahata RI. The 'no-touch' method of intermittent urinary catheter insertion: can it reduce the risk of bacteria entering the bladder?. Spina Cord 2005;43: 611-4.

Litherland 2007 \{published data only\} Litherland A, Schlotz H. Patient-perceived discomfort with two coated urinary catheters. British Journal of Nursing 2007;16(5):284-7.

Martins 2009 \{published data only\} Martins M, Santos V, Secoli S, Mata M, Nogueira D, de Souza D. A comparison between two catheters for clean intermittent catheterisation in continent children with a urostomy. Revista Da Escola de Enfermagem Da USP 2009; 43(4):865-71.

Nalinthip 1996 \{published data only\}

Nalinthip T. Urinary tract infection in self-catheterisation compared to nurse-catheterisation for bladder training in patients with spinal cord lesion (Abstract). Srinagarind Medical Journal 1996;11(4):345.

\section{Sallami 2011 \{published data only\}}

Sallami S, Mouine Y, Rhouma S, Cherif K, Dahmani A, Horchani A. Clean intermittent catheterization following urethral stricture surgery using a low friction catheter versus conventional plastic catheter: a prospective, randomized trial. UroToday International Journal 2011; Vol. 4, issue 2. [DOI: 10.3834/uij.1944-5784.2011.04.07]

Sherbondy 2002 \{published data only\}

Sherbondy AL, Cooper CS, Kalinowski SC, Boyt MA, Hawtrey CE. VAriability in catheter microwave sterilization techniques in a single clinic population. Journal of Urology 2002;168(2):562-4.

Sims 1993 \{published data only\} Sims L, Ballard N. A comparison of two methods of catheter cleansing and storage used with clean intermittent catheterization. Rehabilitation Nursing Research 1993;2: 87-92. [: 2279]

Stensballe 2005 \{published data only\} Stensballe J, Looms D, Nielsen PN, Tvede M. Hydrophiliccoated catheters for intermittent catheterisation reduce urethral micro trauma: a prospective, randomised, participant-blinded, crossover trial of three different types of catheters. European Urology 2005;48(6):978-83. [: 21523]

Terpenning 1989 \{published data only\}

Terpenning MS, Allada R, Kauffman CA. Intermittent catheterization in the elderly. Journal of the American Geriatrics Society 1989;37(5):411-6. 


\section{Additional references}

\section{Bermingham 2013}

Bermingham S, Hodgkinson S, Wright S, Hayter E, Spinks J, Pellowe C. Intermittent self catheterisation with hydrophilic, gel reservoir, and non-coated catheters: a systematic review and cost effectiveness analysis. BMJ 2013; Vol. 346, issue e8639:e1-e16. [DOI: 10.1136/bmj.e8639]

\section{Campbell 2004}

Campbell J, Moore KN, Voaklander D, Mix, L.

Complications associated with clean intermittent catheterization in children with spina bifida. Journal of Urology 2004;171(6 Pt 1):2420-2.

\section{Cottenden 2013}

Cottenden A, Bliss DZ, Buckley B, Fader M, Gartley C, Hayder D, et al.Management using continence products. In: Abrams P, Cardozo L, Khoury S, Wein A editor(s). Incontinence: 5th International Consultation on Incontinence. Recommendations of the International Scientific Committee: Evaluation and Treatment of Urinary Incontinence, Pelvic Organ Prolapse and Faecal Incontinence; 2012 Feb 23-25; Paris. 5th Edition. Belgium: International Consultation on Urological Diseases (ICUD), 2013:1651-786.

\section{Li 2013}

Li L, Ye W, Ruan H, Yang B, Zhang S, Li L. Impact of hydrophilic catheters on urinary tract infections in people with spinal cord injury: systematic review and meta-analysis of randomized controlled trials. Archives of Physical Medicine and Rehabilitation 2013;94(4):782-7.

\section{NIDRR 1992}

National Institute on Disability and Rehabilitation Research (NIDRR). The prevention and management of urinary tract infections among people with spinal cord injuries.

National Institute on Disability and Rehabilitation Research Consensus Statement. January 27-29, 1992. Journal of the American Paraplegia Society 1992;15(3):194-204.

\section{Pinder 2012}

Pinder B, Lloyd AJ, Elwick H, Denys P, Marley J, Bonniaud $\mathrm{V}$. Development and psychometric validation of the intermittent self-catheterization questionnaire. Clinical Therapeutics 2012;34(12):2302-13.

\section{Reference Manager 2012}

Reference Manager Professional Edition Version 12. New York: Thomson Reuters 2012.

Wyndaele 2002

Wyndaele JJ. Complications of intermittent catheterization: their prevention and treatment. Spinal Cord 2002;40(10): $536-41$.

\section{References to other published versions of this review}

Moore 2007

Moore KN, Fader M, Getliffe K. Long-term bladder management by intermittent catheterisation in adults and children. Cochrane Database of Systematic Reviews 2007, Issue 4. [DOI: 10.1002/14651858.CD006008.pub2]

* Indicates the major publication for the study 


\section{CHARACTERISTICS OF STUDIES}

\section{Characteristics of included studies [ordered by study ID]}

\section{Biering-Sorensen 2007}

Methods

DESIGN: Randomised controlled cross-over trial

BLINDING PROCEDURES: Single blind (to investigator)

SAMPLE CALCULATION: Yes

DURATION: 2 days

WITHDRAWALS/DROPOUTS: Not stated

ITT: Not applicable

GEOGRAPHICAL LOCATION: Denmark

SETTING: Outpatient clinic

\begin{tabular}{|c|c|c|}
\hline Participants & \multicolumn{2}{|c|}{$\begin{array}{l}\text { N }=24 \\
\text { DIAGNOSIS: Spinal cord lesion } \\
\text { ELIGIBLE: Not stated } \\
\text { ENROLLED: } 24 \\
\text { COMPLETED: } 24 \\
\text { AGE: Adults } \\
\text { GENDER: Female }\end{array}$} \\
\hline Interventions & \multicolumn{2}{|c|}{$\begin{array}{l}\text { Short length female catheter (hydrophilic coated) versus standard length (various designs) } \\
\text { female catheter }\end{array}$} \\
\hline Outcomes & \multicolumn{2}{|c|}{ Residual urine measured by ultrasound, satisfaction, handling, suitability of length } \\
\hline Notes & \multicolumn{2}{|c|}{ No difference in residual urine outcomes, satisfaction or ease of handling } \\
\hline \multicolumn{3}{|l|}{ Risk of bias } \\
\hline Bias & Authors' judgement & Support for judgement \\
\hline $\begin{array}{l}\text { Random sequence generation (selection } \\
\text { bias) }\end{array}$ & Low risk & $\begin{array}{l}\text { "Participants were randomised in blocks of } \\
\text { four" }\end{array}$ \\
\hline Allocation concealment (selection bias) & Unclear risk & Not stated \\
\hline $\begin{array}{l}\text { Blinding of participants and personnel } \\
\text { (performance bias) } \\
\text { All outcomes }\end{array}$ & Low risk & $\begin{array}{l}\text { "Single-blind". Not possible to blind par- } \\
\text { ticipants, but outcome assessment was } \\
\text { blinded and the non-blinding of partici- } \\
\text { pants was considered unlikely to introduce } \\
\text { bias }\end{array}$ \\
\hline $\begin{array}{l}\text { Blinding of outcome assessment (detection } \\
\text { bias) } \\
\text { All outcomes }\end{array}$ & Low risk & $\begin{array}{l}\text { "Study nurse (who carried out the ultra- } \\
\text { sound) was not present during the catheter- } \\
\text { ization in order to remain blinded regard- } \\
\text { ing the type of catheter used". partici- } \\
\text { pant-reported handling and satisfaction of }\end{array}$ \\
\hline
\end{tabular}

Intermittent catheterisation for long-term bladder management (Review) 
Biering-Sorensen 2007 (Continued)

catheter and was unblinded

\begin{tabular}{|c|c|c|}
\hline $\begin{array}{l}\text { Incomplete outcome data (attrition bias) } \\
\text { All outcomes }\end{array}$ & Low risk & No missing outcome data. \\
\hline Source of Funding & Unclear risk & Coloplast A/S \\
\hline \multicolumn{3}{|l|}{ Cardenas 2009} \\
\hline Methods & \multicolumn{2}{|c|}{$\begin{array}{l}\text { DESIGN: Randomised controlled trial } \\
\text { BLINDING PROCEDURES: Non-blinded } \\
\text { SAMPLE CALCULATION: Yes } \\
\text { DURATION: } 12 \text { months } \\
\text { WITHDRAWALS/DROPOUTS: } 11 \\
\text { ITT: Not stated } \\
\text { GEOGRAPHICAL LOCATION: North America } \\
\text { SETTING: Community }\end{array}$} \\
\hline Participants & \multicolumn{2}{|c|}{$\begin{array}{l}N=56 \\
\text { DIAGNOSIS: Spinal cord injury for }>6 \text { months with }>1 \text { UTI } \\
\text { ELIGIBLE: Not stated } \\
\text { ENROLLED: } 56 \\
\text { COMPLETED: } 45 \\
\text { AGE: Adults } \\
\text { GENDER: } 29 \text { male, } 16 \text { female }\end{array}$} \\
\hline
\end{tabular}

Interventions $\quad$ Hydrophilic-coated catheter, not activated, water added by user versus uncoated catheter, non-lubricated, single use both arms

\begin{tabular}{ll}
\hline Outcomes & Symptomatic UTI, treatment with antibiotics \\
\hline Notes & $\begin{array}{l}\text { No difference in incidence of bacteriuria or symptomatic UTIs between treatment and } \\
\text { control groups. Significantly less UTIs treated with antibiotics in treatment group }\end{array}$ \\
\hline
\end{tabular}

\section{Risk of bias}

\begin{tabular}{l|l|l}
\hline Bias & Authors' judgement & Support for judgement \\
\hline $\begin{array}{l}\text { Random sequence generation (selection } \\
\text { bias) }\end{array}$ & Unclear risk & $\begin{array}{l}\text { Not stated. More women in the control } \\
\text { group, significantly more tetraplegic partic- } \\
\text { ipants in the control group }\end{array}$ \\
\hline $\begin{array}{l}\text { Allocation concealment (selection bias) } \\
\text { Blinding of participants and personnel } \\
\text { (performance bias) } \\
\text { All outcomes }\end{array}$ & Lnclear risk & Not stated. \\
\hline
\end{tabular}

Intermittent catheterisation for long-term bladder management (Review)

Copyright @ 2014 The Cochrane Collaboration. Published by John Wiley \& Sons, Ltd. 
Cardenas 2009 (Continued)

\begin{tabular}{|c|c|c|}
\hline $\begin{array}{l}\text { Blinding of outcome assessment (detection } \\
\text { bias) } \\
\text { All outcomes }\end{array}$ & Unclear risk & $\begin{array}{l}\text { Unblinded. Monthly self-report of UTI } \\
\text { symptoms together with urine sampling } \\
\text { used to determine presence of UTI. Use } \\
\text { of antibiotics determined by participant's } \\
\text { clinician (independent of research trial) }\end{array}$ \\
\hline $\begin{array}{l}\text { Incomplete outcome data (attrition bias) } \\
\text { All outcomes }\end{array}$ & Low risk & $\begin{array}{l}\text { Missing outcome data balanced in num- } \\
\text { bers between intervention group }(n=6) \\
\text { and control group }(n=5) \text {, with similar rea- } \\
\text { sons for missing data across groups }\end{array}$ \\
\hline Source of Funding & Low risk & $\begin{array}{l}\text { National Institute on Disability and Reha- } \\
\text { bilitation Research US }\end{array}$ \\
\hline
\end{tabular}

Cardenas 2011

Methods

DESIGN: Randomised controlled trial

BLINDING PROCEDURES: Non-blinded

SAMPLE CALCULATION: Yes

DURATION: Up to 6 months

WITHDRAWALS/DROPOUTS: 110

ITT: Not stated

GEOGRAPHICAL LOCATION: North America

SETTING: Hospital and community

$\begin{array}{ll}\text { Participants } & \text { N }=224 \\ & \text { DIAGNOSIS: Spinal cord injury no longer than } 3 \text { months } \\ \text { ELIGIBLE: Not stated } & \text { ENROLLED: } 224 \\ \text { COMPLETED: } 114 \\ \text { AGE: Adults } \\ \text { GENDER: } 161 \text { male, } 39 \text { female (enrolled - did not state gender of numbers completing) }\end{array}$

Interventions

Hydrophilic-coated catheter, activated versus uncoated catheter, non-lubricated (single use both arms)

Outcomes

Time to 1st UTI; UTI incidence; microhaematuria measured at weeks 3 and 4; satisfaction measured at 45 days

Notes

Time to first antibiotic treated symptomatic UTI was significantly delayed in hydrophiliccoated catheter group. 14 reports of bleeding in hydrophilic and 6 reports in uncoated

\section{Risk of bias}

Bias
Authors' judgement
Support for judgement 


\section{Cardenas 2011 (Continued)}

\begin{tabular}{|c|c|c|}
\hline $\begin{array}{l}\text { Random sequence generation (selection } \\
\text { bias) }\end{array}$ & Low risk & $\begin{array}{l}\text { "A centralized computer-generated ran- } \\
\text { domization list was generated" }\end{array}$ \\
\hline Allocation concealment (selection bias) & Low risk & "Sealed envelopes were provided" \\
\hline $\begin{array}{l}\text { Blinding of participants and personnel } \\
\text { (performance bias) } \\
\text { All outcomes }\end{array}$ & Low risk & $\begin{array}{l}\text { "The inability to blind participants and } \\
\text { clinicians to the catheter type is a potential } \\
\text { limitation of the trial". Probably did not } \\
\text { create performance bias }\end{array}$ \\
\hline $\begin{array}{l}\text { Blinding of outcome assessment (detection } \\
\text { bias) } \\
\text { All outcomes }\end{array}$ & Unclear risk & $\begin{array}{l}\text { "The inability to blind participants and } \\
\text { clinicians to the catheter type is a potential } \\
\text { limitation of the trial". Outcome of UTI } \\
\text { was participant- and clinician-determined }\end{array}$ \\
\hline $\begin{array}{l}\text { Incomplete outcome data (attrition bias) } \\
\text { All outcomes }\end{array}$ & High risk & $\begin{array}{l}\text { "In the hydrophilic catheter group... many } \\
\text { of the investigational sites did not routinely } \\
\text { use hydrophilic catheters. The trial proto- } \\
\text { col did not include a number of training } \\
\text { catheterizations". A greater number of par- } \\
\text { ticipants dropped out in the hydrophilic- } \\
\text { coated group, resulting in incomplete out- } \\
\text { come data both for UTI, and participant } \\
\text { satisfaction, which did not appear to have } \\
\text { been measured in these participants }\end{array}$ \\
\hline Source of Funding & Unclear risk & Coloplast A/S \\
\hline
\end{tabular}

Chartier-Kastler 2011

Methods

DESIGN: Randomised controlled cross-over trial

BLINDING PROCEDURES: Not possible for participants. No blinding to investigator.

SAMPLE CALCULATION: Yes

DURATION: 14 days

WITHDRAWALS/DROPOUTS: 9 ( 5 in control arm, 4 in other arm)

ITT: Not applicable

GEOGRAPHICAL LOCATION: France/Denmark

SETTING: Hospital outpatient clinic

Participants N $=36$

DIAGNOSIS: Spinal cord lesion and normal/impaired urethral sensation

ELIGIBLE: 36

ENROLLED: 36

COMPLETED: 27

AGE: Adults

GENDER: Male 


\section{Chartier-Kastler 2011 (Continued)}

\begin{tabular}{|c|c|c|}
\hline Interventions & \multicolumn{2}{|c|}{$\begin{array}{l}\text { Short length male hydrophilic-coated (activated) catheter versus standard length male } \\
\text { hydrophilic-coated (activated) catheter }\end{array}$} \\
\hline Outcomes & \multicolumn{2}{|c|}{ Participant satisfaction and ease of use } \\
\hline Notes & \multicolumn{2}{|c|}{$\begin{array}{l}\text { No infection outcome. Significant difference in favour of the compact catheter. No } \\
\text { description of how the data were imputed, resulting in a potential risk of bias in favour } \\
\text { of non-inferiority }\end{array}$} \\
\hline \multicolumn{3}{|l|}{ Risk of bias } \\
\hline Bias & Authors' judgement & Support for judgement \\
\hline $\begin{array}{l}\text { Random sequence generation (selection } \\
\text { bias) }\end{array}$ & Low risk & $\begin{array}{l}\text { "Randomised to one of two treatment } \\
\text { groups by computer" }\end{array}$ \\
\hline Allocation concealment (selection bias) & Low risk & $\begin{array}{l}\text { "Sealed randomization envelopes were pro- } \\
\text { vided" }\end{array}$ \\
\hline $\begin{array}{l}\text { Blinding of participants and personnel } \\
\text { (performance bias) } \\
\text { All outcomes }\end{array}$ & Low risk & $\begin{array}{l}\text { No blinding, but the review authors judge } \\
\text { that the outcome and outcome measure- } \\
\text { ment are not likely to be influenced by lack } \\
\text { of blinding }\end{array}$ \\
\hline $\begin{array}{l}\text { Blinding of outcome assessment (detection } \\
\text { bias) } \\
\text { All outcomes }\end{array}$ & Unclear risk & $\begin{array}{l}\text { Participant-reported outcome - risk of de- } \\
\text { tection bias unclear }\end{array}$ \\
\hline $\begin{array}{l}\text { Incomplete outcome data (attrition bias) } \\
\text { All outcomes }\end{array}$ & Unclear risk & $\begin{array}{l}\text { Flowchart to report participant dropout } \\
\text { presented, but no information to report } \\
\text { how data handled in the analysis, particu- } \\
\text { larly regarding imputation }\end{array}$ \\
\hline Source of Funding & Unclear risk & Coloplast A/S \\
\hline
\end{tabular}

Chartier-Kastler 2013

Methods

DESIGN: Randomised controlled cross-over trial

BLINDING PROCEDURES: Non-blinded

SAMPLE CALCULATION: Yes

DURATION: 12 weeks

WITHDRAWALS/DROPOUTS: 6

ITT: Not applicable

GEOGRAPHICAL LOCATION: France, Germany, Norway, Sweden, Denmark

SETTING: Hospitals, clinics, research centres 


\section{Chartier-Kastler 2013 (Continued)}

\begin{tabular}{|c|c|c|}
\hline Participants & \multicolumn{2}{|c|}{$\begin{array}{l}\text { N = } 106 \\
\text { DIAGNOSIS: Neurogenic bladder disfunction, various } \\
\text { ELIGIBLE: } 125 \\
\text { ENROLLED: } 125 \\
\text { COMPLETED: } 106 \\
\text { AGE: Adults } \\
\text { GENDER: Male and female }\end{array}$} \\
\hline Interventions & \multicolumn{2}{|c|}{ Shorter versus longer catheter (both hydrophilic) } \\
\hline Outcomes & \multicolumn{2}{|c|}{ ISC-Q score and user preference } \\
\hline Notes & \multicolumn{2}{|c|}{ Preference for shorter length catheter. Domain scores for ISC-Q not reported } \\
\hline \multicolumn{3}{|l|}{ Risk of bias } \\
\hline Bias & Authors' judgement & Support for judgement \\
\hline $\begin{array}{l}\text { Random sequence generation (selection } \\
\text { bias) }\end{array}$ & Low risk & $\begin{array}{l}\text { "patients were allocated to the treatment } \\
\text { sequence by randomization of numbers in } \\
\text { sealed identical and non-transparent en- } \\
\text { velopes" }\end{array}$ \\
\hline Allocation concealment (selection bias) & Low risk & $\begin{array}{l}\text { "patients were allocated to the treatment } \\
\text { sequence by randomization of numbers in } \\
\text { sealed identical and non-transparent en- } \\
\text { velopes" }\end{array}$ \\
\hline $\begin{array}{l}\text { Blinding of participants and personnel } \\
\text { (performance bias) } \\
\text { All outcomes }\end{array}$ & Low risk & $\begin{array}{l}\text { No blinding, but the review authors judge } \\
\text { that the outcome and outcome measure- } \\
\text { ment are not likely to be influenced by lack } \\
\text { of blinding }\end{array}$ \\
\hline $\begin{array}{l}\text { Blinding of outcome assessment (detection } \\
\text { bias) } \\
\text { All outcomes }\end{array}$ & Unclear risk & $\begin{array}{l}\text { User preference, so not possible to blind } \\
\text { outcome assessment }\end{array}$ \\
\hline $\begin{array}{l}\text { Incomplete outcome data (attrition bias) } \\
\text { All outcomes }\end{array}$ & Unclear risk & $\begin{array}{l}19 \text { enrolled participants did not complete } \\
\text { all data collection }\end{array}$ \\
\hline Source of Funding & Unclear risk & Coloplast A/S \\
\hline
\end{tabular}


Methods

DESIGN: Randomised controlled cross-over trial

BLINDING PROCEDURES: None

SAMPLE CALCULATION: No

DURATION: Use of 10 catheter sets for each arm of trial

FOLLOW-UP: No

WITHDRAWALS/DROPOUTS:9

ITT: Not applicable

GEOGRAPHICAL LOCATION: 7 sites, US

SETTING: Not stated

\begin{tabular}{ll} 
Participants & N $=81$ \\
& DIAGNOSIS: Paraplegic with neuropathic voiding dysfunction \\
& ELIGIBLE: Not stated \\
& ENROLLED: 91 \\
& $\begin{array}{l}\text { COMPLETED: 82, although } 23 \text { of these did not fully complete test arm } \\
\text { AGE: Adults } \\
\text { GENDER: Male }\end{array}$ \\
\hline Interventions & $\begin{array}{l}\text { Standard length catheter versus shorter length catheter (uncoated, pre-lubricated closed } \\
\text { system with integrated collection bag both arms) }\end{array}$ \\
\hline Outcomes & $\begin{array}{l}\text { User preference for catheter length (standard versus shorter length), ease of use, sensation } \\
\text { of emptying }\end{array}$ \\
\hline Notes & $\begin{array}{l}\text { Preference for standard (longer length) catheter. Most common reason for preference } \\
\text { was perception of complete bladder emptying }\end{array}$
\end{tabular}

\section{Risk of bias}

\begin{tabular}{|c|c|c|}
\hline Bias & Authors' judgement & Support for judgement \\
\hline $\begin{array}{l}\text { Random sequence generation (selection } \\
\text { bias) }\end{array}$ & Unclear risk & 'Randomisation was balanced to site'. \\
\hline Allocation concealment (selection bias) & Unclear risk & Not stated \\
\hline $\begin{array}{l}\text { Blinding of participants and personnel } \\
\text { (performance bias) } \\
\text { All outcomes }\end{array}$ & Low risk & $\begin{array}{l}\text { No blinding, but the review authors judge } \\
\text { that the outcome and outcome measure- } \\
\text { ment are not likely to be influenced by lack } \\
\text { of blinding }\end{array}$ \\
\hline $\begin{array}{l}\text { Blinding of outcome assessment (detection } \\
\text { bias) } \\
\text { All outcomes }\end{array}$ & Unclear risk & $\begin{array}{l}\text { User preference, so not possible to blind } \\
\text { outcome assessment }\end{array}$ \\
\hline $\begin{array}{l}\text { Incomplete outcome data (attrition bias) } \\
\text { All outcomes }\end{array}$ & Unclear risk & $\begin{array}{l}23 \text { of } 82 \text { participants were unable to com- } \\
\text { plete use of all } 10 \text { test catheters (shorter } \\
\text { length) due to inadequate bladder drainage }\end{array}$ \\
\hline
\end{tabular}


Costa 2013 (Continued)

\begin{tabular}{|c|c|c|}
\hline Source of Funding & Unclear risk & Hollister \\
\hline
\end{tabular}

Day 2003

\begin{tabular}{ll}
\hline Methods & DESIGN: Randomised controlled trial \\
& BLINDING PROCEDURES: Not stated \\
& SAMPLE CALCULATION: No (feasibility trial) \\
& DURATION: 24 hours \\
& FOLLOW-UP: 3 urine samples for C\&S in 24 hours \\
& WITHDRAWALS/DROPOUTS: No \\
& ITT: Not stated \\
& GEOGRAPHICAL LOCATION: Canada \\
& SETTING: ICU \\
\hline \multirow{3}{*}{ Participants } & N $=11$ \\
DIAGNOSIS: Neurogenic bladder due to recent spinal cord injury \\
ELIGIBLE: 53 \\
ENROLLED: 11 \\
COMPLETED: 11 \\
AGE: Adults \\
GENDER: Male \\
\hline
\end{tabular}

Interventions

Uncoated, pre-lubricated catheter with an integrated bag with an uncoated, non-lubricated catheter, aseptic technique both arms

Outcomes

3 urine samples for culture over a 24-hour period + meatal swabs

Notes

No difference between groups but sample too small and time frame too short to make any inferences

\section{Risk of bias}

\begin{tabular}{l|l|l}
\hline Bias & Authors judgement & Support for judgement \\
\hline $\begin{array}{l}\text { Random sequence generation (selection } \\
\text { bias) }\end{array}$ & Unclear risk & Not stated \\
\hline $\begin{array}{l}\text { Allocation concealment (selection bias) } \\
\begin{array}{l}\text { Blinding of participants and personnel } \\
\text { (performance bias) } \\
\text { All outcomes }\end{array}\end{array}$ & Low risk & Not stated \\
\hline
\end{tabular}

Blinding of outcome assessment (detection Unclear risk bias)

All outcomes

Not stated

Intermittent catheterisation for long-term bladder management (Review) 
Day 2003 (Continued)

\begin{tabular}{|c|c|c|}
\hline $\begin{array}{l}\text { Incomplete outcome data (attrition bias) } \\
\text { All outcomes }\end{array}$ & Low risk & No missing outcome data \\
\hline Source of Funding & Unclear risk & Not stated. \\
\hline \multicolumn{3}{|l|}{ De Ridder 2005} \\
\hline Methods & \multicolumn{2}{|c|}{$\begin{array}{l}\text { DESIGN: Randomised controlled trial } \\
\text { BLINDING PROCEDURES: Not stated } \\
\text { SAMPLE CALCULATION: Yes } \\
\text { DURATION: } 12 \text { months } \\
\text { FOLLOW-UP: Baseline, day } 15 \text { then monthly x } 12 \text { months } \\
\text { WITHDRAWALS/DROPOUTS: } 66 \\
\text { ITT: Not stated } \\
\text { GEOGRAPHICAL LOCATION: Europe } \\
\text { SETTING: Rehabilitation and community }\end{array}$} \\
\hline Participants & $\begin{array}{l}\mathrm{N}=123 \\
\text { DIAGNOSIS: Neurogenic bladder due to } \\
\text { ELIGIBLE: Unknown } \\
\text { ENROLLED: } 123 \\
\text { COMPLETED: } 57 \\
\text { AGE: Adults } \\
\text { GENDER: Male }\end{array}$ & pinal cord injury $<6$ months \\
\hline
\end{tabular}

Interventions

Hydrophilic-coated catheter, activated versus uncoated catheter, non-lubricated (single use both arms); assessed at Day 15 then monthly x $12 \mathrm{~m}$

\begin{tabular}{ll} 
Outcomes & $\begin{array}{l}\text { Primary: UTI } \\
\text { Secondary: haematuria strictures, convenience; 82\% PVC had UTI; 64\% Speedicath; } \\
\text { no difference in haematuria }\end{array}$ \\
\hline Notes & $\begin{array}{l}\text { UTI described as "clinical infection with Sx of UTI and for which treatment was pre- } \\
\text { scribed", however, lab analyses did not differ between groups. significant challenges in } \\
\text { retaining participants illustrating the difficulty of conducting trials in this group }\end{array}$
\end{tabular}

Risk of bias

\begin{tabular}{|c|c|c|}
\hline Bias & Authors' judgement & Support for judgement \\
\hline $\begin{array}{l}\text { Random sequence generation (selection } \\
\text { bias) }\end{array}$ & Unclear risk & "Patients were randomised in two groups" \\
\hline Allocation concealment (selection bias) & Unclear risk & Not stated \\
\hline $\begin{array}{l}\text { Blinding of participants and personnel } \\
\text { (performance bias) } \\
\text { All outcomes }\end{array}$ & Low risk & $\begin{array}{l}\text { No blinding, but the review authors judge } \\
\text { that the outcome and outcome measure- } \\
\text { ment are not likely to be influenced by lack }\end{array}$ \\
\hline
\end{tabular}

Intermittent catheterisation for long-term bladder management (Review)

Copyright (๑) 2014 The Cochrane Collaboration. Published by John Wiley \& Sons, Ltd. 
De Ridder 2005 (Continued)

of blinding

\begin{tabular}{l|l|l}
\hline $\begin{array}{l}\text { Blinding of outcome assessment (detection } \\
\text { bias) } \\
\text { All outcomes }\end{array}$ & Low risk & $\begin{array}{l}\text { Not stated, but outcome not likely to be } \\
\text { influenced by a lack of blinding }\end{array}$ \\
\hline $\begin{array}{l}\text { Incomplete outcome data (attrition bias) } \\
\text { All outcomes }\end{array}$ & High risk & $\begin{array}{l}\text { Outcome data accounted for descriptively. } \\
\text { However, larger numbers of dropouts in } \\
\text { intervention group. This has not been ac- } \\
\text { counted for in the analysis, which does not } \\
\text { appear to be intention-to-treat }\end{array}$ \\
\hline Source of Funding & Unclear risk & Not stated. \\
\hline
\end{tabular}

Denys 2012

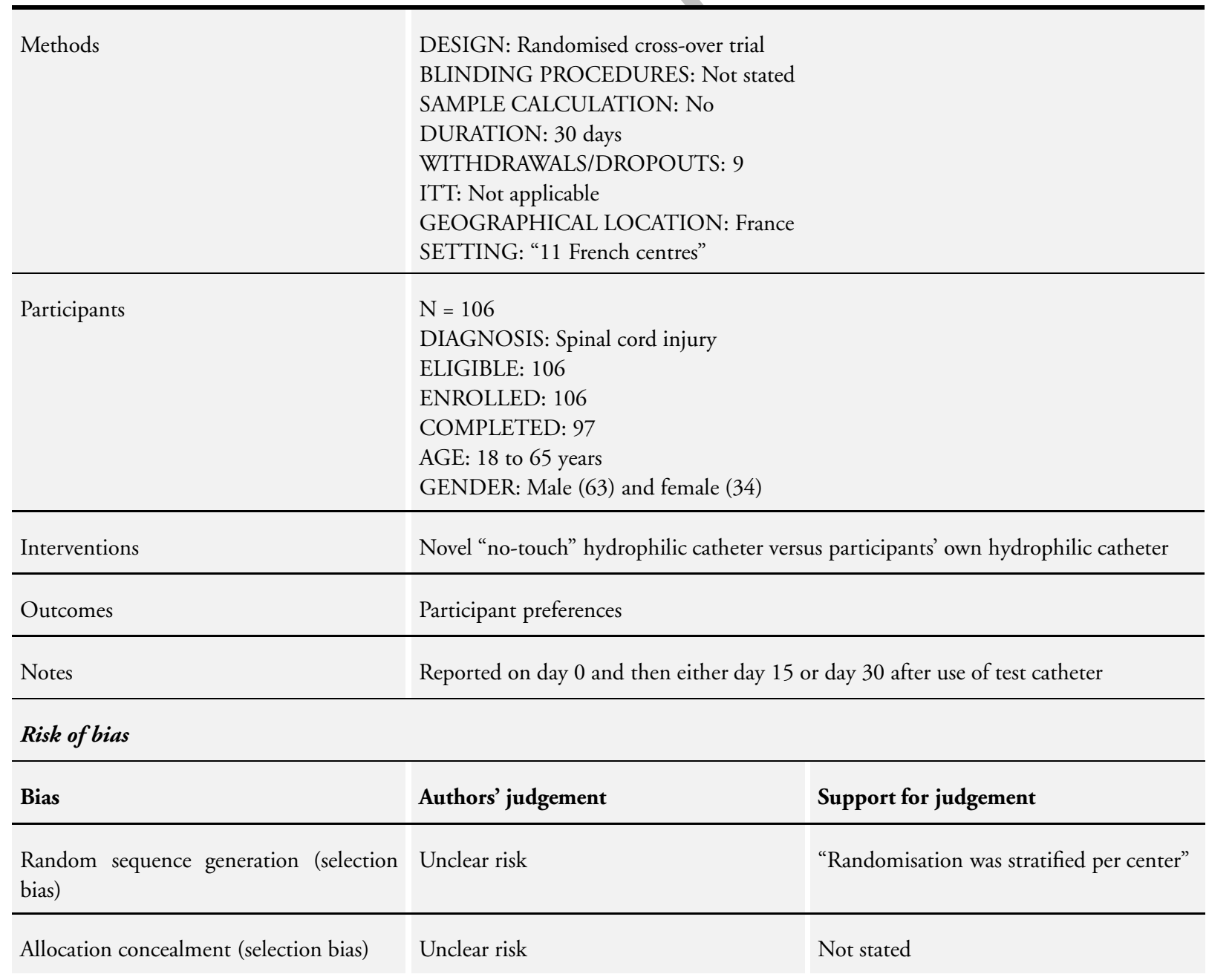

Intermittent catheterisation for long-term bladder management (Review) 


\section{Denys 2012 (Continued)}

Blinding of participants and personnel Low risk (performance bias)

All outcomes

Blinding of outcome assessment (detection Unclear risk bias)

All outcomes

Incomplete outcome data (attrition bias) Low risk

All outcomes

Source of Funding

Unclear risk
No blinding, but the review authors judge that the outcome and outcome measurement are not likely to be influenced by lack of blinding

Not stated

Missing outcome data balanced in numbers between intervention group $(n=4)$ and control group $(n=5)$, with similar reasons for dropout across groups

Hollister France Inc.

Domurath 2011

\begin{tabular}{|c|c|c|}
\hline Methods & \multicolumn{2}{|c|}{$\begin{array}{l}\text { DESIGN: Randomised controlled cross-over trial } \\
\text { BLINDING PROCEDURES: Single blind (trial nurse) } \\
\text { SAMPLE CALCULATION: Yes } \\
\text { DURATION: } 1 \text { day } \\
\text { WITHDRAWALS/DROPOUTS: } 1 \\
\text { ITT: Not applicable } \\
\text { GEOGRAPHICAL LOCATION: Three trial sites in Germany } \\
\text { SETTING: Not stated }\end{array}$} \\
\hline Participants & \multicolumn{2}{|c|}{$\begin{array}{l}\mathrm{N}=37 \\
\text { DIAGNOSIS: Spinal cord injury } \\
\text { ELIGIBLE: } 37 \\
\text { ENROLLED: } 37 \\
\text { COMPLETED: } 36 \\
\text { AGE: Adults } \\
\text { GENDER: Male }\end{array}$} \\
\hline Interventions & \multicolumn{2}{|c|}{$\begin{array}{l}\text { Short length male hydrophilic-coated catheter (activated) versus standard length male } \\
\text { hydrophilic-coated catheter (activated) }\end{array}$} \\
\hline Outcomes & \multicolumn{2}{|c|}{ Residual urine and user satisfaction } \\
\hline Notes & \multicolumn{2}{|c|}{ Two observations of visible bleeding on test catheter } \\
\hline \multicolumn{3}{|l|}{ Risk of bias } \\
\hline Bias & Authors' judgement & Support for judgement \\
\hline $\begin{array}{l}\text { Random sequence generation (selection } \\
\text { bias) }\end{array}$ & Low risk & $\begin{array}{l}\text { "Crossover design, randomized in per- } \\
\text { muted blocks" }\end{array}$ \\
\hline
\end{tabular}




\section{Domurath 2011 (Continued)}

\begin{tabular}{|c|c|c|}
\hline Allocation concealment (selection bias) & Unclear risk & Not stated \\
\hline $\begin{array}{l}\text { Blinding of participants and personnel } \\
\text { (performance bias) } \\
\text { All outcomes }\end{array}$ & Low risk & $\begin{array}{l}\text { No blinding of participants, but risk of per- } \\
\text { formance bias considered low as cross-over } \\
\text { trial. Blinding of trial nurse throughout all } \\
\text { measurement procedures }\end{array}$ \\
\hline $\begin{array}{l}\text { Blinding of outcome assessment (detection } \\
\text { bias) } \\
\text { All outcomes }\end{array}$ & Unclear risk & $\begin{array}{l}\text { Participant-reported outcome - risk of de- } \\
\text { tection bias unclear }\end{array}$ \\
\hline $\begin{array}{l}\text { Incomplete outcome data (attrition bias) } \\
\text { All outcomes }\end{array}$ & Unclear risk & $\begin{array}{l}1 \text { withdrawal reported because the partic- } \\
\text { ipant "did not consider the 'test' catheter } \\
\text { material flexible enough" }\end{array}$ \\
\hline Source of Funding & Unclear risk & Coloplast A/S. \\
\hline \multicolumn{3}{|l|}{ Duffy 1995} \\
\hline Methods & \multicolumn{2}{|c|}{$\begin{array}{l}\text { DESIGN: Randomised controlled trial } \\
\text { ALLOCATION: Not described but did stratify participants according to presence/ ab- } \\
\text { sence of UTI and trial site. } \\
\text { BLINDING PROCEDURES: Unclear } \\
\text { SAMPLE CALCULATION: Yes post hoc } \\
\text { DURATION: } 3 \text { months } \\
\text { FOLLOW-UP: days 2, 4, } 6,10,15,60 \& 90 \\
\text { WITHDRAWALS/DROPOUTS: } 2 \\
\text { ITT: Not stated } \\
\text { GEOGRAPHICAL LOCATION: USA } \\
\text { SETTING: } 3 \text { long-term care Veterans Administration Medical Centre Nursing Homes }\end{array}$} \\
\hline Participants & \multicolumn{2}{|c|}{$\begin{array}{l}\text { N = } 80 \\
\text { DIAGNOSIS: Incomplete bladder emptying due to prostate obstruction } \\
\text { ELIGIBLE: } 203 \\
\text { ENROLLED: } 82 \\
\text { COMPLETED: } 80 \text { to day } 15 ; 39 \text { completed to Day 90) } \\
\text { AGE: Elderly } \\
\text { GENDER: Male }\end{array}$} \\
\hline
\end{tabular}

Interventions

Sterile technique vs clean technique (also single vs multiple use): sterile equipment and procedure, cleaning with betadine; Clean technique: catheter washed with soap and water and reused x 1 week (uncoated, non-lubricated catheters)

Outcomes

Number of treatment episodes for UTI + urinalysis.

Notes

Some participants had indwelling catheters prior to enrolment in the trial (not stated how many); weeks to onset of symptomatic UTI was 3.11 (3.12) for treatment and 3.5 (3.02) for control. Dropout rate high after Day 15 with only 39 completing data 
Duffy 1995 (Continued)

collection to Day 90

\section{Risk of bias}

\begin{tabular}{|c|c|c|}
\hline Bias & Authors' judgement & Support for judgement \\
\hline $\begin{array}{l}\text { Random sequence generation (selection } \\
\text { bias) }\end{array}$ & Unclear risk & "Randomly assigned" \\
\hline Allocation concealment (selection bias) & Unclear risk & Not stated \\
\hline $\begin{array}{l}\text { Blinding of participants and personnel } \\
\text { (performance bias) } \\
\text { All outcomes }\end{array}$ & Low risk & $\begin{array}{l}\text { No blinding, but the review authors judge } \\
\text { that the outcome and outcome measure- } \\
\text { ment are not likely to be influenced by lack } \\
\text { of blinding }\end{array}$ \\
\hline $\begin{array}{l}\text { Blinding of outcome assessment (detection } \\
\text { bias) } \\
\text { All outcomes }\end{array}$ & Unclear risk & $\begin{array}{l}\text { No blinding of outcome assessment - this } \\
\text { may have resulted in bias }\end{array}$ \\
\hline $\begin{array}{l}\text { Incomplete outcome data (attrition bias) } \\
\text { All outcomes }\end{array}$ & Unclear risk & $\begin{array}{l}\text { All participants had full dataset for Day } 15 \text {, } \\
\text { but missing outcome data at end of } 90 \text { days }\end{array}$ \\
\hline Source of Funding & Low risk & Dept of Veterans Affairs US. \\
\hline
\end{tabular}

Fader 2001

Methods

DESIGN: Randomised controlled cross-over trial

BLINDING PROCEDURES:

SAMPLE CALCULATION: Yes

DURATION: 1 week for each of 4 arms

WITHDRAWALS/DROPOUTS: None

ITT: Not applicable

GEOGRAPHICAL LOCATION: UK

SETTING: 7 test centres run by continence nurse specialists

\begin{tabular}{ll}
\hline Participants & N $=61$ \\
& DIAGNOSIS: not stated \\
& ELIGIBLE: Not stated \\
& ENROLLED: 61 \\
& COMPLETED: 61 \\
& AGE: Adults \\
& GENDER: Male \\
\hline Interventions & Comparison of 4 hydrophilic-coated catheters (not activated, water added by user) \\
\hline Outcomes & Smoothness of catheter removal, severity of sticking and user-reported satisfaction and \\
& ease of use
\end{tabular}


Fader 2001 (Continued)

Notes

Risk of bias

\begin{tabular}{|c|c|c|}
\hline Bias & Authors' judgement & Support for judgement \\
\hline $\begin{array}{l}\text { Random sequence generation (selection } \\
\text { bias) }\end{array}$ & Low risk & "Randomisation in Latin squares" \\
\hline Allocation concealment (selection bias) & Unclear risk & Not stated \\
\hline $\begin{array}{l}\text { Blinding of participants and personnel } \\
\text { (performance bias) } \\
\text { All outcomes }\end{array}$ & Low risk & $\begin{array}{l}\text { No blinding, but the review authors judge } \\
\text { that the outcome and outcome measure- } \\
\text { ment are not likely to be influenced by lack } \\
\text { of blinding }\end{array}$ \\
\hline $\begin{array}{l}\text { Blinding of outcome assessment (detection } \\
\text { bias) } \\
\text { All outcomes }\end{array}$ & Low risk & $\begin{array}{l}\text { Participant-reported outcome, but risk of } \\
\text { detection bias considered low as cross-over } \\
\text { trial }\end{array}$ \\
\hline $\begin{array}{l}\text { Incomplete outcome data (attrition bias) } \\
\text { All outcomes }\end{array}$ & Unclear risk & Not stated \\
\hline Source of Funding & Low risk & Continence Product Evaluation Network. \\
\hline
\end{tabular}

Fera 2002

Methods

DESIGN: Randomised controlled trial BLINDING PROCEDURES: Unclear SAMPLE CALCULATION: No

DURATION: 4 months

FOLLOW-UP: Urine culture every 3 weeks for 4 months (5 samples)

WITHDRAWALS/DROPOUTS: 0

ITT: Not stated

GEOGRAPHICAL LOCATION: Brazil

SETTING: General School Hospital

\begin{tabular}{ll} 
Participants & N $=20$ \\
& DIAGNOSIS: Variable, mielomeningocele most common $(25 \%)$ \\
& ELIGIBLE: Not stated \\
& ENROLLED: 20 \\
& COMPLETED: 20 \\
& AGE: Mixed adults and children 2-79 years (mean not stated) \\
& GENDER: 12 male and 8 female \\
\hline Interventions & Other strategies designed to reduce infection: Gentamycin cream $(0.1 \%)$ versus lidocaine \\
& jelly used as separate lubricant for IC
\end{tabular}

Intermittent catheterisation for long-term bladder management (Review) 
Fera 2002 (Continued)

\begin{tabular}{ll}
\hline Outcomes & $\begin{array}{l}\text { Number of episodes of asymptomatic bacteriuria }(>=100,000 \mathrm{CFU} / \mathrm{mL}), \text { number of } \\
\text { participants with symptomatic UTI }\end{array}$ \\
\hline Notes & $\begin{array}{l}\text { Repeated measures of asymptomatic bacteriuria reported for each participant. Final mea- } \\
\text { sure used in table of results. Asymptomatic bacteriuria similar in both groups } 8 / 10 \text { in } \\
\text { gentamycin group } 6 / 10 \text { in lidocaine group. } 1 / 10 \text { developed symptomatic UTI in gen- } \\
\text { tamycin group, } 2 / 10 \text { in Lidocaine group }\end{array}$ \\
\hline
\end{tabular}

\section{Risk of bias}

\begin{tabular}{|c|c|c|}
\hline Bias & Authors' judgement & Support for judgement \\
\hline $\begin{array}{l}\text { Random sequence generation (selection } \\
\text { bias) }\end{array}$ & Unclear risk & "Patients were randomised in two groups" \\
\hline Allocation concealment (selection bias) & Unclear risk & Not stated \\
\hline $\begin{array}{l}\text { Blinding of participants and personnel } \\
\text { (performance bias) } \\
\text { All outcomes }\end{array}$ & Low risk & $\begin{array}{l}\text { No blinding, but the review authors judge } \\
\text { that the outcome and outcome measure- } \\
\text { ment are not likely to be influenced by lack } \\
\text { of blinding }\end{array}$ \\
\hline
\end{tabular}

Blinding of outcome assessment (detection Low risk

Not stated, but outcome not likely to be bias) influenced by a lack of blinding

All outcomes

\begin{tabular}{lll}
\hline Incomplete outcome data (attrition bias) & Low risk & No missing outcome data
\end{tabular}
All outcomes

\begin{tabular}{lll}
\hline Source of Funding & Unclear risk & Not stated
\end{tabular}

Giannantoni 2001

Methods 
Giannantoni 2001 (Continued)

AGE: Adults

GENDER: 16 male $\& 2$ female

Interventions

Coated vs uncoated: Pre-lubricated catheter with protective sleeve versus an uncoated, non-lubricated catheter (water added by user); one catheter $\mathrm{x} 7$ weeks then cross-over to other group

Outcomes

UTI measured by C\&S at 2, 4 \& 7 weeks;

Urethral wall trauma by counting cells on catheter surface; VAS re: satisfaction with catheters

Notes

UTI defined as cloudy, odorous urine, onset of UI, increase autonomic dysreflexia, pyuria, bacteriuria; Sample size too small to draw conclusions.

Attempted randomisation concealment; higher \% of UTI in PVC group; no difference in urethral cell count; unable to use data in Table of Comparisons because of cross-over design and no mid-point data

\section{Risk of bias}

\begin{tabular}{|c|c|c|}
\hline Bias & Authors' judgement & Support for judgement \\
\hline $\begin{array}{l}\text { Random sequence generation (selection } \\
\text { bias) }\end{array}$ & Unclear risk & "One of us organised randomisation" \\
\hline Allocation concealment (selection bias) & Unclear risk & Not stated \\
\hline $\begin{array}{l}\text { Blinding of participants and personnel } \\
\text { (performance bias) } \\
\text { All outcomes }\end{array}$ & Low risk & $\begin{array}{l}\text { No blinding, but the review authors judge } \\
\text { that the outcome and outcome measure- } \\
\text { ment are not likely to be influenced by lack } \\
\text { of blinding }\end{array}$ \\
\hline $\begin{array}{l}\text { Blinding of outcome assessment (detection } \\
\text { bias) } \\
\text { All outcomes }\end{array}$ & Unclear risk & $\begin{array}{l}\text { Insufficient information to permit judge- } \\
\text { ment }\end{array}$ \\
\hline $\begin{array}{l}\text { Incomplete outcome data (attrition bias) } \\
\text { All outcomes }\end{array}$ & Low risk & No missing outcome data \\
\hline Source of Funding & Unclear risk & Not stated \\
\hline
\end{tabular}




Dethods
BLINDING PROAdomised controlled trial
SAMPLE CALCULATION: No
DURATION: 28 days
FOLLOW-UP: Daily urine dipslides
WITHDRAWALS/DROPOUTS: 11
ITT: Not stated
GEOGRAPHICAL LOCATION: USA
SETTING: Rehabilitation Hospital

\begin{tabular}{|c|c|}
\hline Participants & $\begin{array}{l}\mathrm{N}=46 \\
\text { DIAGNOSIS: Neurogenic bladder due to recent spinal cord injury } \\
\text { ELIGIBLE: } 58 \\
\text { ENROLLED: } 46 \\
\text { COMPLETED: } 35 \\
\text { AGE: Adults } \\
\text { GENDER: Male }\end{array}$ \\
\hline Interventions & $\begin{array}{l}\text { Sterile vs clean technique (also Single Use vs Multiple Use) catheterisation kit and sterile } \\
\text { single-use catheter, meatus cleansed with povidone iodine. } \\
\text { Clean technique: sterile catheter reused for one day after being washed with soap and } \\
\text { water, non-sterile gloves and container (uncoated, non-lubricated catheters) }\end{array}$ \\
\hline Outcomes & Ddaily urine dipslides + symptomatic UTI \\
\hline Notes & $\begin{array}{l}\text { No statistically significant differences between urine cultures or Sx UTI; weeks to onset } \\
\text { of UTI was } 1.1(0.87) \text { for treatment and } 1.2(1.0) \text { for control. Number of days in trial } \\
\text { varied from } 1 \text { to } 28 \text { with only nine participants completing more than twenty days }\end{array}$ \\
\hline
\end{tabular}

\section{Risk of bias}

\begin{tabular}{l|ll}
\hline Bias & Authors' judgement & Support for judgement \\
\hline $\begin{array}{l}\text { Random sequence generation (selection } \\
\text { bias) }\end{array}$ & Unclear risk & "46 patients were assigned randomly" \\
\hline Allocation concealment (selection bias) & Unclear risk & Not stated \\
\hline
\end{tabular}

Blinding of participants and personnel Low risk (performance bias)

All outcomes

Blinding of outcome assessment (detection Unclear risk bias)

All outcomes

Incomplete outcome data (attrition bias) Low risk All outcomes
No blinding, but the review authors judge that the outcome and outcome measurement are not likely to be influenced by lack of blinding

Not stated. UTI determined by lab results and participant symptoms

Withdrawals were evenly balanced between groups 
King 1992 (Continued)

\begin{tabular}{|c|c|c|}
\hline Source of Funding & Low risk & $\begin{array}{l}\text { American Association of Spinal Cord In- } \\
\text { jury Nurses; Rehabilitation Institute Foun- } \\
\text { dation US }\end{array}$ \\
\hline
\end{tabular}

Leek 2013

Methods

DESIGN: Randomised controlled cross-over trial

BLINDING PROCEDURES: 'Full blinding not possible, but microbiological data were entered by blinded staff'

SAMPLE CALCULATION: Yes

DURATION:16 weeks (8 weeks per arm)

WITHDRAWALS/DROPOUTS: 3 participants dropped out

ITT: Not applicable

GEOGRAPHICAL LOCATION: Australia

SETTING: Hospital outpatient pelvic floor clinic

\begin{tabular}{ll}
\hline Participants & N $=23$ \\
& DIAGNOSIS: Varied \\
& ELIGIBLE: 41 \\
& ENROLLED: 23 \\
COMPLETED: 20 \\
AGE: Adults \\
GENDER: 6 male, 17 female \\
\hline
\end{tabular}

Interventions

Uncoated catheter, non-lubricated and clean technique both arms

\begin{tabular}{l|l} 
Outcomes & Asymptomatic and symptomatic UTI with microbiological confirmation \\
\hline Notes & No statistically significant difference in the rate of symptomatic UTI at week 8 or 16
\end{tabular}

Risk of bias

\begin{tabular}{l|l|l}
\hline Bias & Authors' judgement & Support for judgement \\
\hline $\begin{array}{l}\text { Random sequence generation (selection } \\
\text { bias) }\end{array}$ & Low risk & 'Computer-generated randomisation code' \\
\hline $\begin{array}{l}\text { Allocation concealment (selection bias) } \\
\text { Low risk }\end{array}$ & Low sequentially numbered sealed en- \\
\hline
\end{tabular}

Blinding of participants and personnel Low risk (performance bias)

All outcomes

'Full blinding not possible, but microbiological data entered by blinded staff'. Risk of performance bias considered low as cross-over trial

Blinding of outcome assessment (detection Low risk bias)

Risk of detection bias considered low as All outcomes cross-over trial.

Intermittent catheterisation for long-term bladder management (Review)

Copyright @ 2014 The Cochrane Collaboration. Published by John Wiley \& Sons, Ltd. 
Leek 2013 (Continued)

\begin{tabular}{|c|c|c|}
\hline $\begin{array}{l}\text { Incomplete outcome data (attrition bias) } \\
\text { All outcomes }\end{array}$ & Unclear risk & Incomplete data for 3 participants \\
\hline Source of Funding & Unclear risk & Not stated \\
\hline \multicolumn{3}{|l|}{ Leriche 2006} \\
\hline Methods & \multicolumn{2}{|c|}{$\begin{array}{l}\text { DESIGN: Randomised controlled cross-over trial } \\
\text { BLINDING PROCEDURES: None } \\
\text { SAMPLE CALCULATION: Not reported } \\
\text { DURATION: Use of } 20 \text { sets of each product } \\
\text { FOLLOW-UP: } \\
\text { WITHDRAWALS/DROPOUTS: } 2 \\
\text { ITT: Not applicable } \\
\text { GEOGRAPHICAL LOCATION: France } \\
\text { SETTING: Hospital }\end{array}$} \\
\hline Participants & $\begin{array}{l}\text { N }=31 \\
\text { DIAGNOSIS: Vesico-sphincteric problem o } \\
\text { ELIGIBLE: Not stated } \\
\text { ENROLLED: } 31 \\
\text { COMPLETED: } 29 \\
\text { AGE: Adults } \\
\text { GENDER: Male }\end{array}$ & of neurological origin \\
\hline
\end{tabular}

Interventions

Hydrophilic-coated activated catheter with integrated bag versus uncoated, pre-lubricated catheter with integrated bag (aseptic technique, single use both arms)

Outcomes Product evaluation questionnaire and overall preference questionnaire

Notes $\quad$ Marked preference reported in favour of test catheter

\section{Risk of bias}

\begin{tabular}{l|ll}
\hline Bias & Authors' judgement & Support for judgement \\
\hline $\begin{array}{l}\text { Random sequence generation (selection } \\
\text { bias) }\end{array}$ & Low risk & $\begin{array}{l}\text { Using a computer random number gener- } \\
\text { ator }\end{array}$ \\
\hline $\begin{array}{l}\text { Allocation concealment (selection bias) } \\
\text { Blinding of participants and personnel } \\
\text { (performance bias) } \\
\text { All outcomes }\end{array}$ & Low risk & Not stated \\
\hline & & $\begin{array}{l}\text { No blinding, but the review authors judge } \\
\text { that the outcome and outcome measure- } \\
\text { ment are not likely to be influenced by lack } \\
\text { of blinding }\end{array}$
\end{tabular}


Leriche 2006 (Continued)

\begin{tabular}{|c|c|c|}
\hline $\begin{array}{l}\text { Blinding of outcome assessment (detection } \\
\text { bias) } \\
\text { All outcomes }\end{array}$ & Low risk & $\begin{array}{l}\text { Participant-reported outcome, but risk of } \\
\text { detection bias considered low as cross-over } \\
\text { trial }\end{array}$ \\
\hline $\begin{array}{l}\text { Incomplete outcome data (attrition bias) } \\
\text { All outcomes }\end{array}$ & Low risk & $\begin{array}{l}\text { Missing outcome data from } 2 \text { participants - } \\
\text { withdrawals described as not being related } \\
\text { to the trial }\end{array}$ \\
\hline Source of Funding & Unclear risk & Les Laboratoires Coloplast \\
\hline \multicolumn{3}{|l|}{ Mauroy 2001} \\
\hline Methods & \multicolumn{2}{|c|}{$\begin{array}{l}\text { DESIGN: Randomised controlled cross-over trial } \\
\text { BLINDING PROCEDURES: Yes } \\
\text { SAMPLE CALCULATION: No } \\
\text { DURATION: Use of } 27 \text { sets of each product } \\
\text { WITHDRAWALS/DROPOUTS: None } \\
\text { ITT: Not applicable } \\
\text { GEOGRAPHICAL LOCATION: France } \\
\text { SETTING: Hospital outpatient clinic }\end{array}$} \\
\hline Participants & \multicolumn{2}{|l|}{$\begin{array}{l}\text { N }=27 \\
\text { DIAGNOSIS: Variable } \\
\text { ELIGIBLE: Not stated } \\
\text { ENROLLED: } 27 \\
\text { COMPLETED: } 27 \\
\text { AGE: Adults } \\
\text { GENDER: } 18 \text { males, } 9 \text { females }\end{array}$} \\
\hline Interventions & \multicolumn{2}{|c|}{ Comparison of 3 hydrophilic-coated (non-activated, water added by user) catheters } \\
\hline Outcomes & \multicolumn{2}{|c|}{ Self-reported infection, haematuria, user-reported satisfaction and ease of use } \\
\hline Notes & \multicolumn{2}{|c|}{ Nursing staff as well as participants completed questionnaires } \\
\hline
\end{tabular}

Risk of bias

\begin{tabular}{|c|c|c|}
\hline Bias & Authors' judgement & Support for judgement \\
\hline $\begin{array}{l}\text { Random sequence generation (selection } \\
\text { bias) }\end{array}$ & Low risk & $\begin{array}{l}\text { 'A random number was allocated to each } \\
\text { subject' }\end{array}$ \\
\hline Allocation concealment (selection bias) & Unclear risk & Not stated \\
\hline $\begin{array}{l}\text { Blinding of participants and personnel } \\
\text { (performance bias) } \\
\text { All outcomes }\end{array}$ & Low risk & Blinding of participants \\
\hline
\end{tabular}




\section{Mauroy 2001 (Continued)}

\begin{tabular}{l|l|l}
$\begin{array}{l}\text { Blinding of outcome assessment (detection } \\
\text { bias) } \\
\text { All outcomes }\end{array}$ & Unclear risk & $\begin{array}{l}\text { Participant and nurse-reported outcome - } \\
\text { risk of detection bias unclear }\end{array}$ \\
\hline $\begin{array}{l}\text { Incomplete outcome data (attrition bias) } \\
\text { All outcomes }\end{array}$ & Low risk & No missing outcome data. \\
\hline Source of Funding & Unclear risk & Not stated \\
\hline
\end{tabular}

Moore 1993

Methods

Methods

DESIGN: Randomised controlled cross-over trial with each arm 6 months BLINDING PROCEDURES: Not stated

SAMPLE CALCULATION: No

DURATION: 6 months

FOLLOW-UP: Monthly

WITHDRAWALS/DROPOUTS: Nil

ITT: Not applicable

GEOGRAPHICAL LOCATION: Canada

SETTING: Community

N $=30$
PIAGNOSIS: Neurogenic bladder due to spina bifida
ELIGIBLE: Unknown
ENROLLED: 30
COMPLETED: 30
AGE: Children
GENDER: 15 male, 15 female

Interventions

SINGLE VS MULTI USE:sterile single-use PVC or reused PVC (uncoated, non-lubricated catheters)

\begin{tabular}{ll} 
Outcomes & Bacteriuria $>10 \times 3$ CFU/mL obtained monthly; no difference between groups \\
\hline Notes & $\begin{array}{l}\text { Symptomatic UTI defined as + symptoms; catheters washed with liquid soap and water, } \\
\text { air dried and reused (does not indicate length of reuse); several participants took pro- } \\
\text { phylactic antibiotics }\end{array}$
\end{tabular}

\section{Risk of bias}

\begin{tabular}{l|ll}
\hline Bias & Authors' judgement & Support for judgement \\
\hline $\begin{array}{l}\text { Random sequence generation (selection } \\
\text { bias) }\end{array}$ & Unclear risk & Not stated \\
\hline Allocation concealment (selection bias) & Unclear risk & Not stated
\end{tabular}

Intermittent catheterisation for long-term bladder management (Review)

Copyright $\odot 2014$ The Cochrane Collaboration. Published by John Wiley \& Sons, Ltd. 
Moore 1993 (Continued)

\begin{tabular}{|c|c|c|}
\hline $\begin{array}{l}\text { Blinding of participants and personnel } \\
\text { (performance bias) } \\
\text { All outcomes }\end{array}$ & Low risk & $\begin{array}{l}\text { No blinding, but the review authors judge } \\
\text { that the outcome and outcome measure- } \\
\text { ment are not likely to be influenced by lack } \\
\text { of blinding }\end{array}$ \\
\hline $\begin{array}{l}\text { Blinding of outcome assessment (detection } \\
\text { bias) } \\
\text { All outcomes }\end{array}$ & Low risk & $\begin{array}{l}\text { "Both lab technologists were blind to the } \\
\text { arm of the crossover design" }\end{array}$ \\
\hline $\begin{array}{l}\text { Incomplete outcome data (attrition bias) } \\
\text { All outcomes }\end{array}$ & Low risk & No incomplete data \\
\hline Source of Funding & Unclear risk & $\begin{array}{l}\text { Spina Bifida Association of Northern \& } \\
\text { Southern Alberta and Canada, Baxter } \\
\text { Corporation,Canadian Hospital Suppliers, } \\
\text { Congdon's Aids to Daily Living, Glenrose } \\
\text { Rehabilitation Hospital, Lever Soap, Men- } \\
\text { tor Corporation, Northern Alberta Urol- } \\
\text { ogy Foundation, }\end{array}$ \\
\hline
\end{tabular}

Moore 2006

Methods

DESIGN: Randomised controlled trial

ALLOCATION: By third party using sealed opaque envelopes.

BLINDING PROCEDURES: Data entry blinded

SAMPLE CALCULATION: Yes

DURATION: Up to 12 months

FOLLOW-UP: Weekly urinalysis

WITHDRAWALS/DROPOUTS: None

ITT: Yes

GEOGRAPHICAL LOCATION: Canada

SETTING: Rehabilitation Hospital

\begin{tabular}{ll} 
Participants & N $=36$ \\
& DIAGNOSIS: Neurogenic bladder due to recent high spinal cord injury; neurogenic \\
bladder. & ELIGIBLE: 50 \\
ENROLLED: 36 \\
COMPLETED: 36 \\
AGE: Adults \\
GENDER: 28 male, 8 female \\
\hline
\end{tabular}

Interventions

Sterile technique vs clean technique Sterile single-use PVC catheter with sterile technique or sterile single-use PVC catheter with clean technique (clean gloves, clean container, non-sterile wipes for cleansing pre catheterisation) (uncoated, non-lubricated both arms)

Outcomes

Days to onset of symptomatic UTI

Intermittent catheterisation for long-term bladder management (Review)

Copyright (๑) 2014 The Cochrane Collaboration. Published by John Wiley \& Sons, Ltd. 
Moore 2006 (Continued)

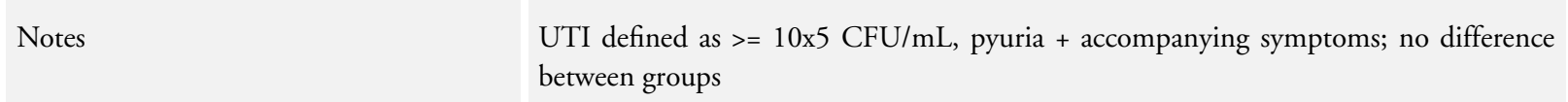

Risk of bias

\begin{tabular}{l|l|l}
\hline Bias & Authors' judgement & Support for judgement \\
\hline $\begin{array}{l}\text { Random sequence generation (selection } \\
\text { bias) }\end{array}$ & Low risk & “Computer generated random numbers" \\
\hline $\begin{array}{l}\text { Allocation concealment (selection bias) } \\
\text { Blinding of participants and personnel } \\
\text { (performance bias) } \\
\text { All outcomes }\end{array}$ & Lnclear risk & "Sealed brown envelopes" \\
\hline $\begin{array}{l}\text { Blinding of outcome assessment (detection } \\
\text { bias) } \\
\text { All outcomes }\end{array}$ & Low risk & "It was not possible to blind nursing staff” \\
\hline $\begin{array}{l}\text { Incomplete outcome data (attrition bias) } \\
\text { All outcomes }\end{array}$ & Low risk & $\begin{array}{l}\text { "laboratory was blinded to subject alloca- } \\
\text { tion" }\end{array}$ \\
\hline \begin{tabular}{l} 
Source of Funding \\
\hline
\end{tabular} & Low risk & No incomplete data \\
\hline
\end{tabular}

Moore 2013

\begin{tabular}{ll}
\hline Methods & DESIGN: Randomised controlled cross-over trial \\
& BLINDING PROCEDURES: Not possible to blind participants. \\
& SAMPLE CALCULATION: Yes \\
& DURATION: 48 weeks (24 weeks each arm) \\
& WITHDRAWALS/DROPOUTS: 24 \\
& ITT: Not applicable \\
& GEOGRAPHICAL LOCATION: 4 sites in Western Canada \\
& SETTING: Paediatric clinic \\
\hline Participants & N = 46 \\
& DIAGNOSIS: Spina bifida \\
& ELIGIBLE: Not stated \\
& ENROLLED: 70 \\
& COMPLETED: 46 \\
& AGE: Children \\
& GENDER: 21 male, 25 female \\
\hline Interventions & Hydrophilic-coated (not activated) single-use catheter with an uncoated, non-lubricated \\
(water added by user) multiple-use catheter
\end{tabular}


Moore 2013 (Continued)

\begin{tabular}{|c|c|c|}
\hline Outcomes & \multicolumn{2}{|c|}{$\begin{array}{l}\text { Symptomatic UTI, antimicrobial use, haematuria, days of missed activities, user-reported } \\
\text { satisfaction }\end{array}$} \\
\hline Notes & \multicolumn{2}{|c|}{$\begin{array}{l}\text { Hydrophilic catheters do not appear to reduce febrile UTI or antibiotic use in commu- } \\
\text { nity-dwelling children using CIC }\end{array}$} \\
\hline \multicolumn{3}{|l|}{ Risk of bias } \\
\hline Bias & Authors' judgement & Support for judgement \\
\hline $\begin{array}{l}\text { Random sequence generation (selection } \\
\text { bias) }\end{array}$ & Low risk & $\begin{array}{l}\text { 'Computer generated list into random } \\
\text { blocks of } 8 \text { ' }\end{array}$ \\
\hline Allocation concealment (selection bias) & Low risk & 'Sealed opaque envelopes' \\
\hline $\begin{array}{l}\text { Blinding of participants and personnel } \\
\text { (performance bias) } \\
\text { All outcomes }\end{array}$ & Low risk & $\begin{array}{l}\text { 'Not possible to blind subjects to product. } \\
\text { All data was entered by an impartial tech- } \\
\text { nician.' }\end{array}$ \\
\hline $\begin{array}{l}\text { Blinding of outcome assessment (detection } \\
\text { bias) } \\
\text { All outcomes }\end{array}$ & Low risk & $\begin{array}{l}\text { Risk of detection bias considered low as } \\
\text { cross-over trial. }\end{array}$ \\
\hline $\begin{array}{l}\text { Incomplete outcome data (attrition bias) } \\
\text { All outcomes }\end{array}$ & High risk & 24 participants dropped out \\
\hline Source of Funding & Unclear risk & $\begin{array}{l}\text { Glenrose Rehabilitation Hospital, Spina } \\
\text { Bifida Association of Northern Alberta, } \\
\text { Northern Alberta Urology Foundation } \\
\text { Canada, Coloplast A/S (products) }\end{array}$ \\
\hline
\end{tabular}

Pachler 1999

\begin{tabular}{ll} 
Methods & DESIGN: Randomised controlled cross-over trial \\
& BLINDING PROCEDURES: Not stated \\
& SAMPLE CALCULATION: No \\
& DURATION: 3 weeks each arm \\
& FOLLOW-UP: 3 weeks \\
& WITHDRAWALS/DROPOUTS: Not clear \\
& ITT: Not applicable \\
& GEOGRAPHICAL LOCATION: Denmark \\
& SETTING: Community \\
\hline Participants & N $=32$ \\
& DIAGNOSIS: Retention due to BPH \\
ELIGIBLE: Not stated \\
ENROLLED: 43 \\
COMPLETED: 32
\end{tabular}


Pachler 1999 (Continued)

AGE: Adults

GENDER: Male

Interventions

Hydrophilic-coated (not activated) (Lofric) single-use catheter with an uncoated, nonlubricated (water added by user) multiple-use catheter $\mathrm{x} 3$ weeks each

Outcomes

Urine for $\mathrm{C} \& S$ at baseline and each 3 week point; haematuria; responses to catheter use questionnaire

Notes

UTI defined as > $10 \times 4 \mathrm{CFU} / \mathrm{mL}$. No differences between groups in questionnaire response, bacteriuria or haematuria but short follow-up and small sample size. Unable to use data in Table of Comparisons because of cross-over design and no mid-point data

\section{Risk of bias}

\begin{tabular}{|c|c|c|}
\hline Bias & Authors' judgement & Support for judgement \\
\hline $\begin{array}{l}\text { Random sequence generation (selection } \\
\text { bias) }\end{array}$ & Unclear risk & Not stated \\
\hline Allocation concealment (selection bias) & Unclear risk & Not stated \\
\hline $\begin{array}{l}\text { Blinding of participants and personnel } \\
\text { (performance bias) } \\
\text { All outcomes }\end{array}$ & Low risk & $\begin{array}{l}\text { No blinding, but the review authors judge } \\
\text { that the outcome and outcome measure- } \\
\text { ment are not likely to be influenced by lack } \\
\text { of blinding }\end{array}$ \\
\hline $\begin{array}{l}\text { Blinding of outcome assessment (detection } \\
\text { bias) } \\
\text { All outcomes }\end{array}$ & Unclear risk & $\begin{array}{l}\text { Participant-reported outcome - risk of de- } \\
\text { tection bias unclear }\end{array}$ \\
\hline $\begin{array}{l}\text { Incomplete outcome data (attrition bias) } \\
\text { All outcomes }\end{array}$ & Unclear risk & $\begin{array}{l}\text { Unclear number of participants included } \\
\text { but not completed }\end{array}$ \\
\hline Source of Funding & Unclear risk & Kirudan A/S (products) \\
\hline
\end{tabular}

Pascoe 2001

Methods

DESIGN: Randomised controlled cross-over trial

BLINDING PROCEDURES: No

SAMPLE CALCULATION: No

DURATION: 1 week

WITHDRAWALS/DROPOUTS: 2

ITT: Not applicable

GEOGRAPHICAL LOCATION: UK

SETTING: Two test centres 
Pascoe 2001 (Continued)

\begin{tabular}{ll}
\hline Participants & N $=27$ \\
& DIAGNOSIS: Not stated. \\
& ELIGIBLE: Not stated \\
& ENROLLED: 27 \\
& COMPLETED: 25 \\
& AGE: Adults \\
& GENDER: Not stated \\
\hline Interventions & Hydrophilic-coated catheters, one activated and one not activated (water added by user) \\
\hline Outcomes & User satisfaction and ease of use \\
\hline Notes & \\
\hline
\end{tabular}

\section{Risk of bias}

\begin{tabular}{l|l|l}
\hline Bias & Authors' judgement & Support for judgement \\
\hline $\begin{array}{l}\text { Random sequence generation (selection } \\
\text { bias) }\end{array}$ & Unclear risk & Not stated \\
\hline $\begin{array}{l}\text { Allocation concealment (selection bias) } \\
\text { Blinding of participants and personnel } \\
\text { (performance bias) } \\
\text { All outcomes }\end{array}$ & Low risk & Not stated \\
\hline $\begin{array}{l}\text { Blinding of outcome assessment (detection } \\
\text { bias) } \\
\text { All outcomes }\end{array}$ & Low risk & $\begin{array}{l}\text { No blinding, but the review authors judge } \\
\text { that the outcome and outcome measure- } \\
\text { ment are not likely to be influenced by lack } \\
\text { of blinding }\end{array}$ \\
\hline $\begin{array}{l}\text { Incomplete outcome data (attrition bias) } \\
\text { All outcomes }\end{array}$ & Unclear risk & $\begin{array}{l}\text { Participant-reported outcome, but risk of } \\
\text { detection bias considered low as cross-over } \\
\text { trial }\end{array}$ \\
\hline \begin{tabular}{l} 
Source of Funding \\
\hline
\end{tabular} & Unclear risk & $\begin{array}{l}\text { Missing outcome data from 2 participants } \\
\text { - withdrawals described as catheter-related } \\
\text { reasons, but type of catheter not specified }\end{array}$ \\
\hline
\end{tabular}


Prieto-Fingerhut 1999

\begin{tabular}{|c|c|c|}
\hline Methods & \multicolumn{2}{|c|}{$\begin{array}{l}\text { DESIGN: Randomised controlled trial } \\
\text { BLINDING PROCEDURES: Not stated } \\
\text { SAMPLE CALCULATION: No } \\
\text { DURATION: Unclear } \\
\text { FOLLOW-UP: Unclear } \\
\text { WITHDRAWALS/DROPOUTS: Not stated } \\
\text { ITT: Not applicable } \\
\text { GEOGRAPHICAL LOCATION: USA } \\
\text { SETTING: Rehabiltiation }\end{array}$} \\
\hline Participants & \multicolumn{2}{|c|}{$\begin{array}{l}\mathrm{N}=29 \\
\text { DIAGNOSIS: Neurogenic bladder due to spinal cord injury } \\
\text { ELIGIBLE: Unknown } \\
\text { ENROLLED: } 29 \\
\text { COMPLETED: Not stated } \\
\text { AGE: Adults } \\
\text { GENDER: } 16 \text { male, } 13 \text { female }\end{array}$} \\
\hline Interventions & \multicolumn{2}{|c|}{$\begin{array}{l}\text { Single-use uncoated, pre-lubricated catheter with an integrated bag (sterile) versus mul- } \\
\text { tiple-use uncoated, non-lubricated catheter (CLEAN) }\end{array}$} \\
\hline Outcomes & \multicolumn{2}{|c|}{ UTI Urine for C\&S collected weekly - unclear on trial time frame or endpoint } \\
\hline Notes & \multicolumn{2}{|c|}{ UTI as defined by NIDRR (1992); higher \% of UTI in closed system (42\% vs 29\%) } \\
\hline \multicolumn{3}{|l|}{ Risk of bias } \\
\hline Bias & Authors' judgement & Support for judgement \\
\hline $\begin{array}{l}\text { Random sequence generation (selection } \\
\text { bias) }\end{array}$ & Unclear risk & Not stated \\
\hline Allocation concealment (selection bias) & Unclear risk & Not stated \\
\hline $\begin{array}{l}\text { Blinding of participants and personnel } \\
\text { (performance bias) } \\
\text { All outcomes }\end{array}$ & Low risk & $\begin{array}{l}\text { No blinding, but the review authors judge } \\
\text { that the outcome and outcome measure- } \\
\text { ment are not likely to be influenced by lack } \\
\text { of blinding }\end{array}$ \\
\hline $\begin{array}{l}\text { Blinding of outcome assessment (detection } \\
\text { bias) } \\
\text { All outcomes }\end{array}$ & Unclear risk & Not stated \\
\hline $\begin{array}{l}\text { Incomplete outcome data (attrition bias) } \\
\text { All outcomes }\end{array}$ & Low risk & $\begin{array}{l}\text { Not stated, but does not appear to be any } \\
\text { missing outcome data }\end{array}$ \\
\hline Source of Funding & Unclear risk & Medical Marketing Group Inc. US \\
\hline
\end{tabular}




\begin{tabular}{ll}
\hline Methods & DESIGN: Randomised controlled trial \\
& BLINDING PROCEDURES: Not stated \\
& SAMPLE CALCULATION: No \\
& DURATION: 4 days \\
& FOLLOW-UP: \\
& WITHDRAWALS/DROPOUTS: 10 \\
& ITT: Not stated \\
& GEOGRAPHICAL LOCATION: \\
& SETTING: Rehabilitation \\
\hline \multirow{3}{*}{ Participants } & N $=30$ \\
& DIAGNOSIS: Neurogenic bladder due to recent spinal cord injury or stroke \\
ELIGIBLE: Unknown \\
ENROLLED: 30 \\
COMPLETED: 20 \\
AGE: Adults \\
GENDER: Not stated \\
\hline
\end{tabular}
cated catheter, aseptic technique both arms

\begin{tabular}{ll}
\hline Outcomes & UTI $>10 \times 5$ CFU/mL + symptoms (fever, CV or SP tenderness) \\
\hline Notes & Data only collected for 4 days \\
\hline
\end{tabular}

\section{Risk of bias}

\begin{tabular}{|c|c|c|}
\hline Bias & Authors' judgement & Support for judgement \\
\hline $\begin{array}{l}\text { Random sequence generation (selection } \\
\text { bias) }\end{array}$ & Unclear risk & "randomly assigned" \\
\hline Allocation concealment (selection bias) & Low risk & $\begin{array}{l}\text { "blind selection of a marked piece of paper } \\
\text { from a box prepared for the particular ser- } \\
\text { vice" }\end{array}$ \\
\hline $\begin{array}{l}\text { Blinding of participants and personnel } \\
\text { (performance bias) } \\
\text { All outcomes }\end{array}$ & Low risk & $\begin{array}{l}\text { No blinding, but the review authors judge } \\
\text { that the outcome and outcome measure- } \\
\text { ment are not likely to be influenced by lack } \\
\text { of blinding }\end{array}$ \\
\hline $\begin{array}{l}\text { Blinding of outcome assessment (detection } \\
\text { bias) } \\
\text { All outcomes }\end{array}$ & Unclear risk & Not stated \\
\hline $\begin{array}{l}\text { Incomplete outcome data (attrition bias) } \\
\text { All outcomes }\end{array}$ & Low risk & $\begin{array}{l}\text { Outcome data is not reported for the miss- } \\
\text { ing participants but there were the same } \\
\text { number of participants with incomplete } \\
\text { data in each arm }\end{array}$ \\
\hline
\end{tabular}


Quigley 1993 (Continued)

\begin{tabular}{|c|c|c|}
\hline Source of Funding & Unclear risk & Bard Inc. \\
\hline
\end{tabular}

Sarica 2010

\begin{tabular}{|c|c|c|}
\hline Methods & \multicolumn{2}{|c|}{$\begin{array}{l}\text { DESIGN: Randomised controlled cross-over trial } \\
\text { BLINDING PROCEDURES: No } \\
\text { SAMPLE CALCULATION: No } \\
\text { DURATION: } 6 \text { weeks } \\
\text { WITHDRAWALS/DROPOUTS: } 11 \\
\text { ITT: Not applicable } \\
\text { GEOGRAPHICAL LOCATION: Turkey } \\
\text { SETTING: Hospital clinic }\end{array}$} \\
\hline Participants & \multicolumn{2}{|c|}{$\begin{array}{l}N=25 \\
\text { DIAGNOSIS: Spinal cord injury } \\
\text { ELIGIBLE: } 25 \\
\text { ENROLLED: } 21 \\
\text { COMPLETED: } 10 \text { (all three arms) } \\
\text { AGE: Adults } \\
\text { GENDER: Male }\end{array}$} \\
\hline Interventions & \multicolumn{2}{|c|}{$\begin{array}{l}\text { One uncoated (not lubricated), one pre-lubricated with integrated bag and one hy- } \\
\text { drophilic coated (water added by user) }\end{array}$} \\
\hline Outcomes & \multicolumn{2}{|c|}{ Urethral cytology, urine culture, user satisfaction } \\
\hline \multicolumn{3}{|l|}{ Notes } \\
\hline \multicolumn{3}{|l|}{ Risk of bias } \\
\hline Bias & Authors' judgement & Support for judgement \\
\hline $\begin{array}{l}\text { Random sequence generation (selection } \\
\text { bias) }\end{array}$ & Low risk & $\begin{array}{l}\text { "Sequence generated by table of random } \\
\text { numbers" }\end{array}$ \\
\hline Allocation concealment (selection bias) & Unclear risk & Not stated \\
\hline $\begin{array}{l}\text { Blinding of participants and personnel } \\
\text { (performance bias) } \\
\text { All outcomes }\end{array}$ & Low risk & $\begin{array}{l}\text { No blinding, but the review authors judge } \\
\text { that the outcome and outcome measure- } \\
\text { ment are not likely to be influenced by lack } \\
\text { of blinding }\end{array}$ \\
\hline $\begin{array}{l}\text { Blinding of outcome assessment (detection } \\
\text { bias) } \\
\text { All outcomes }\end{array}$ & Unclear risk & $\begin{array}{l}\text { "Urethral cytology samples were taken by a } \\
\text { blinded doctor" }\end{array}$ \\
\hline
\end{tabular}


Sarica 2010 (Continued)

\begin{tabular}{|c|c|c|}
\hline $\begin{array}{l}\text { Incomplete outcome data (attrition bias) } \\
\text { All outcomes }\end{array}$ & Unclear risk & $\begin{array}{l}\text { Missing data on one or more catheters from } \\
15 \text { participants - } 9 \text { participants gave non- } \\
\text { approval of catheter as the reason ( } 2 \text { gel- } \\
\text { lubricated catheter, } 5 \text { PVC catheter, } 2 \text { hy- } \\
\text { drophilic catheter) }\end{array}$ \\
\hline Source of Funding & Low risk & No funding \\
\hline
\end{tabular}

Schlager 2001

\begin{tabular}{|c|c|}
\hline Methods & $\begin{array}{l}\text { DESIGN: Randomised controlled cross-over trial. } \\
\text { BLINDING PROCEDURES: Not stated } \\
\text { SAMPLE CALCULATION: No } \\
\text { DURATION: Each arm was } 4 \text { months } \\
\text { FOLLOW-UP: Weekly home visit for urine for C\&S, catheter count, medication use } \\
\text { and symptoms or signs of UTI } \\
\text { WITHDRAWALS/DROPOUTS: None } \\
\text { ITT: Not applicable } \\
\text { GEOGRAPHICAL LOCATION: USA } \\
\text { SETTING: Community }\end{array}$ \\
\hline Participants & $\begin{array}{l}\mathrm{N}=10 \\
\text { DIAGNOSIS: Neurogenic bladder due to spina bifida } \\
\text { ELIGIBLE: } 12 \\
\text { ENROLLED: } 10 \\
\text { COMPLETED: } 10 \\
\text { AGE: Children } \\
\text { GENDER: } 4 \text { male, } 6 \text { female }\end{array}$ \\
\hline Interventions & Single vs multiuse Uncoated catheter, non-lubricated and clean technique both arms \\
\hline Outcomes & UTI weekly urine for C\&S x 4 months \\
\hline Notes & $\begin{array}{l}\text { UTI defined as }+ \text { or }>\text { than } 10 x 4 \mathrm{CFU} / \mathrm{mL} \text { plus symptoms (fever, pain, change in } \\
\text { continence, change in colour or odour of urine); } \\
\text { No differences between groups ( } 2 \mathrm{Sx} \text { UTI each). SS too small to draw any conclusions } \\
\text { about effectiveness. } \\
\text { Catheter cleaning: PVC rinsed with tap water, air dried. At end of day catheters were } \\
\text { boiled x } 3 \text { minutes, air dried and stored in clean bag }\end{array}$ \\
\hline
\end{tabular}

Risk of bias

\begin{tabular}{|c|c|c|}
\hline Bias & Authors' judgement & Support for judgement \\
\hline $\begin{array}{l}\text { Random sequence generation (selection } \\
\text { bias) }\end{array}$ & Unclear risk & "randomised" \\
\hline
\end{tabular}

Intermittent catheterisation for long-term bladder management (Review) 


\section{Schlager 2001 (Continued)}

\begin{tabular}{|c|c|c|}
\hline Allocation concealment (selection bias) & Unclear risk & Not stated \\
\hline $\begin{array}{l}\text { Blinding of participants and personnel } \\
\text { (performance bias) } \\
\text { All outcomes }\end{array}$ & Low risk & $\begin{array}{l}\text { No blinding, but the review authors judge } \\
\text { that the outcome and outcome measure- } \\
\text { ment are not likely to be influenced by lack } \\
\text { of blinding }\end{array}$ \\
\hline $\begin{array}{l}\text { Blinding of outcome assessment (detection } \\
\text { bias) } \\
\text { All outcomes }\end{array}$ & Unclear risk & $\begin{array}{l}\text { Not stated whether laboratory technician } \\
\text { was blinded to catheter }\end{array}$ \\
\hline $\begin{array}{l}\text { Incomplete outcome data (attrition bias) } \\
\text { All outcomes }\end{array}$ & Low risk & Minimal missing data \\
\hline Source of Funding & Unclear risk & Mentor Corporation US \\
\hline
\end{tabular}

\section{Sutherland 1996}

\begin{tabular}{|c|c|}
\hline Methods & $\begin{array}{l}\text { DESIGN: Randomised controlled trial } \\
\text { BLINDING PROCEDURES: Not stated } \\
\text { SAMPLE CALCULATION: No } \\
\text { DURATION: } 8 \text { weeks } \\
\text { FOLLOW-UP: Weekly urine C\&S and microscopy x } 8 \text { weeks. } \\
\text { WITHDRAWALS/DROPOUTS: } 3 \\
\text { ITT: Not stated } \\
\text { GEOGRAPHICAL LOCATION: USA } \\
\text { SETTING: community }\end{array}$ \\
\hline Participants & $\begin{array}{l}\text { N = } 33 \\
\text { DIAGNOSIS: Neurogenic bladder due to spinal cord injury, Hinman syndrome, spinal } \\
\text { dysraphism; } \\
\text { ELIGIBLE: Not stated } \\
\text { ENROLLED: } 33 \\
\text { COMPLETED: } 30 \\
\text { AGE: Children } \\
\text { GENDER: Male }\end{array}$ \\
\hline Interventions & $\begin{array}{l}\text { Hydrophilic-coated (not activated) (Lofric) single-use catheter with an uncoated, non- } \\
\text { lubricated (water added by user) multiple-use catheter. } \\
\text { Method of cleaning catheter and length of reuse not described }\end{array}$ \\
\hline Outcomes & $\begin{array}{l}\text { UTI } \\
\text { Haematuria > } 3 \text { RBC per HPF; } \\
\text { VAS for satisfaction; }\end{array}$ \\
\hline Notes & $\begin{array}{l}\text { UTI defined as } 10 \times 5 \mathrm{CFU} / \mathrm{mL}+\mathrm{S} \text { (not defined); participants with positive cultures } \\
\text { were treated and re-entered into the trial; no diff in bacteriuria b/w groups; haematuria } \\
\text { lower in Lofric group but } \mathrm{SS} \text { too small to draw conclusions and groups included gastric }\end{array}$ \\
\hline
\end{tabular}


Sutherland 1996 (Continued)

augmentation as well

\section{Risk of bias}

\begin{tabular}{l|l|l}
\hline Bias & Authors' judgement & Support for judgement \\
\hline $\begin{array}{l}\text { Random sequence generation (selection } \\
\text { bias) }\end{array}$ & High risk & "assigned” \\
\hline $\begin{array}{l}\text { Allocation concealment (selection bias) } \\
\text { Blinding of participants and personnel } \\
\text { (performance bias) } \\
\begin{array}{l}\text { All outcomes } \\
\text { Low risk }\end{array}\end{array}$ & Unclear risk & Not stated \\
\hline
\end{tabular}

Blinding of outcome assessment (detection Unclear risk bias)

Not stated whether laboratory technician was blinded to catheter

All outcomes

Incomplete outcome data (attrition bias) Low risk All outcomes

3 participants did not complete the trial, 2 in one arm and 1 in the other. Reasons for missing data unlikely to be related to outcome

\begin{tabular}{|c|c|}
\hline Source of Funding & Unclear risk \\
\hline
\end{tabular}

Taweesangsuksalul 2005

Methods

DESIGN: Randomised controlled cross-over trial

BLINDING PROCEDURES: Double blind

SAMPLE CALCULATIONS: NO

DURATION: 1 procedure

FOLLOW-UP: None

WITHDRAWLS/DROPOUTS: None

ITT: Not applicable

GEOGRAPHICAL LOCATION: Thailand

SETTING: Not stated

Narticipants
DIAGNOSIS: Neurogenic bladder disfunction
ELIGIBLE: Not stated
ENROLLED: 10
COMPLETED: 10
AGE: Adults
GENDER: 4 male, 6 female

Interventions

Aloe vera versus aqueous gel as lubricant

Intermittent catheterisation for long-term bladder management (Review)

Copyright @ 2014 The Cochrane Collaboration. Published by John Wiley \& Sons, Ltd. 
Taweesangsuksalul 2005 (Continued)

\begin{tabular}{|c|c|c|}
\hline Outcomes & \multicolumn{2}{|l|}{$\begin{array}{l}\text { Catheterisation time } \\
\text { Adverse effect } \\
\text { Satisfaction (nurse and participant) }\end{array}$} \\
\hline Notes & \multicolumn{2}{|c|}{ Article written in Thai, abstract available in English. } \\
\hline \multicolumn{3}{|l|}{ Risk of bias } \\
\hline Bias & Authors' judgement & Support for judgement \\
\hline $\begin{array}{l}\text { Random sequence generation (selection } \\
\text { bias) }\end{array}$ & Unclear risk & Not stated in abstract \\
\hline Allocation concealment (selection bias) & Unclear risk & Not stated in abstract \\
\hline $\begin{array}{l}\text { Blinding of participants and personnel } \\
\text { (performance bias) } \\
\text { All outcomes }\end{array}$ & Low risk & Double blind \\
\hline $\begin{array}{l}\text { Blinding of outcome assessment (detection } \\
\text { bias) } \\
\text { All outcomes }\end{array}$ & Low risk & Double blind \\
\hline $\begin{array}{l}\text { Incomplete outcome data (attrition bias) } \\
\text { All outcomes }\end{array}$ & Low risk & No dropouts reported \\
\hline Source of Funding & Unclear risk & Not stated \\
\hline
\end{tabular}

\section{Vapnek 2003}

\begin{tabular}{ll} 
Methods & DESIGN: Randomised controlled trial \\
& BLINDING PROCEDURES: Not stated \\
& SAMPLE CALCULATION: No \\
& DURATION: 12 months \\
& FOLLOW-UP: Urine C\&S every 3 months \\
& WITHDRAWALS/DROPOUTS: 13 \\
& ITT: Not stated \\
& GEOGRAPHICAL LOCATION: 3 sites in USA \\
& SETTING: Community \\
\hline \multirow{3}{*}{ Participants } & N $=62$ \\
& DIAGNOSIS: Neurogenic bladder (cause not stated) \\
ELIGIBLE: Not stated \\
ENROLLED: 62 \\
COMPLETED: 49 \\
AGE: Adults \\
GENDER: Male
\end{tabular}


Vapnek 2003 (Continued)

\begin{tabular}{|c|c|c|}
\hline Interventions & \multicolumn{2}{|c|}{$\begin{array}{l}\text { Hydrophilic-coated (not activated) (Lofric) single-use catheter with an uncoated, non- } \\
\text { lubricated (water added by user) multiple-use catheter. Reuse time } 24 \text { hours }\end{array}$} \\
\hline Outcomes & \multicolumn{2}{|c|}{ UTI; pyuria; haematuria. } \\
\hline Notes & \multicolumn{2}{|c|}{$\begin{array}{l}\text { UTI defined as } 10 \times 5 \mathrm{CFU} / \mathrm{mL}+\text { at least one clinical symptom (fever, chills, malodor- } \\
\text { ous urine, increased spasticity, malaise). Catheter cleaning not described; used } 1 \text { reused } \\
\text { catheter per day. } \\
\text { No statistically significant group differences were noted; unclear how long participants } \\
\text { were using IC before entering trial; pre trial UTI based on participant recall }\end{array}$} \\
\hline \multicolumn{3}{|l|}{ Risk of bias } \\
\hline Bias & Authors' judgement & Support for judgement \\
\hline $\begin{array}{l}\text { Random sequence generation (selection } \\
\text { bias) }\end{array}$ & Unclear risk & “randomised fashion” \\
\hline Allocation concealment (selection bias) & Unclear risk & Not stated \\
\hline $\begin{array}{l}\text { Blinding of participants and personnel } \\
\text { (performance bias) } \\
\text { All outcomes }\end{array}$ & Low risk & $\begin{array}{l}\text { No blinding, but the review authors judge } \\
\text { that the outcome and outcome measure- } \\
\text { ment are not likely to be influenced by lack } \\
\text { of blinding }\end{array}$ \\
\hline $\begin{array}{l}\text { Blinding of outcome assessment (detection } \\
\text { bias) } \\
\text { All outcomes }\end{array}$ & Unclear risk & $\begin{array}{l}\text { Not stated whether laboratory technician } \\
\text { was blinded to catheter }\end{array}$ \\
\hline $\begin{array}{l}\text { Incomplete outcome data (attrition bias) } \\
\text { All outcomes }\end{array}$ & Unclear risk & $\begin{array}{l}\text { Withdrawal rate greater in the experimen- } \\
\text { tal arm ( } 8 \text { vs 5). "Two patients per group } \\
\text { related to the type of catheter used" }\end{array}$ \\
\hline Source of Funding & Unclear risk & Astro Tech $\mathrm{AB}$ \\
\hline
\end{tabular}

Witjes 2009

Methods

DESIGN: Randomised controlled trial

BLINDING PROCEDURES: Double blind

SAMPLE CALCULATION: Yes

DURATION: 4 weeks

WITHDRAWALS/DROPOUTS: Unclear

ITT: Yes and also per protocol analysis

GEOGRAPHICAL LOCATION: 6 European countries (13 centres)

SETTING: Community 
Witjes 2009 (Continued)

\begin{tabular}{ll}
\hline Participants & N $=195$ \\
& DIAGNOSIS: Mixed \\
ELIGIBLE: Not stated \\
ENROLLED: 195 \\
COMPLETED: Unclear \\
AGE: Adults \\
GENDER: 151 male; 44 female \\
\hline
\end{tabular}

Interventions

Hydrophilic-coated catheter, not activated, sterile water provided versus hydrophiliccoated catheter, not activated, water added by user (aseptic technique both arms)

\begin{tabular}{l|l}
\hline Outcomes & Participant perception of handling \\
\hline Notes & Participant perception of handling was rated similarly in both groups
\end{tabular}

\section{Risk of bias}

\begin{tabular}{|c|c|c|}
\hline Bias & Authors' judgement & Support for judgement \\
\hline $\begin{array}{l}\text { Random sequence generation (selection } \\
\text { bias) }\end{array}$ & Unclear risk & Not stated \\
\hline Allocation concealment (selection bias) & Unclear risk & Not stated \\
\hline $\begin{array}{l}\text { Blinding of participants and personnel } \\
\text { (performance bias) } \\
\text { All outcomes }\end{array}$ & Low risk & $\begin{array}{l}\text { "Since most polymeric materials are visu- } \\
\text { ally similar, comparable materials could be } \\
\text { produced and packaged in identical form" } \\
\text { This was set up as a double-blind trial. }\end{array}$ \\
\hline $\begin{array}{l}\text { Blinding of outcome assessment (detection } \\
\text { bias) } \\
\text { All outcomes }\end{array}$ & Low risk & This was set up as a double-blind trial. \\
\hline $\begin{array}{l}\text { Incomplete outcome data (attrition bias) } \\
\text { All outcomes }\end{array}$ & Low risk & $\begin{array}{l}\text { Similar incomplete outcome data in con- } \\
\text { trol }(n=6) \text { and intervention }(n=10) \text { groups }\end{array}$ \\
\hline Source of Funding & Unclear risk & Not stated \\
\hline
\end{tabular}

BPH: benign prostatic hyperplasia

$\mathrm{CFU} / \mathrm{mL}$ : colony-forming unit per millilitre

CIC: Clean Intermittent Catheterization

C\&S: culture and sensitivity

IC: intermittent catheterisation

ICU: intensive care unit

ISC-Q: Intermittent Self-Catheterisation Questionnaire

ITT: intention-to-treat

NIDRR: National Institute on Disability and Rehabilitation Research 
RBC per HPF: red blood cell per

RCT: randomised controlled trial

SS:

UI: urinary infection

UTI: urinary tract infection

VAS: visual analogue scale

Characteristics of excluded studies [ordered by study ID]

\begin{tabular}{ll}
\hline Study & Reason for exclusion \\
\hline Bagi 2011 & Healthy volunteers used. \\
\hline Bennett 1997 & $\begin{array}{l}\text { Comparison of non-hydrophilic gel lubricated catheter with or without an introducer tip to reduce UTI. Study } \\
\text { design not clear }\end{array}$ \\
\hline
\end{tabular}

Charbonneau 1993 Retrospective chart review of incidence of UTI in participants using standard practice IC in rehabilitation from 1985-1988 then evaluation of UTI in 18 participants of a closed catheter/bag system. Not a RCT

Clarke 2005 RCT comparing effect of prophylactic antimicrobial treatment versus discontinuation of antimicrobial treatment on UTI in IC users (children with neuropathic bladder)

Diokno 1995 Evaluation of participant satisfaction with a pre-lubricated hydrophilic catheter for IC. Not a RCT

Edokpolo $2012 \quad$ Retrospective trial of UTI in long term IC users with spinal cord injury. Not a RCT

Feng 2009 Article in Chinese; abstract in English. RCT comparing effect of moxibustion and IC versus IC alone on bladder function in participants with neurogenic bladder dysfunction

Grigoleit 2006 Article in German; appears to be a review of catheterisation methods (based on short English abstract)

Hosseini 2008 RCT comparing effect of clean IC with triamicinolone ointment versus water-based lubricant on stricture formation in participants following internal urethrotomy due to obstruction/stricture

Hudson 2005 Laboratory trial evaluating the likelihood of catheter contamination based on catheter design; did not compare incidence of UTI. Not a RCT

Litherland 2007 RCT comparing effect of two hydrophilic-coated catheters on participant-perceived discomfort. One procedure only. Non-IC users undergoing gynaecology testing

Martins 2009 Cross-over trial (non-randomised) comparing hydrophilic-coated catheter versus an uncoated catheter in children with a urostomy

Nalinthip 1996 Article in Thai; abstract translated. Comparison of UTI rate when IC performed by participant or nurse

Sallami 2011 RCT comparing effect of clean IC using a hydrophilic catheter versus a standard PVC nelaton catheter on participant satisfaction, complications and recurrence of urethral stricture following endoscopic urethrotomy 
(Continued)

Sherbondy 2002 Survey of individuals using IC and reusing the catheter. Not a RCT

Sims 1993 Chart review of two different cleaning methods and comparison of UTI (wash with soap and water then soak in povidone iodine or allow to air dry). Not a RCT

Stensballe 2005

Laboratory evaluation (RCT) of friction force of 2 hydrophilic catheters and one non-hydrophilic catheter. RCT. Healthy volunteers used

Terpenning 1989

Observational trial of the incidence and time to onset of UTI in elderly in a Veterans Administration Centre (USA). Not a RCT

IC: intermittent catheterisation

RCT: randomised controlled trial

UTI: urinary tract infection 
DATA ANDANALYSES

Comparison 1. Aseptic technique versus clean/other aseptic technique

\begin{tabular}{|c|c|c|c|c|}
\hline Outcome or subgroup title & $\begin{array}{l}\text { No. of } \\
\text { studies }\end{array}$ & $\begin{array}{c}\text { No. of } \\
\text { participants }\end{array}$ & Statistical & Effect size \\
\hline $\begin{array}{l}1 \text { Number with asymptomatic } \\
\text { bacteriuria }\end{array}$ & 2 & & Risk Ratio (M-H, Fixed, 95\% CI) & Totals not selected \\
\hline $\begin{array}{l}\text { 1.1 Aseptic versus clean } \\
\text { technique (uncoated, } \\
\text { non-lubricated both arms) }\end{array}$ & 1 & & Risk Ratio (M-H, Fixed, 95\% CI) & $0.0[0.0,0.0]$ \\
\hline $\begin{array}{l}1.2 \text { Aseptic (closed) technique } \\
\text { (uncoated pre-lubricated } \\
\text { catheter) versus aseptic (open) } \\
\text { technique (uncoated catheter, } \\
\text { non-lubricated) }\end{array}$ & 1 & & Risk Ratio (M-H, Fixed, 95\% CI) & $0.0[0.0,0.0]$ \\
\hline 2 Number with symptomatic UTI & 5 & & Risk Ratio (M-H, Fixed, 95\% CI) & Subtotals only \\
\hline $\begin{array}{l}2.1 \text { Aseptic versus clean/other } \\
\text { aseptic technique (uncoated } \\
\text { catheter, non-lubricated both } \\
\text { arms) }\end{array}$ & 4 & 191 & Risk Ratio (M-H, Fixed, 95\% CI) & $1.06[0.77,1.45]$ \\
\hline $\begin{array}{l}2.2 \text { Aseptic (closed) technique } \\
\text { (uncoated pre-lubricated } \\
\text { catheter) versus aseptic (open) } \\
\text { technique (uncoated catheter, } \\
\text { non-lubricated) }\end{array}$ & 1 & & Risk Ratio (M-H, Fixed, 95\% CI) & $0.82[0.06,11.33]$ \\
\hline $\begin{array}{l}3 \text { Weeks to onset of symptomatic } \\
\text { UTI }\end{array}$ & 3 & & Mean Difference (IV, Fixed, 95\% CI) & Subtotals only \\
\hline $\begin{array}{l}3.1 \text { Aseptic technique versus } \\
\text { clean technique (uncoated } \\
\text { catheter, non-lubricated both } \\
\text { arms) }\end{array}$ & & 162 & Mean Difference (IV, Fixed, 95\% CI) & $0.15[-0.35,0.64]$ \\
\hline
\end{tabular}

Comparison 2. Single-ise (sterile) catheter versus multiple-use (clean) catheter

\begin{tabular}{lcccc} 
Outcome or subgroup title & $\begin{array}{c}\text { No. of } \\
\text { studies }\end{array}$ & $\begin{array}{c}\text { No. of } \\
\text { participants }\end{array}$ & Statistical method & Effect size \\
\hline $\begin{array}{l}1 \text { Number with asymptomatic } \\
\text { bacteriuria }\end{array}$ & 4 & & Risk Ratio (M-H, Random, 95\% CI) & Subtotals only \\
$\begin{array}{l}1.1 \text { Uncoated catheter, } \\
\text { non-lubricated and clean } \\
\text { technique both arms }\end{array}$ & 3 & 108 & Risk Ratio (M-H, Random, 95\% CI) & $1.08[0.86,1.36]$ \\
\hline $\begin{array}{l}\text { Intermittent catheterisation for long-term bladder management (Review) } \\
\text { Copyright } \odot \mathbf{2 0 1 4} \text { The Cochrane Collaboration. Published by John Wiley \& Sons, Ltd. }\end{array}$ & $\mathbf{6 0}$
\end{tabular}


1.2 Hydrophilic-coated catheter, not activated (single-use arm, clean technique) versus uncoated catheter, non-lubricated (multi use arm, clean technique)

2 Number with symptomatic UTI 2.1 Hydrophilic-coated catheter, not activated (single-use arm, clean technique) versus uncoated catheter, non-lubricated (multi use arm, clean technique)

2.2 Uncoated catheter, non-lubricated and clean technique both arms 2.3 Hydrophilic-coated catheter, activated versus uncoated, non-lubricated (clean technique in both arms) 2.4 Uncoated catheter, non-lubricated both arms, aseptic technique in single-use arm, clean technique in multiple-use arm

2.5 Uncoated catheter, pre-lubricated, closed system with integrated bag with aseptic technique in single-use arm versus uncoated catheter, non-lubricated, clean technique in multiple-use arm

3 Weeks to onset of symptomatic UTI

3.1 Uncoated catheter, non-lubricated both arms, aseptic technique in single-use arm, clean technique in multiple-use arm

4 Number with microscopic haematuria

4.1 Hydrophilic-coated catheter, not activated, water added by user (single-use arm, clean technique) versus uncoated catheter, non-lubricated (multi use arm, clean technique)

5 Number with urethral trauma/bleeding/macroscopic haematuria
Risk Ratio (M-H, Fixed, 95\% CI)

$1.21[0.65,2.23]$

Subtotals only 

uncoated, non-lubricated (clean technique in both arms) added by user (single-use arm, clean technique) versus uncoated catheter, non-lubricated (multi use arm, clean technique)

8 Number reporting ease of handling

8.1 Hydrophilic-coated added by user (single-use arm, clean technique) versus uncoated catheter, non-lubricated (multi use arm, clean technique)

8.2 Hydrophilic-coated catheter, activated versus uncoated, non-lubricated (clean technique in both arms)

9 Mean ease of handling 9.1 Hydrophilic-coated catheter, not activated, water added by user (single-use arm, clean technique) versus uncoated catheter, non-lubricated (multi use arm, clean technique)

10 Number reporting ease of insertion

10.1 Hydrophilic-coated catheter, not activated, water added by user (single-use arm, clean technique) versus uncoated catheter, non-lubricated (multi use arm, clean technique)

Risk Ratio (M-H, Fixed, 95\% CI)

$0.0[0.0,0.0]$

Mean Difference (IV, Fixed, 95\% CI)

Totals not selected Mean Difference (IV, Fixed, 95\% CI)

$0.0[0.0,0.0]$
Totals not selected

$0.0[0.0,0.0]$

Intermittent catheterisation for long-term bladder management (Review)

Mean Difference (IV, Fixed, 95\% CI)

Totals not selected 
11.1 Hydrophilic-coated catheter, not activated, water added by user (single-use arm, clean technique) versus uncoated catheter, non-lubricated (multi use arm, clean technique)

12 Number reporting comfort 12.1 Hydrophilic-coated catheter, activated versus uncoated, non-lubricated (clean technique in both arms)

13 Number reporting convenience of product

13.1 Hydrophilic-coated catheter, activated versus uncoated, non-lubricated (clean technique in both arms)

14 Mean convenience of product 14.1 Hydrophilic-coated catheter, not activated, water added by user (single-use arm, clean technique) versus uncoated catheter, non-lubricated (multi use arm, clean technique)
Risk Ratio (M-H, Fixed, 95\% CI) Risk Ratio (M-H, Fixed, 95\% CI)

Risk Ratio (M-H, Fixed, 95\% CI)

Risk Ratio (M-H, Fixed, 95\% CI)

1

Mean Difference (IV, Fixed, 95\% CI)

Mean Difference (IV, Fixed, 95\% CI)
Totals not selected $0.0[0.0,0.0]$

Totals not selected

$0.0[0.0,0.0]$

Totals not selected $0.0[0.0,0.0]$

Comparison 3. Hydrophilic-coated or other pre-lubricated catheter versus other catheter (pre-lubricated, coated or uncoated)

\begin{tabular}{|c|c|c|c|c|}
\hline Outcome or subgroup title & $\begin{array}{l}\text { No. of } \\
\text { studies }\end{array}$ & $\begin{array}{c}\text { No. of } \\
\text { participants }\end{array}$ & Statistical method & Effect size \\
\hline $\begin{array}{l}1 \text { Number with asymptomatic } \\
\text { bacteriuria }\end{array}$ & 1 & & Risk Ratio (M-H, Fixed, 95\% CI) & Totals not selected \\
\hline $\begin{array}{l}1.1 \text { Hydrophilic-coated } \\
\text { catheter (not activated, water } \\
\text { added by user) single use versus } \\
\text { uncoated, non-lubricated, } \\
\text { water-soluble gel added by user, } \\
\text { multiple use }\end{array}$ & 1 & & Risk Ratio (M-H, Fixed, 95\% CI) & $0.0[0.0,0.0]$ \\
\hline 2 Number with symptomatic UTI & 5 & & Risk Ratio (M-H, Fixed, 95\% CI) & Totals not selected \\
\hline $\begin{array}{l}2.1 \text { Hydrophilic-coated } \\
\text { catheter, not activated, water } \\
\text { added by user versus uncoated } \\
\text { catheter, non-lubricated (single } \\
\text { use both arms) }\end{array}$ & 1 & & Risk Ratio (M-H, Fixed, 95\% CI) & $0.0[0.0,0.0]$ \\
\hline
\end{tabular}

Intermittent catheterisation for long-term bladder management (Review)

Copyright $\odot 2014$ The Cochrane Collaboration. Published by John Wiley \& Sons, Ltd. 
non-lubricated (single use both arms)

3 Number of UTIs per month of use

3.1 Hydrophilic-coated catheter, activated versus uncoated catheter,

non-lubricated (single use both arms)

4 Number with urethral trauma/bleeding/macroscopic haematuria

4.1 Hydrophilic-coated catheter, activated versus uncoated catheter, non-lubricated (single use both arms)

4.2 Hydrophilic-coated activated catheter with integrated bag versus uncoated, pre-lubricated catheter with integrated bag (aseptic technique, single use both arms)

4.3 Hydrophilic-coated catheter (not activated, water added by user) single use versus uncoated, non-lubricated, water-soluble gel added by user, multiple use

5 Number with microscopic haematuria 
$$
\begin{aligned}
& \text { Risk Ratio (M-H, Fixed, 95\% CI) } \\
& \text { Risk Ratio (M-H, Fixed, 95\% CI) }
\end{aligned}
$$

catheter (activated)

versus uncoated catheter,

non-lubricated (single use both arms)

8 Number reporting overall satisfaction

8.1 Hydrophilic-coated

Risk Ratio (M-H, Fixed, 95\% CI)

Totals not selected catheter (activated) versus uncoated catheter, non-lubricated (single use both arms)

8.2 Hydrophilic-coated catheter, not activated, sterile water provided in package for activation versus hydrophilic-coated catheter, not activated, water added by user (aseptic technique both arms)

8.3 Hydrophilic-coated catheter, activated versus uncoated, non-lubricated (clean technique in both arms)

9 Mean Overall satisfaction 9.1 Hydrophilic-coated catheter, activated versus uncoated catheter, non-lubricated (single use both arms)

1

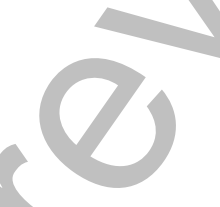

1
Totals not selected $0.0[0.0,0.0]$

Risk Ratio (M-H, Fixed, 95\% CI)

$0.0[0.0,0.0]$

Risk Ratio (M-H, Fixed, 95\% CI)

$0.0[0.0,0.0]$

310

Mean Difference (IV, Fixed, 95\% CI)

$-0.74[-1.07,-0.40]$

Mean Difference (IV, Fixed, 95\% CI)

Intermittent catheterisation for long-term bladder management (Review) 
catheter, not activated, water

added by user (single-use

arm, clean technique)

versus uncoated catheter,

non-lubricated (multi use arm,

clean technique)

9.3 Hydrophilic-coated

1 activated catheter with integrated bag versus pre-lubricated catheter with integrated bag (aseptic technique, single use both arms)

10 Number reporting preference 10.1 Hydrophilic-coated catheter, not activated, water

added by user (single-use arm, clean technique) versus uncoated catheter, non-lubricated (multi use arm, clean technique)

10.2 Hydrophilic-coated

versus uncoated catheter,

non-lubricated (single use both arms)

10.3 Hydrophilic-coated

Risk Ratio (M-H, Fixed, 95\% CI)

$0.53[0.30,0.93]$ activated catheter with integrated bag versus uncoated, pre-lubricated catheter with integrated bag (aseptic technique, single use both arms)

11 Number reporting convenience of product

11.1 Hydrophilic-coated catheter, activated versus uncoated, non-lubricated (clean technique in both arms)

12 Mean convenience of product 12.1 Hydrophilic-coated catheter, not activated, water added by user (single-use arm, clean technique) versus uncoated catheter, non-lubricated (multi use arm, clean technique)

13 Number reporting ease of

Risk Ratio (M-H, Fixed, 95\% CI)

Risk Ratio (M-H, Fixed, 95\% CI)

Mean Difference (IV, Fixed, 95\% CI)

Mean Difference (IV, Fixed, 95\% CI)
Totals not selected $0.0[0.0,0.0]$ handling

Totals not selected 
13.1 Hydrophilic-coated catheter, activated versus uncoated, non-lubricated (clean technique in both arms) 13.2 Hydrophilic-coated catheter, not activated, water added by user (single-use arm, clean technique) versus uncoated catheter, non-lubricated (multi use arm, clean technique)

14 Mean ease of handling 14.1 Hydrophilic-coated catheter, not activated, water added by user (single-use arm, clean technique) versus uncoated catheter, non-lubricated (multi use arm, clean technique)

15 Number reporting ease of insertion

15.1 Hydrophilic-coated catheter, not activated, water added by user (single-use arm, clean technique) versus uncoated catheter, non-lubricated (multi use arm, clean technique)

15.2 Hydrophilic-coated catheter, not activated, sterile water provided versus hydrophilic-coated catheter, not activated, water added by user (aseptic technique both arms)

15.3 Hydrophilic-coated activated catheter with integrated bag versus uncoated, pre-lubricated catheter with integrated bag (aseptic technique, single use both arms)

16 Mean ease of insertion 16.1 Hydrophilic-coated catheter, activated versus uncoated catheter, non-lubricated (single use both arms)
Totals not selected Mean Difference (IV, Fixed, 95\% CI)

$0.0[0.0,0.0]$

Risk Ratio (M-H, Random, 95\% CI)

$0.0[0.0,0.0]$

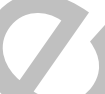

Risk Ratio (M-H, Random, 95\% CI)

$0.0[0.0,0.0]$ 
16.2 Hydrophilic-coated catheter, not activated, water added by user (single-use arm, clean technique) versus uncoated catheter, non-lubricated (multi use arm, clean technique)

17 Number reporting comfort 17.1 Hydrophilic-coated catheter, activated versus uncoated, non-lubricated (clean technique in both arms)

18 Mean ease of removal 18.1 Hydrophilic-coated catheter, activated versus uncoated catheter, non-lubricated (single use both arms)

\section{1}

Mean Difference (IV, Fixed, 95\% CI)

$0.0[0.0,0.0]$

Risk Ratio (M-H, Fixed, 95\% CI) Risk Ratio (M-H, Fixed, 95\% CI)

Totals not selected $0.0[0.0,0.0]$

Mean Difference (IV, Fixed, 95\% CI)

Totals not selected Mean Difference (IV, Fixed, 95\% CI)

\section{Comparison 4. Standard catheter versus shorter catheter length}

\begin{tabular}{|c|c|c|c|c|}
\hline Outcome or subgroup title & $\begin{array}{l}\text { No. of } \\
\text { studies }\end{array}$ & o. & Statistical method & Effect size \\
\hline $\begin{array}{l}1 \text { Number reporting ease of } \\
\text { handling }\end{array}$ & 3 & & Risk Ratio (M-H, Fixed, 95\% CI) & Subtotals only \\
\hline $\begin{array}{l}\text { 1.1 Hydrophilic-coated versus } \\
\text { hydrophilic-coated }\end{array}$ & 2 & 132 & Risk Ratio (M-H, Fixed, 95\% CI) & $0.42[0.15,1.12]$ \\
\hline $\begin{array}{l}1.2 \text { Uncoated catheter versus } \\
\text { uncoated catheter }\end{array}$ & 1 & 162 & Risk Ratio (M-H, Fixed, 95\% CI) & $2.38[1.10,5.11]$ \\
\hline $\begin{array}{l}2 \text { Number reporting ease of } \\
\text { insertion }\end{array}$ & 3 & & Risk Ratio (M-H, Fixed, 95\% CI) & Subtotals only \\
\hline $\begin{array}{l}2.1 \text { Hydrophilic-coated } \\
\text { hydrophilic-coated }\end{array}$ & 2 & 132 & Risk Ratio (M-H, Fixed, 95\% CI) & $1.17[1.02,1.35]$ \\
\hline $\begin{array}{l}2.2 \text { Uncoated catheter versus } \\
\text { uncoated catheter }\end{array}$ & 1 & 162 & Risk Ratio (M-H, Fixed, 95\% CI) & $0.82[0.70,0.96]$ \\
\hline $\begin{array}{l}3 \text { Number reporting product } \\
\text { discretion }\end{array}$ & 2 & & Risk Ratio (M-H, Fixed, 95\% CI) & Subtotals only \\
\hline $\begin{array}{l}3.1 \text { Hydrophilic-coated versus } \\
\text { hydrophilic-coated }\end{array}$ & 2 & 132 & Risk Ratio (M-H, Fixed, 95\% CI) & $1.41[1.18,1.69]$ \\
\hline 4 Number reporting preference & 4 & & Risk Ratio (M-H, Fixed, 95\% CI) & Subtotals only \\
\hline $\begin{array}{l}\text { 4.1 Hydrophylic-coated versus } \\
\text { hydrophilic-coated }\end{array}$ & 1 & 47 & Risk Ratio (M-H, Fixed, 95\% CI) & $1.16[0.94,1.42]$ \\
\hline $\begin{array}{l}\text { 4.2 Uncoated catheter versus } \\
\text { uncoated catheter }\end{array}$ & 1 & 162 & Risk Ratio (M-H, Fixed, 95\% CI) & $0.09[0.05,0.19]$ \\
\hline $\begin{array}{l}4.3 \text { Hydrophilic-coated } \\
\text { versus various standard length } \\
\text { catheters }\end{array}$ & 2 & 296 & Risk Ratio (M-H, Fixed, 95\% CI) & $1.51[1.19,1.91]$ \\
\hline
\end{tabular}

Intermittent catheterisation for long-term bladder management (Review) 
Analysis I.I. Comparison I Aseptic technique versus clean/other aseptic technique, Outcome I Number with asymptomatic bacteriuria.

Review: Intermittent catheterisation for long-term bladder management

Comparison: I Aseptic technique versus clean/other aseptic technique

Outcome: I Number with asymptomatic bacteriuria

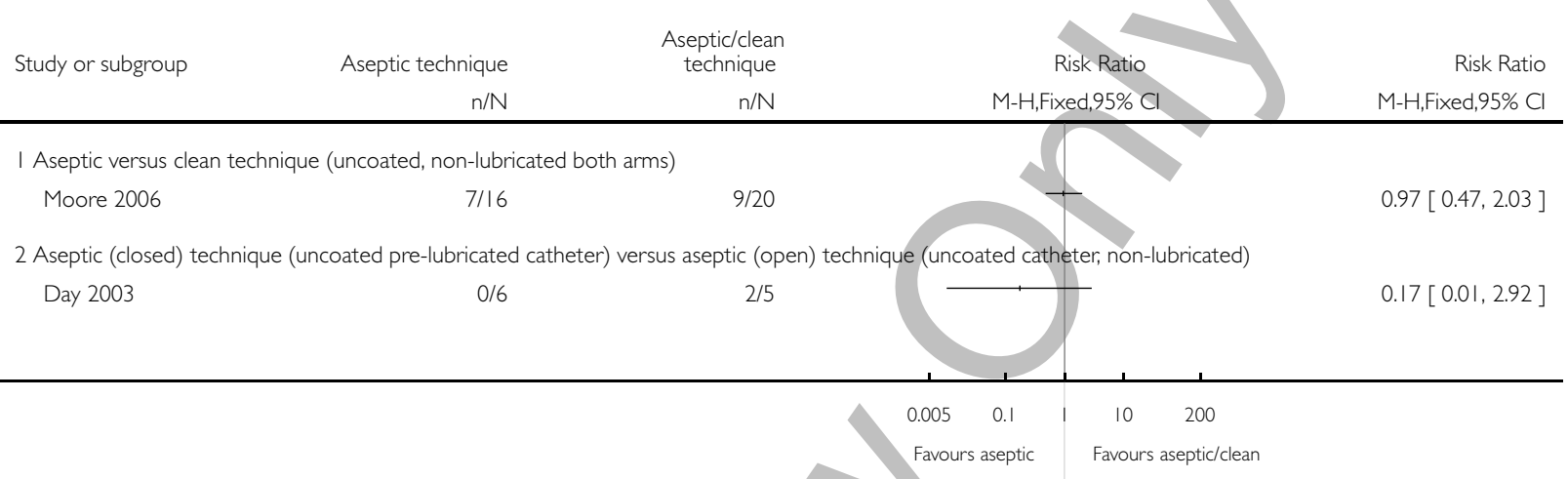


Analysis I.2. Comparison I Aseptic technique versus clean/other aseptic technique, Outcome 2 Number with symptomatic UTI.

Review: Intermittent catheterisation for long-term bladder management

Comparison: I Aseptic technique versus clean/other aseptic technique

Outcome: 2 Number with symptomatic UTI

\begin{tabular}{|c|c|c|c|c|c|}
\hline Study or subgroup & $\begin{array}{r}\text { Aseptic technique } \\
\mathrm{n} / \mathrm{N}\end{array}$ & $\begin{array}{r}\text { Aseptic/clean } \\
\text { technique } \\
n / N\end{array}$ & $\begin{array}{c}\text { Risk Ratio } \\
\text { M-H,Fixed,95\% Cl }\end{array}$ & ve & $\begin{array}{r}\text { Risk Ratio } \\
\text { M-H,Fixed,95\% Cl }\end{array}$ \\
\hline \multicolumn{6}{|c|}{ I Aseptic versus clean/other aseptic technique (uncoated catheter, non-lubricated both arms) } \\
\hline King 1992 & $5 / 23$ & $3 / 23$ & & $7.6 \%$ & $1.67[0.45,6.17]$ \\
\hline Duffy 1995 & 20/38 & $22 / 42$ & & $52.7 \%$ & $1.00[0.66,1.53]$ \\
\hline Prieto-Fingerhut 1999 & $9 / 14$ & $8 / 15$ & & $19.5 \%$ & $1.21[0.65,2.23]$ \\
\hline Moore 2006 & $6 / 16$ & $9 / 20$ & & $20.2 \%$ & $0.83[0.38,1.85]$ \\
\hline Subtotal $(95 \% \mathrm{CI})$ & 91 & 100 & & $100.0 \%$ & $1.06[0.77,1.45]$ \\
\hline \multicolumn{6}{|c|}{ Total events: 40 (Aseptic technique), 42 (Aseptic/clean technique) } \\
\hline \multicolumn{6}{|c|}{ Heterogeneity: Chi $^{2}=1.04, d f=3(P=0.79) ; 1^{2}=0.0 \%$} \\
\hline \multicolumn{6}{|c|}{ Test for overall effect: $Z=0.36(P=0.72)$} \\
\hline \multicolumn{6}{|c|}{2 Aseptic (closed) technique (uncoated pre-lubricated catheter) versus aseptic (open) technique (uncoated catheter, non-lubricated) } \\
\hline Quigley 1993 & $1 / 1 \mid$ & 17 & & $100.0 \%$ & $0.82[0.06,11.33]$ \\
\hline Subtotal $(95 \% \mathrm{CI})$ & 11 & & & $100.0 \%$ & $0.82[0.06,11.33]$ \\
\hline \multicolumn{6}{|c|}{ Total events: I (Aseptic technique), I (Aseptic/clean technique) } \\
\hline \multicolumn{6}{|c|}{ Heterogeneity: not applicable } \\
\hline \multicolumn{6}{|c|}{ Test for overall effect: $Z=0.15(P=0.88)$} \\
\hline & & & 10 & 50 & \\
\hline
\end{tabular}


Analysis I.3. Comparison I Aseptic technique versus clean/other aseptic technique, Outcome 3 Weeks to onset of symptomatic UTI.
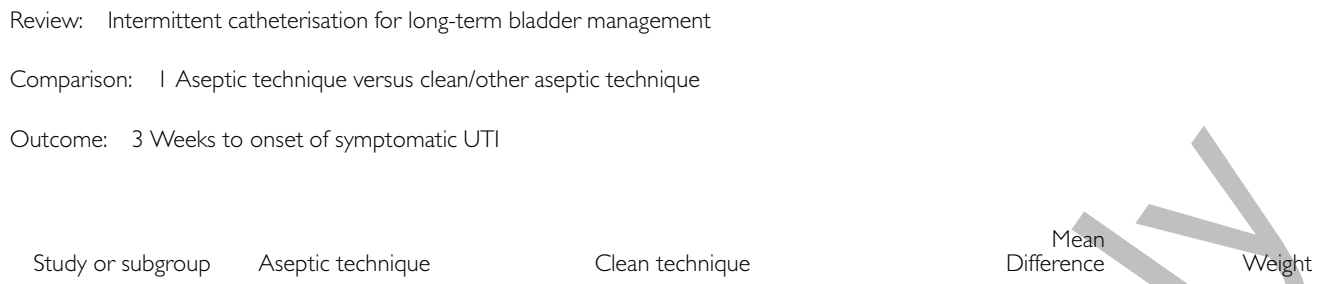

Mean

\begin{tabular}{lll}
$\mathrm{N} \operatorname{Mean}(\mathrm{SD})$ & $\mathrm{N}$ & Mean(SD) \\
\hline I Aseptic technique versus clean technique (uncoated catheter, non-lubricated both arms)
\end{tabular}

$$
\text { King } 1992
$$

$23-1.25(1.05)$

Duffy 1995

$42-3.11(3.12)$

Moore 2006

$16-4.6(3.3)$

81

Subtotal (95\% CI)

Heterogeneity: $\mathrm{Chi}^{2}=0.38, \mathrm{df}=2(\mathrm{P}=0.83) ; \mathrm{I}^{2}=0.0 \%$

Test for overall effect: $Z=0.58(P=0.56)$

Test for subgroup differences: Not applicable 


\section{Analysis 2.I. Comparison 2 Single-ise (sterile) catheter versus multiple-use (clean) catheter, Outcome I Number with asymptomatic bacteriuria.}

Review: Intermittent catheterisation for long-term bladder management

Comparison: 2 Single-ise (sterile) catheter versus multiple-use (clean) catheter

Outcome: I Number with asymptomatic bacteriuria

Study or subgroup

Single use Multiple use

$\mathrm{n} / \mathrm{N}$

I Uncoated catheter, non-lubricated and clean technique both arms

$\begin{array}{lll}\text { Moore } 1993 & 17 / 33 & 16 / 33\end{array}$

Schlager 2001

$10 / 10$

$9 / 10$

Leek 2013

$4 / 12$

$4 / 10$

55

53

53

Subtotal $(95 \% \mathrm{CI})$

Total events: 31 (Single use), 29 (Multiple use)
Heterogeneity: Tau $^{2}=0.0 ; \mathrm{Chi}^{2}=0.35, \mathrm{df}=2(\mathrm{P}=0.84) ; \mathrm{I}^{2}=0.0 \%$

Test for overall effect: $Z=0.68(P=0.50)$

2 Hydrophilic-coated catheter, not activated (single-use arm, clean technique) versus uncoated catheter, non-lubricated (multi use arm, clean technique)
Pachler 1999
$13 / 32$
$16 / 32$
$100.0 \%$
$0.81[0.47,1.40]$
Subtotal (95\% CI)
32
32
$\longrightarrow \longrightarrow$
$100.0 \%$
$0.81[0.47,1.40]$

Total events: 13 (Single use), 16 (Multiple use)

Heterogeneity: not applicable

Test for overall effect: $Z=0.75(P=0.45)$

Test for subgroup differences: $C^{2}{ }^{2}=0.91, \mathrm{df}=I(P=0.34), I^{2}=0.0 \%$

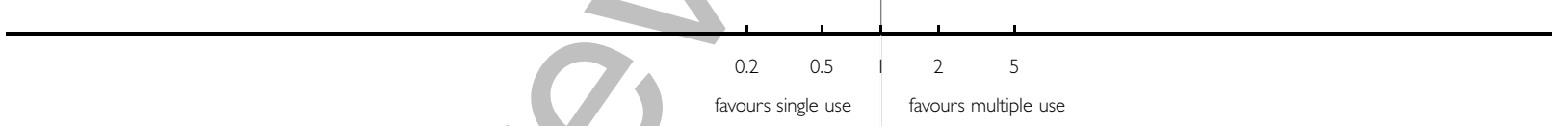




\section{Analysis 2.2. Comparison 2 Single-ise (sterile) catheter versus multiple-use (clean) catheter, Outcome 2 Number with symptomatic UTI.}

Review: Intermittent catheterisation for long-term bladder management

Comparison: 2 Single-ise (sterile) catheter versus multiple-use (clean) catheter

Outcome: 2 Number with symptomatic UTI

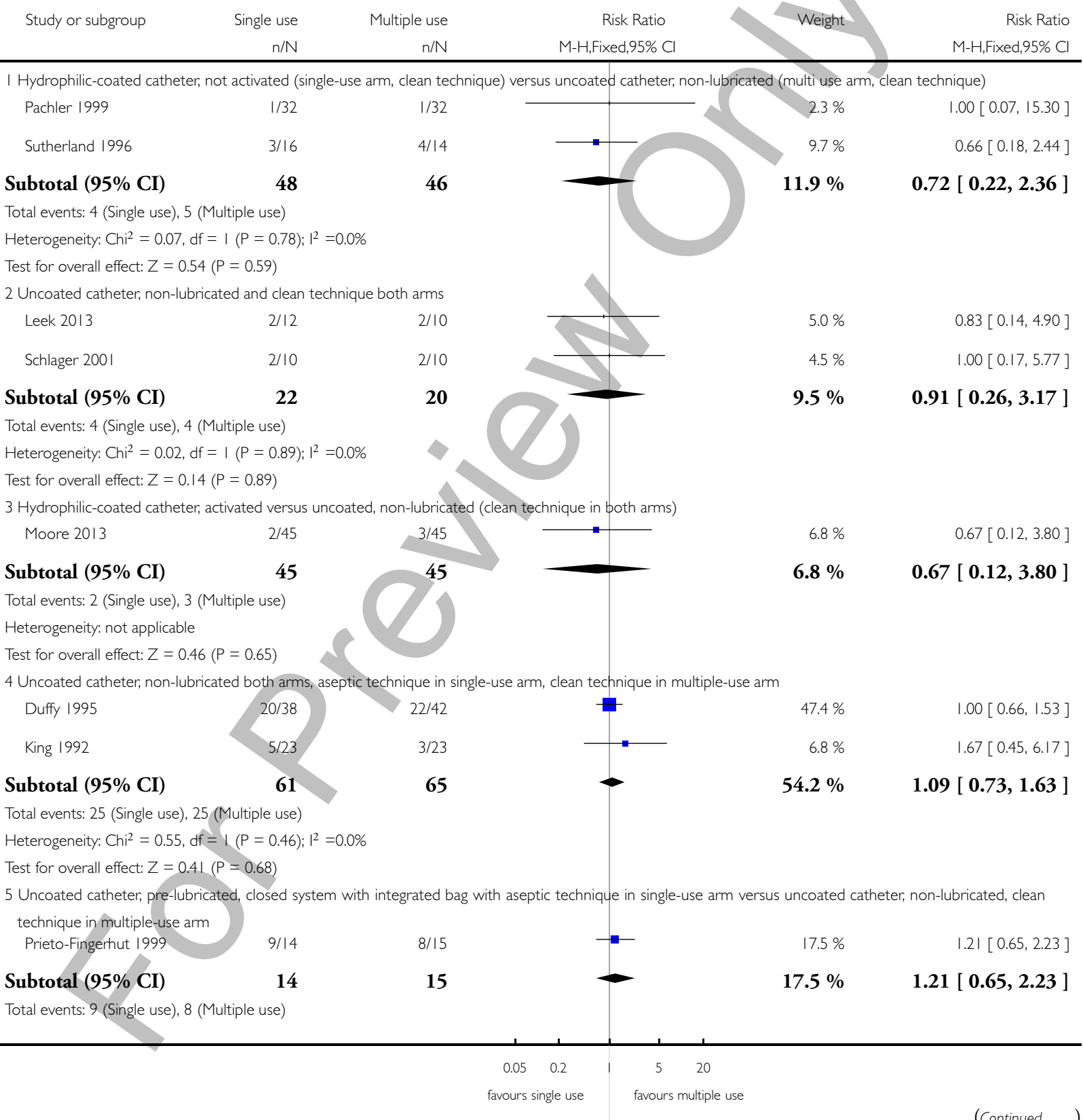




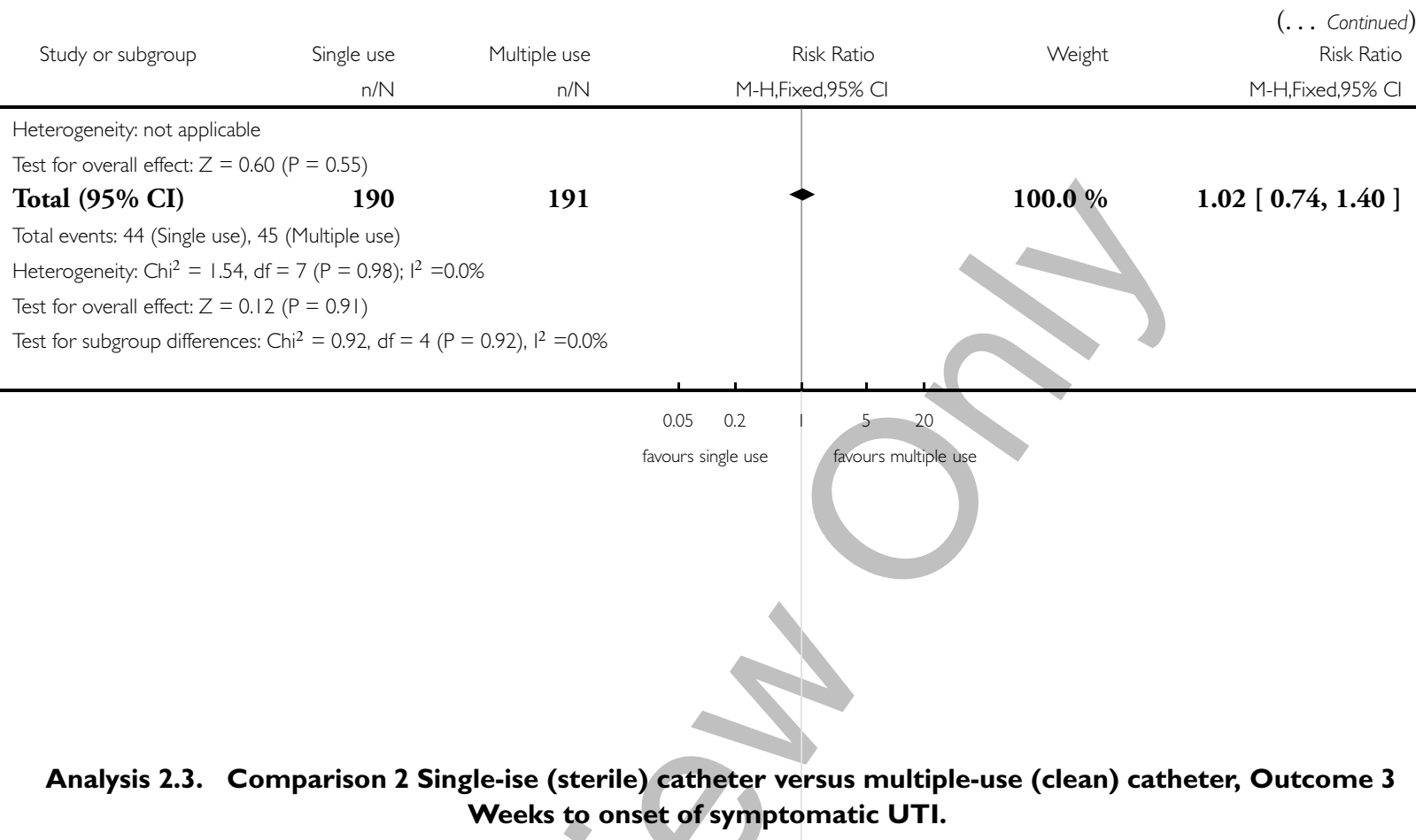

Review: Intermittent catheterisation for long-term bladder management

Comparison: 2 Single-ise (sterile) catheter versus multiple-use (clean) catheter

Outcome: 3 Weeks to onset of symptomatic UTI

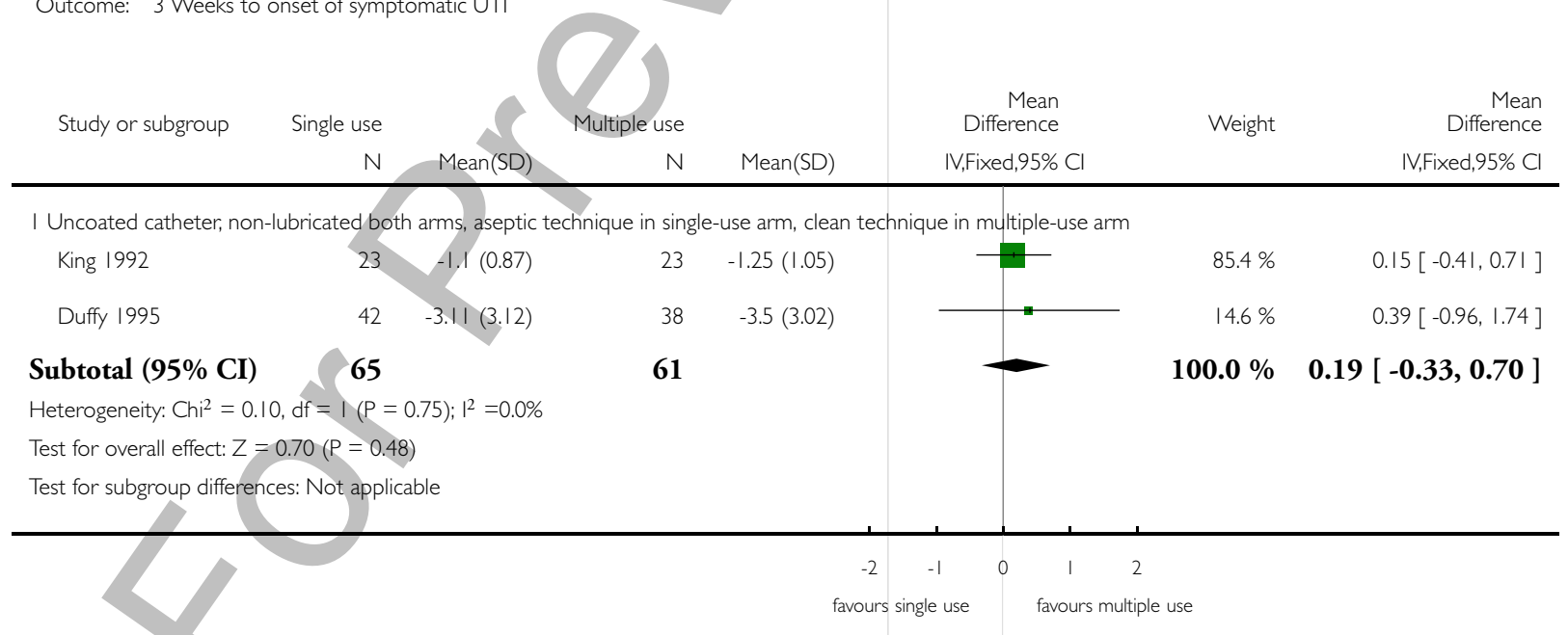


Analysis 2.4. Comparison 2 Single-ise (sterile) catheter versus multiple-use (clean) catheter, Outcome 4 Number with microscopic haematuria.

Review: Intermittent catheterisation for long-term bladder management

Comparison: 2 Single-ise (sterile) catheter versus multiple-use (clean) catheter

Outcome: 4 Number with microscopic haematuria

\begin{tabular}{rrr} 
Single use & Multiple use & Risk Ratio \\
$\mathrm{n} / \mathrm{N}$ & $\mathrm{n} / \mathrm{N}$ & $\mathrm{M}-\mathrm{H}, \mathrm{Fixed}, 95 \% \mathrm{Cl}$ \\
\hline
\end{tabular}

I Hydrophilic-coated catheter, not activated, water added by user (single-use arm, clean technique) versus uncoated catheter, non-lubricated (multi use arm, clean technique)

Sutherland $1996 \quad 6 / 16 \quad 11 / 14$

\section{4}

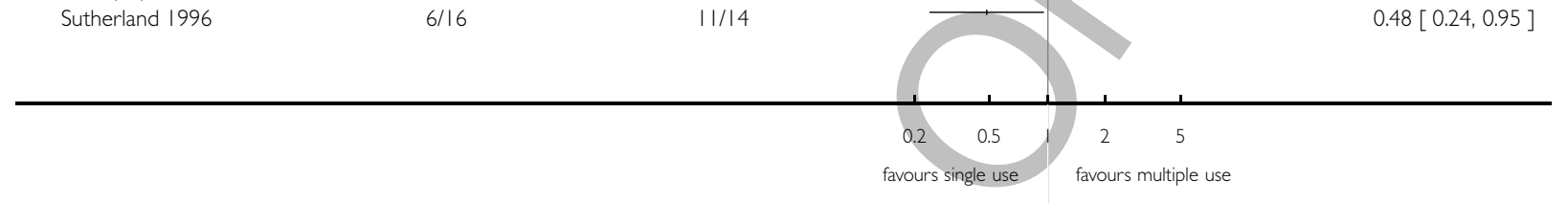

$+$

$0.48[0.24,0.95]$

Analysis 2.5. Comparison 2 Single-ise (sterile) catheter versus multiple-use (clean) catheter, Outcome 5 Number with urethral trauma/bleeding/macroscopic haematuria.

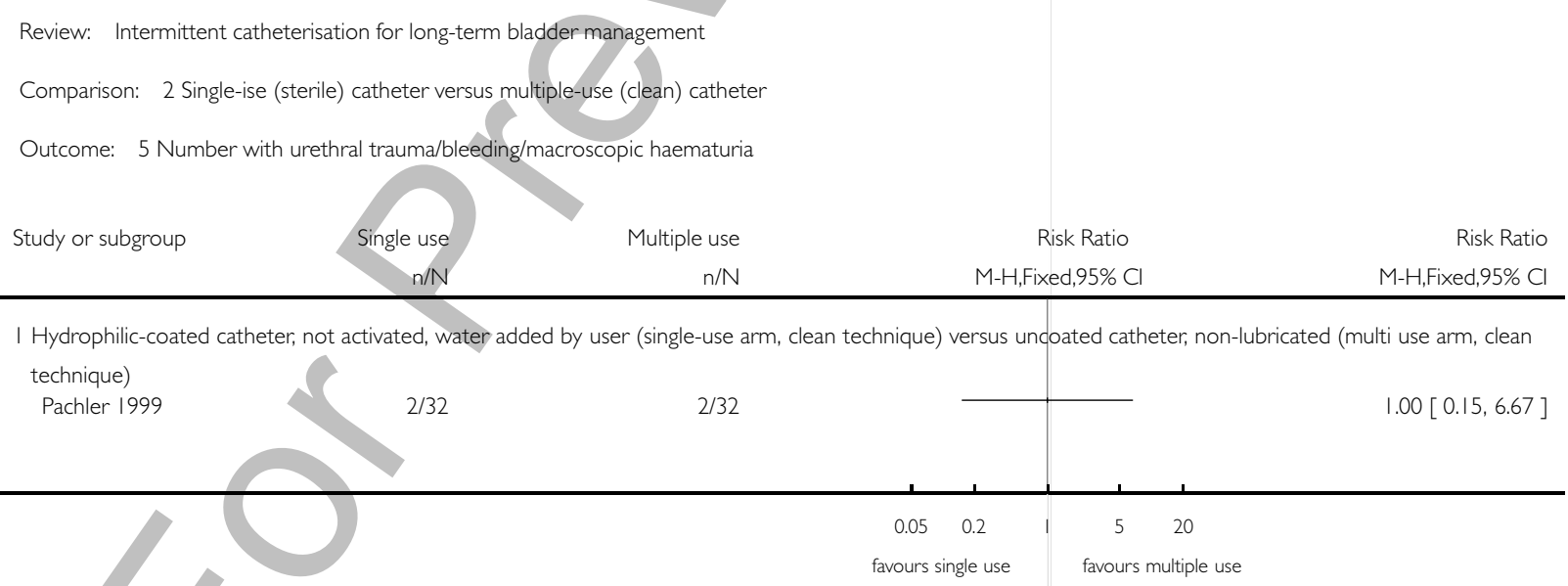


Analysis 2.6. Comparison 2 Single-ise (sterile) catheter versus multiple-use (clean) catheter, Outcome 6 Number reporting overall satisfaction.

Review: Intermittent catheterisation for long-term bladder management

Comparison: 2 Single-ise (sterile) catheter versus multiple-use (clean) catheter

Outcome: 6 Number reporting overall satisfaction

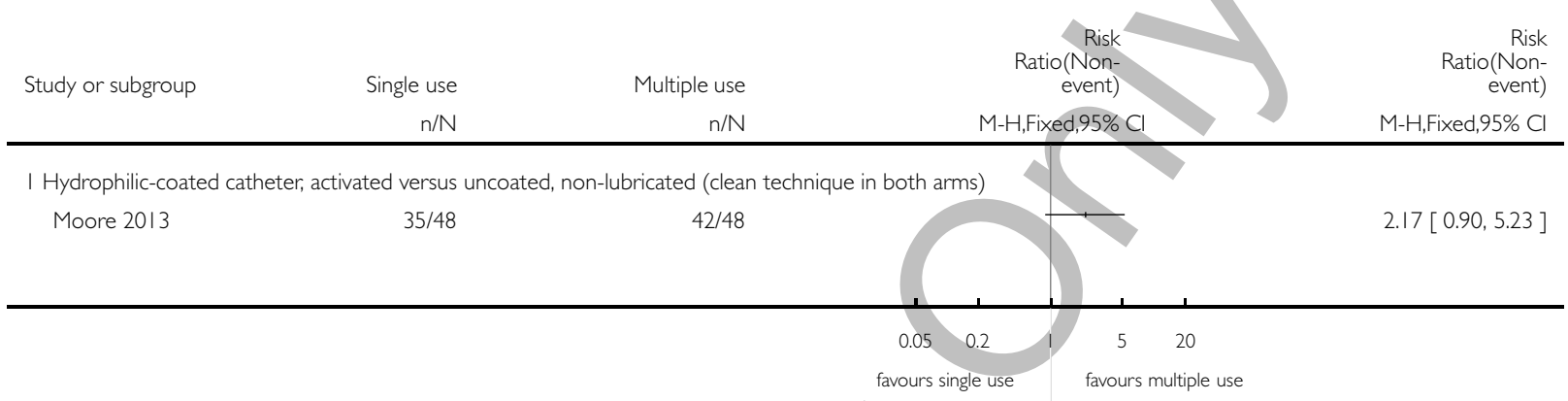

Analysis 2.7. Comparison 2 Single-ise (sterile) catheter versus multiple-use (clean) catheter, Outcome 7

\section{Mean satisfaction.}

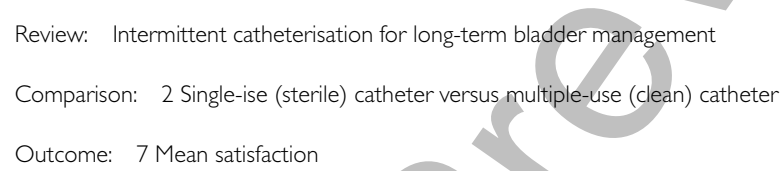

Outcome: 7 Mean satisfaction

$\begin{array}{lrr} & \text { Mean } & \text { Mean } \\ \text { Study or subgroup } \quad \text { Single use } & \text { Multiple use }\end{array}$

$\begin{array}{lllll}\mathrm{N} & \mathrm{M} & \mathrm{N} & \mathrm{Mean}(\mathrm{SD}) & \mathrm{N} \text {,Fixed,95\% Cl }\end{array}$

I Hydrophilic-coated catheter, not activated, water added by user (single-use arm, clean technique) versus uncoated catheter, non-lubricated (multi use arm, clean technique)

Sutherland $1996-17 \quad-4.1(2.5) \quad 16 \quad-3.6(2.1)$

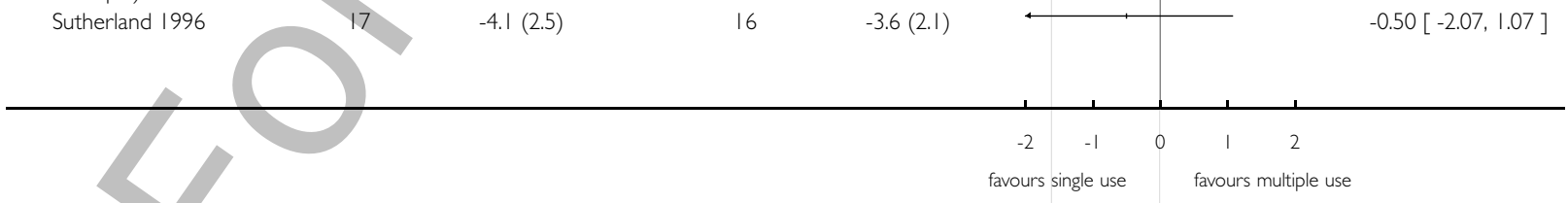




\section{Analysis 2.8. Comparison 2 Single-ise (sterile) catheter versus multiple-use (clean) catheter, Outcome 8} Number reporting ease of handling.

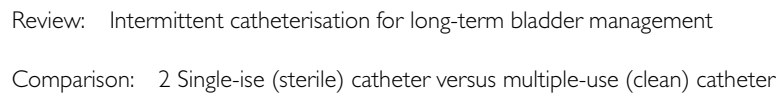

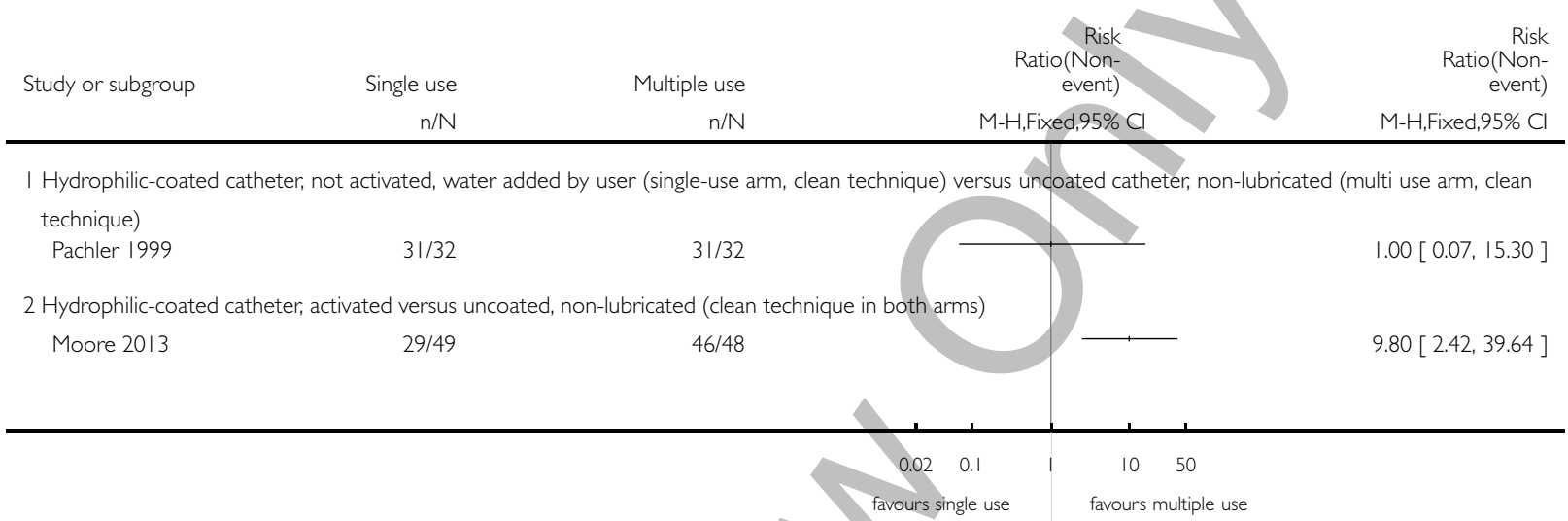

Analysis 2.9. Comparison 2 Single-ise (sterile) catheter versus multiple-use (clean) catheter, Outcome 9 Mean ease of handling.

Review: Intermittent catheterisation for long-term bladder management

Comparison: 2 Single-ise (sterile) catheter versus multiple-use (clean) catheter

Outcome: 9 Mean ease of handling

\begin{tabular}{|c|c|c|c|c|c|}
\hline \multirow[t]{2}{*}{ Study or subgroup } & \multicolumn{3}{|c|}{ Multiple use } & \multirow{2}{*}{$\begin{array}{c}\text { Mean } \\
\text { Difference } \\
\text { IV,Fixed,95\% Cl }\end{array}$} & \multirow{2}{*}{$\begin{array}{r}\text { Mean } \\
\text { Difference } \\
\text { IV,Fixed,95\% Cl }\end{array}$} \\
\hline & Mean(SD) & $\mathrm{N}$ & Mean(SD) & & \\
\hline
\end{tabular}

I Hydrophilic-coated catheter, not activated, water added by user (single-use arm, clean technique) versus uncoated catheter, non-lubricated (multi use arm, clean technique)
Sutherland 1996
17
$-3.6(2.5)$
16
$-3.5(2.8)$

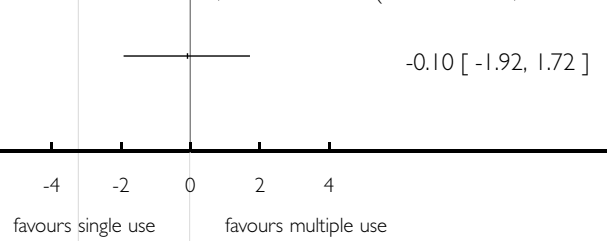


Analysis 2.10. Comparison 2 Single-ise (sterile) catheter versus multiple-use (clean) catheter, Outcome 10 Number reporting ease of insertion.

Review: Intermittent catheterisation for long-term bladder management

Comparison: 2 Single-ise (sterile) catheter versus multiple-use (clean) catheter

Outcome: 10 Number reporting ease of insertion

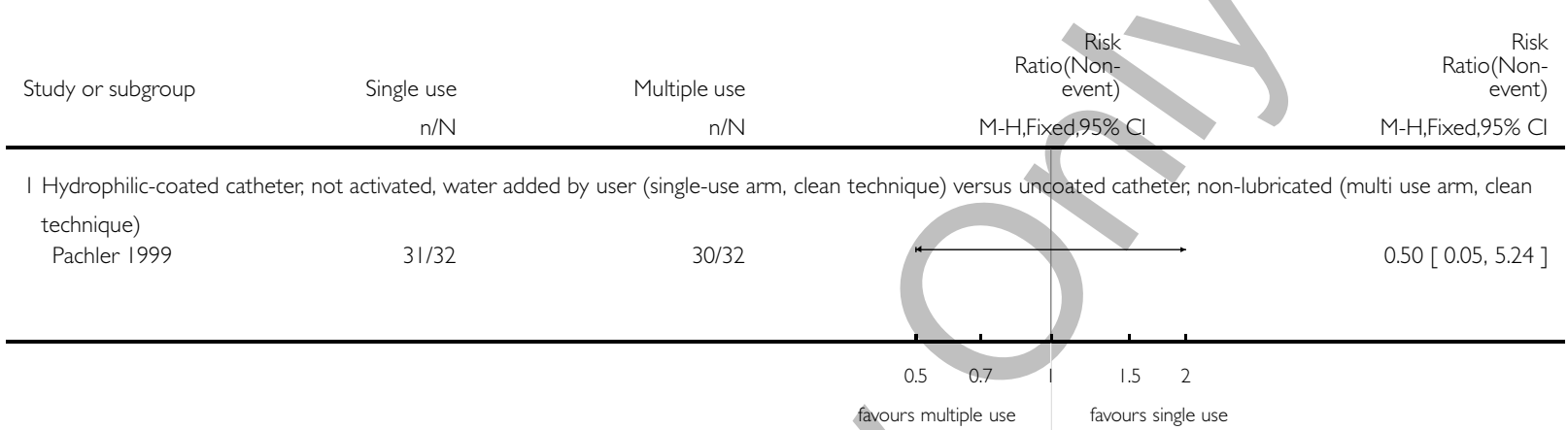

Analysis 2.I I. Comparison 2 Single-ise (sterile) catheter versus multiple-use (clean) catheter, Outcome I I Mean ease of insertion.

Review: Intermittent catheterisation for long-term bladder management

Comparison: 2 Single-ise (sterile) catheter versus multiple-use (clean) catheter

Outcome: II Mean ease of insertion

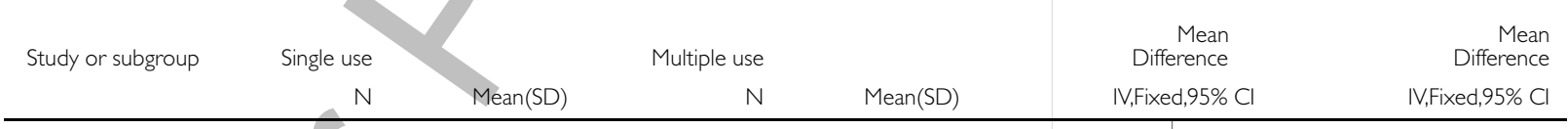

I Hydrophilic-coated catheter, not activated, water added by user (single-use arm, clean technique) versus uncoated catheter, non-lubricated (multi use arm, clean technique)

$\begin{array}{lllll}\text { Sutherland } 1996 & 17 & -3.6(2.6) & 16 & -3.6(2.5)\end{array}$

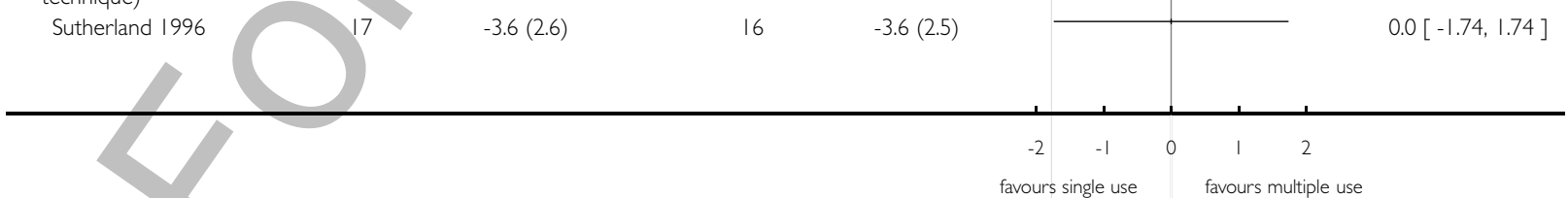




\section{Analysis 2.12. Comparison 2 Single-ise (sterile) catheter versus multiple-use (clean) catheter, Outcome 12} Number reporting comfort.

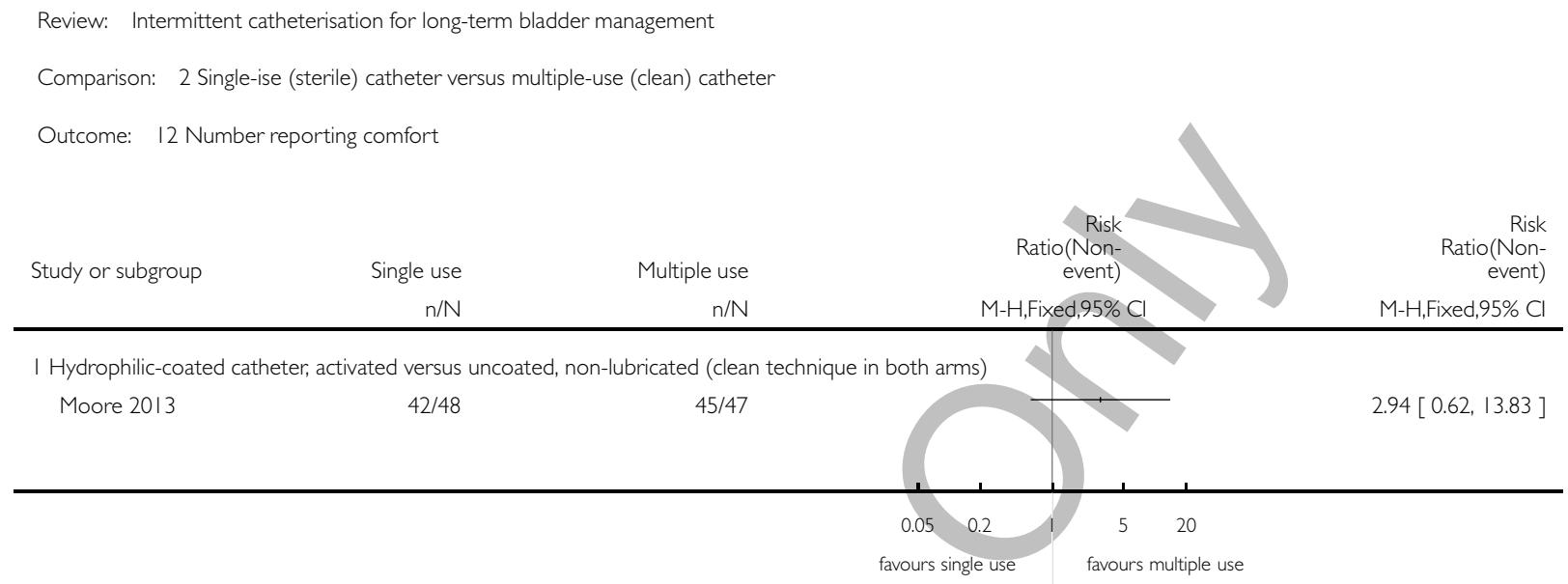

Analysis 2.13. Comparison 2 Single-ise (sterile) catheter versus multiple-use (clean) catheter, Outcome 13 Number reporting convenience of product.

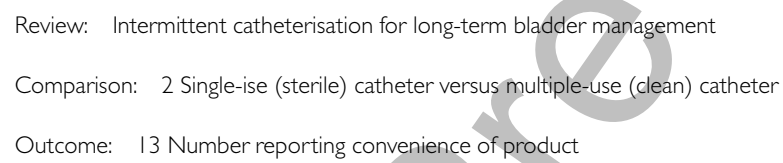

I Hydrophilic-coated catheter, activated versus uncoated, non-lubricated (clean technique in both arms)

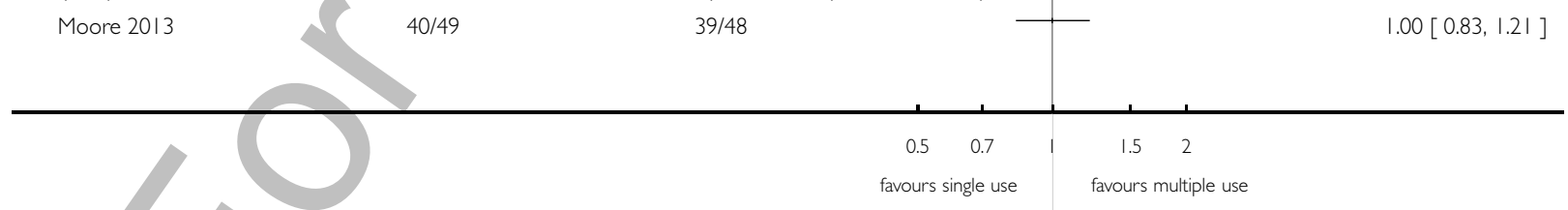




\section{Analysis 2.14. Comparison 2 Single-ise (sterile) catheter versus multiple-use (clean) catheter, Outcome I4 Mean convenience of product.}

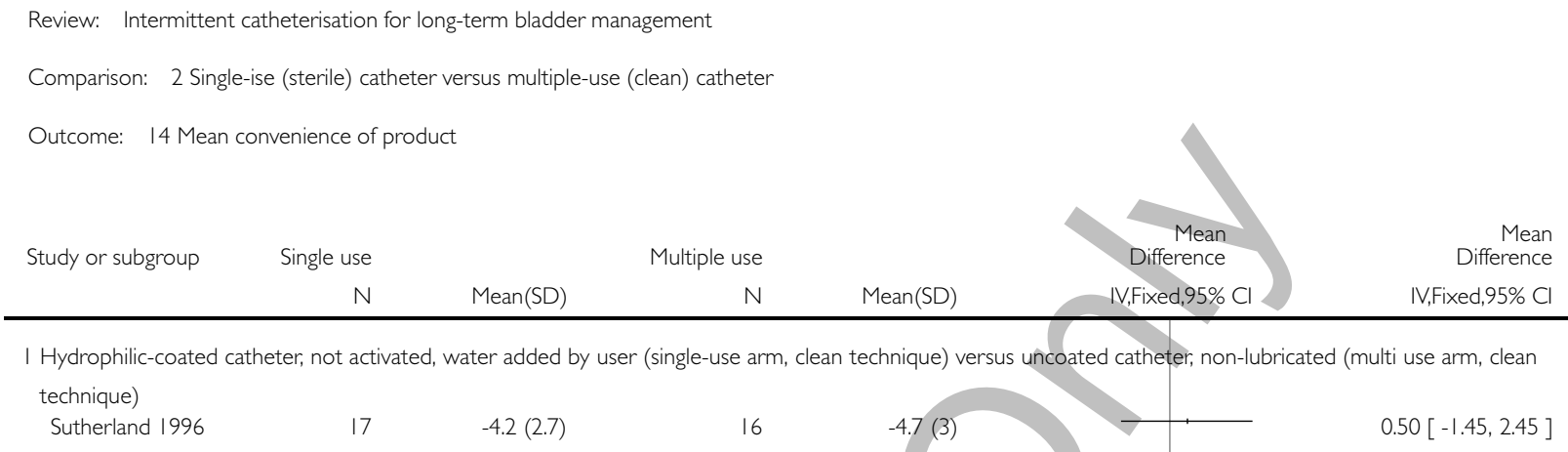

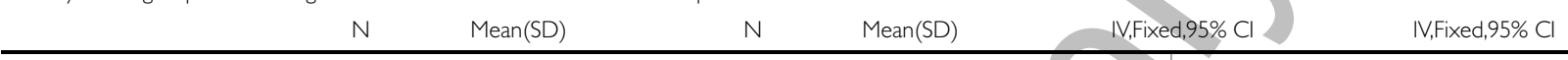

I Hydrophilic-coated catheter, not activated, water added by user (single-use arm, clean technique) versus uncoated catheter, non-lubricated (multi use arm, clean technique)

Sutherland 1996

17

$-4.2(2.7)$

16

$0.50[-1.45,2.45]$

Analysis 3.I. Comparison 3 Hydrophilic-coated or other pre-lubricated catheter versus other catheter (prelubricated, coated or uncoated), Outcome I Number with asymptomatic bacteriuria.

Review: Intermittent catheterisation for long-term bladder management

Comparison: 3 Hydrophilic-coated or other pre-lubricated catheter versus other catheter (pre-lubricated, coated or uncoated)

Outcome: I Number with asymptomatic bacteriuria

\begin{tabular}{rrrr} 
Study or subgroup & Catheter A & Catheter B & Risk Ratio \\
$n / N$ & $n / N$ & $M-H, F i x e d, 95 \% ~ C l$ & $M-H, F i x e d, 95 \%$ Cl \\
\hline
\end{tabular}

I Hydrophilic-coated catheter (not activated, water added by user) single use versus uncoated, non-lubricated, water-soluble gel added by user, multiple use

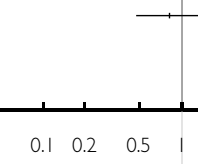


Analysis 3.2. Comparison 3 Hydrophilic-coated or other pre-lubricated catheter versus other catheter (prelubricated, coated or uncoated), Outcome 2 Number with symptomatic UTI.

Review: Intermittent catheterisation for long-term bladder management

Comparison: 3 Hydrophilic-coated or other pre-lubricated catheter versus other catheter (pre-lubricated, coated or uncoated)

Outcome: 2 Number with symptomatic UTI

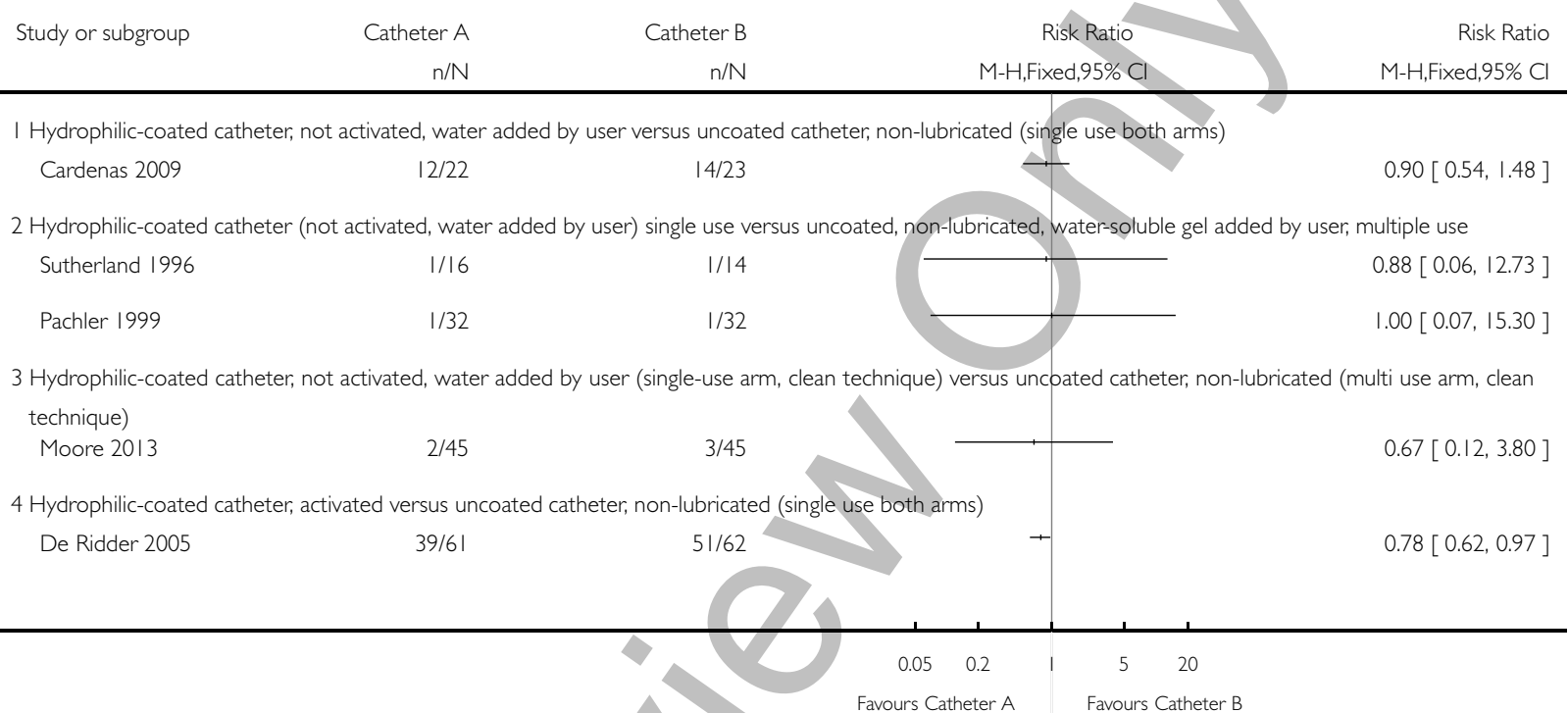

Analysis 3.3. Comparison 3 Hydrophilic-coated or other pre-lubricated catheter versus other catheter (prelubricated, coated or uncoated), Outcome 3 Number of UTIs per month of use.

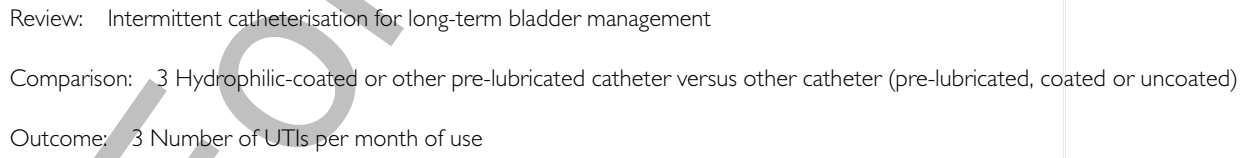

I Hydrophilic-coated catheter, activated versus uncoated catheter, non-lubricated (single use both arms) 
Analysis 3.4. Comparison 3 Hydrophilic-coated or other pre-lubricated catheter versus other catheter (prelubricated, coated or uncoated), Outcome 4 Number with urethral trauma/bleeding/macroscopic haematuria.

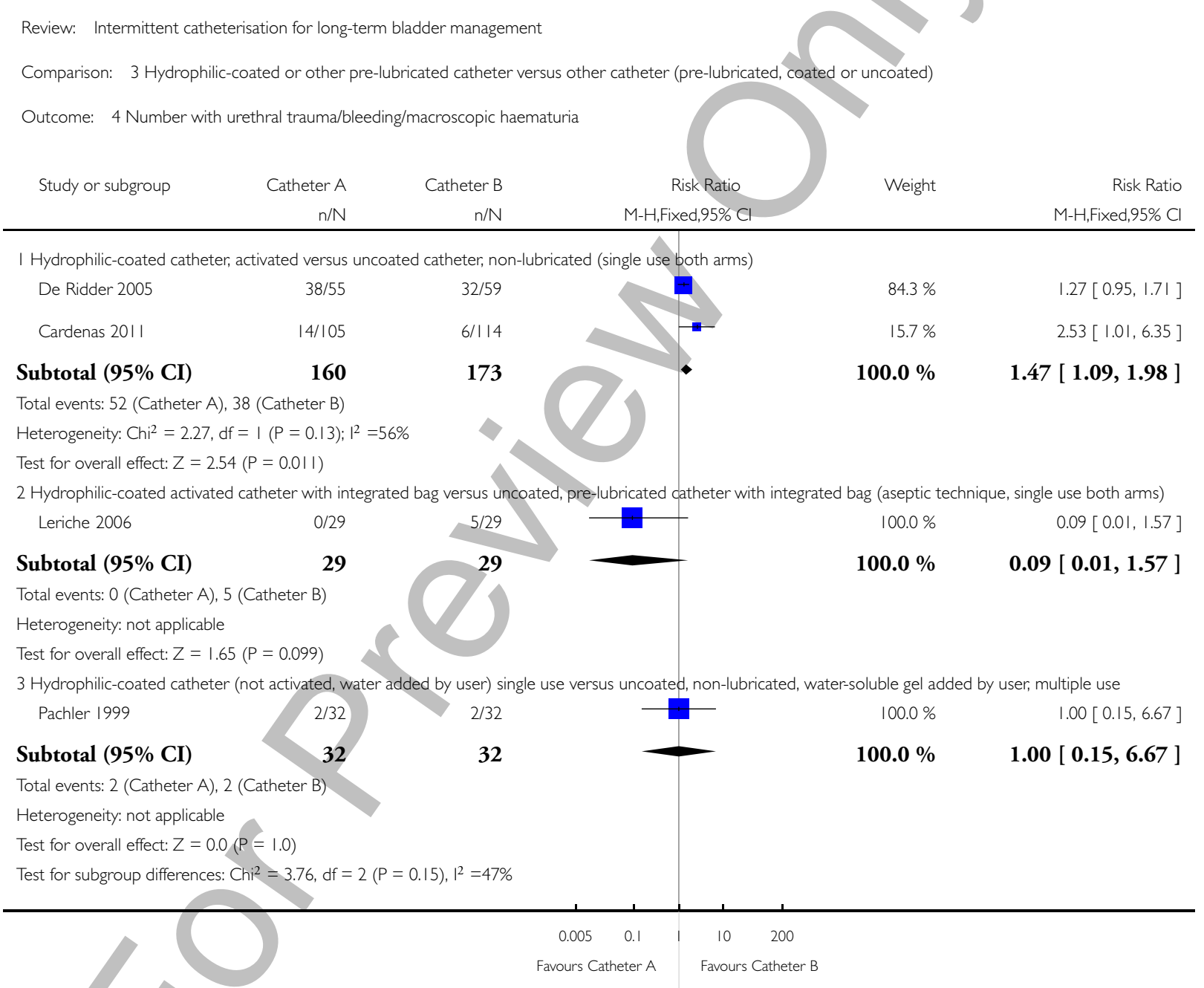


Analysis 3.5. Comparison 3 Hydrophilic-coated or other pre-lubricated catheter versus other catheter (prelubricated, coated or uncoated), Outcome 5 Number with microscopic haematuria.

Review: Intermittent catheterisation for long-term bladder management

Comparison: 3 Hydrophilic-coated or other pre-lubricated catheter versus other catheter (pre-lubricated, coated or uncoated)

Outcome: 5 Number with microscopic haematuria

\begin{tabular}{rrr} 
Catheter A & Catheter B & Risk Ratio \\
$\mathrm{n} / \mathrm{N}$ & $\mathrm{n} / \mathrm{N}$ & $\mathrm{M}-\mathrm{H}, \mathrm{Fixed}, 95 \% \mathrm{Cl}$ \\
\hline
\end{tabular}

I Hydrophilic-coated catheter, not activated, water added by user (single-use arm, clean technique) versus uncoated catheter, non-lubricated (multi use arm, clean technique)

Sutherland 1996

$6 / 16$

$1|/| 4$

$0.48[0.24,0.95]$

Analysis 3.6. Comparison 3 Hydrophilic-coated or other pre-lubricated catheter versus other catheter (prelubricated, coated or uncoated), Outcome 6 Mean microscopic haematuria.

Review: Intermittent catheterisation for long-term bladder management

Comparison: 3 Hydrophilic-coated or other pre-lubricated catheter versus other catheter (pre-lubricated, coated or uncoated)

Outcome: 6 Mean microscopic haematuria

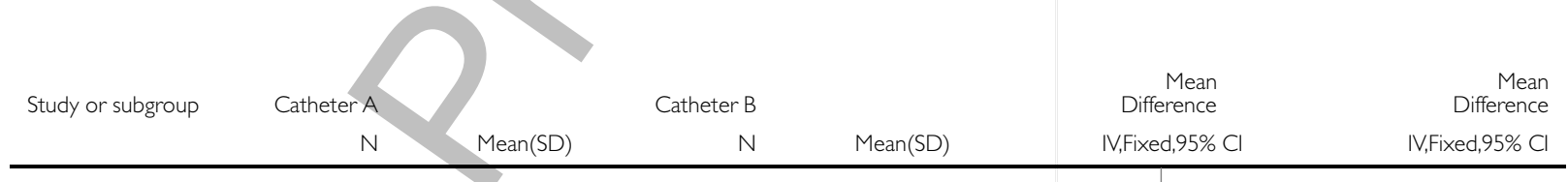

I Hydrophilic-coated catheter, not activated, water added by user (single-use arm, clean technique) versus uncoated catheter, non-lubricated (multi use arm, clean technique)

Moore 2013

$21 \quad 1.86(2.67)$

24

$3.25(6.05)$

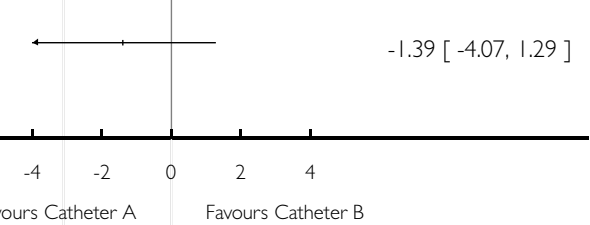


Analysis 3.7. Comparison 3 Hydrophilic-coated or other pre-lubricated catheter versus other catheter (prelubricated, coated or uncoated), Outcome 7 Number with stricture formation.

Review: Intermittent catheterisation for long-term bladder management

Comparison: 3 Hydrophilic-coated or other pre-lubricated catheter versus other catheter (pre-lubricated, coated or uncoated)

Outcome: 7 Number with stricture formation

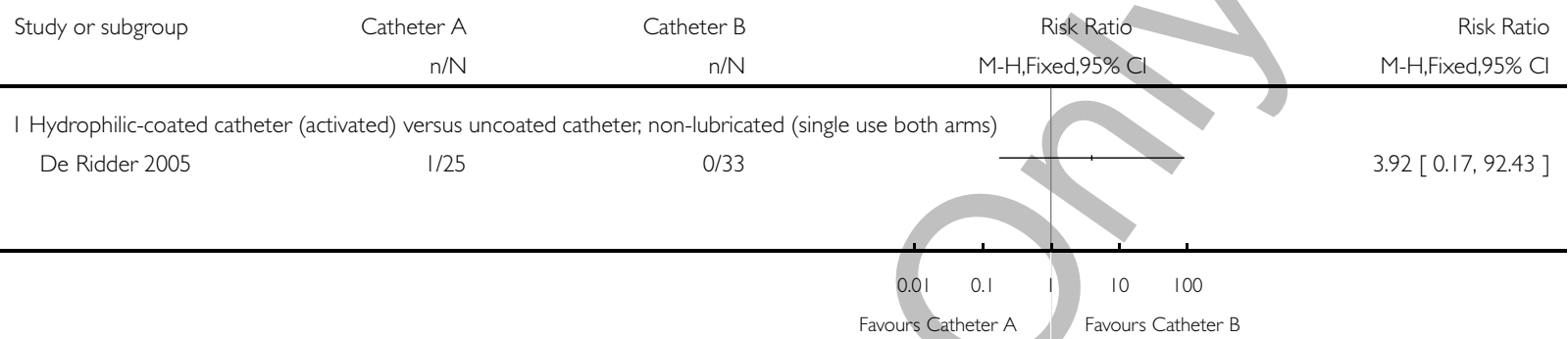

Analysis 3.8. Comparison 3 Hydrophilic-coated or other pre-lubricated catheter versus other catheter (prelubricated, coated or uncoated), Outcome 8 Number reporting overall satisfaction.
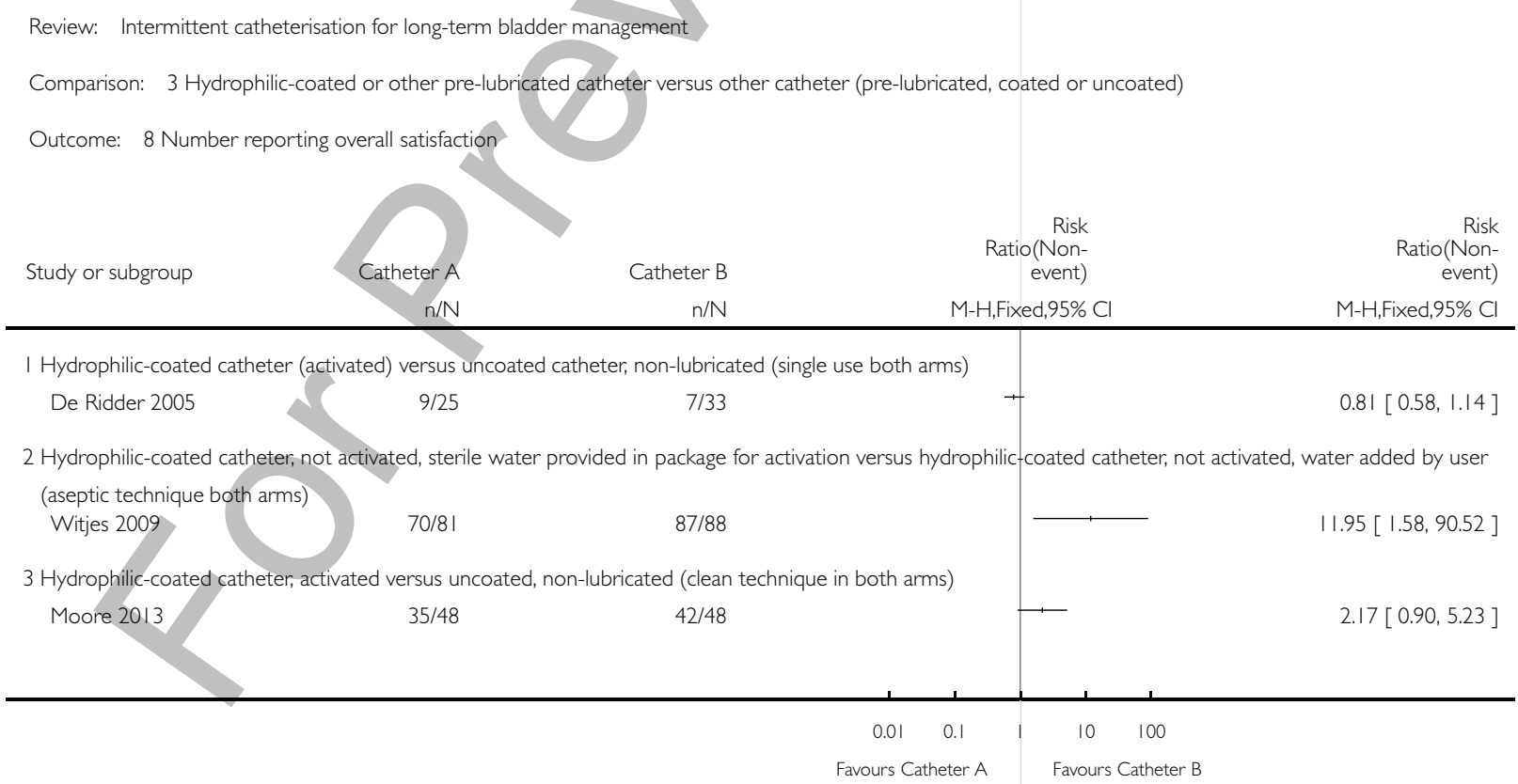


\section{Analysis 3.9. Comparison 3 Hydrophilic-coated or other pre-lubricated catheter versus other catheter (pre-} lubricated, coated or uncoated), Outcome 9 Mean Overall satisfaction.

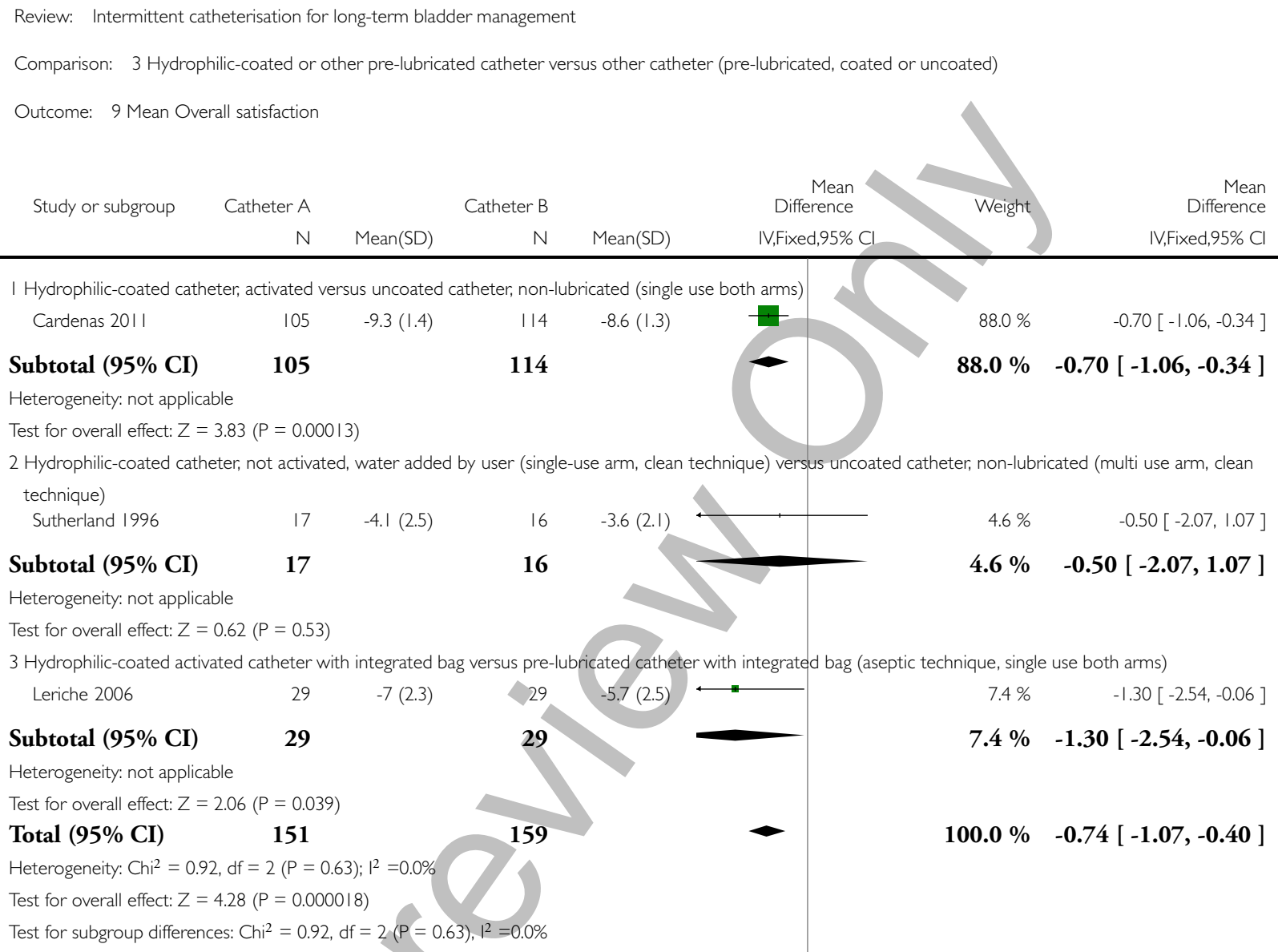

Subtotal $(95 \%$ CI $)$

29

29

$7.4 \%$

$-1.30[-2.54,-0.06]$

Heterogeneity: not applicable

Test for overall effect: $Z=2.06(P=0.039)$

Total (95\% CI)

151

Heterogeneity: $\mathrm{Chi}^{2}=0.92, \mathrm{df}=2(\mathrm{P}=0.63) ; \mathrm{I}^{2}=0.0 \%$

Test for overall effect: $Z=4.28(P=0.0000 \mid 8)$

Test for subgroup differences: $C h i^{2}=0.92, \mathrm{df}=2(P=0.63), \mathrm{I}^{2}=0.0 \%$ 
Analysis 3.10. Comparison 3 Hydrophilic-coated or other pre-lubricated catheter versus other catheter (pre-lubricated, coated or uncoated), Outcome 10 Number reporting preference.

Review: Intermittent catheterisation for long-term bladder management

Comparison: 3 Hydrophilic-coated or other pre-lubricated catheter versus other catheter (pre-lubricated, coated or uncoated)

Outcome: 10 Number reporting preference

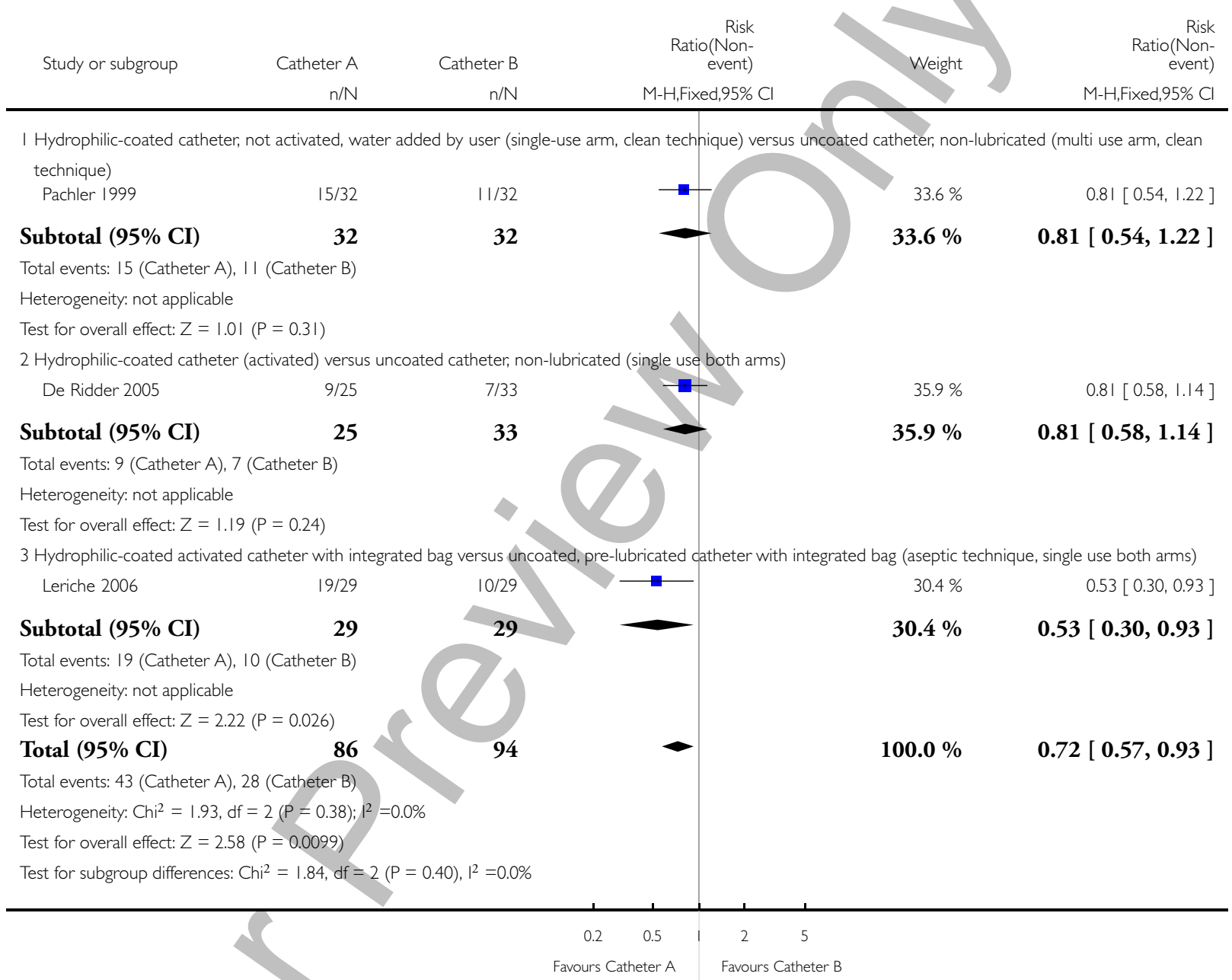


Analysis 3.I I. Comparison 3 Hydrophilic-coated or other pre-lubricated catheter versus other catheter (pre-lubricated, coated or uncoated), Outcome I I Number reporting convenience of product.

Review: Intermittent catheterisation for long-term bladder management

Comparison: 3 Hydrophilic-coated or other pre-lubricated catheter versus other catheter (pre-lubricated, coated or uncoated)

Outcome: II Number reporting convenience of product

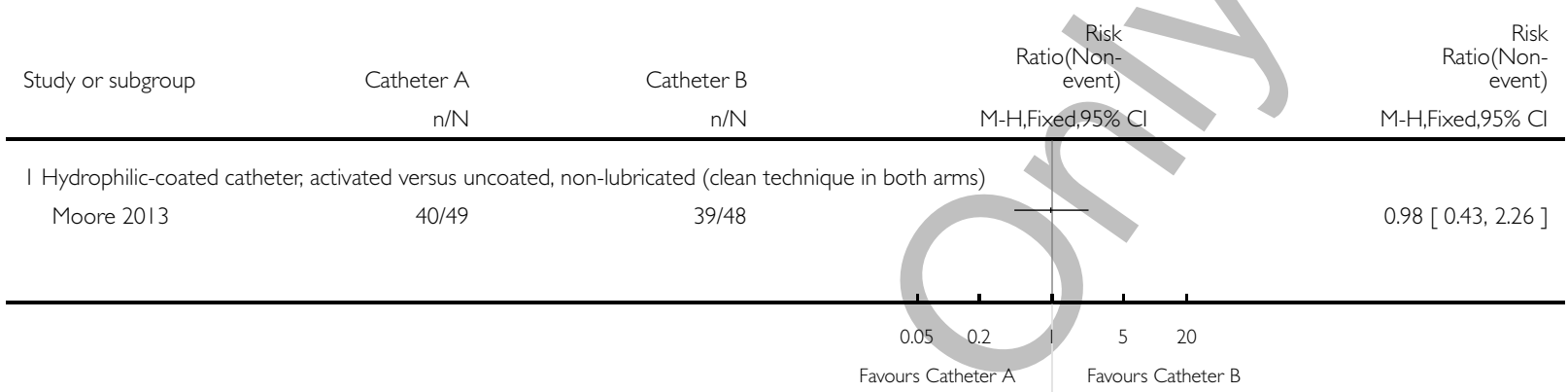

Analysis 3.12. Comparison 3 Hydrophilic-coated or other pre-lubricated catheter versus other catheter (pre-lubricated, coated or uncoated), Outcome 12 Mean convenience of product.

Review: Intermittent catheterisation for long-term bladder management

Comparison: 3 Hydrophilic-coated or other pre-lubricated catheter versus other catheter (pre-lubricated, coated or uncoated)

Outcome: 12 Mean convenience of product

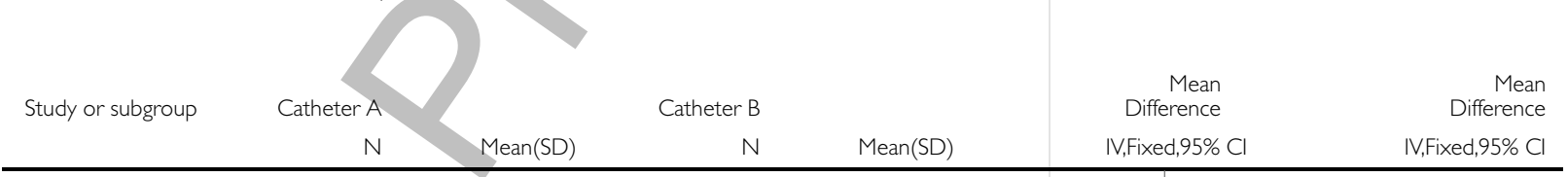

I Hydrophilic-coated catheter, not activated, water added by user (single-use arm, clean technique) versus uncoated catheter, non-lubricated (multi use arm, clean technique)

Sutherland 1996

$-4.2(2.7)$

16

$-4.7(3)$

$0.50[-1.45,2.45]$ 
Analysis 3.13. Comparison 3 Hydrophilic-coated or other pre-lubricated catheter versus other catheter (pre-lubricated, coated or uncoated), Outcome 13 Number reporting ease of handling.
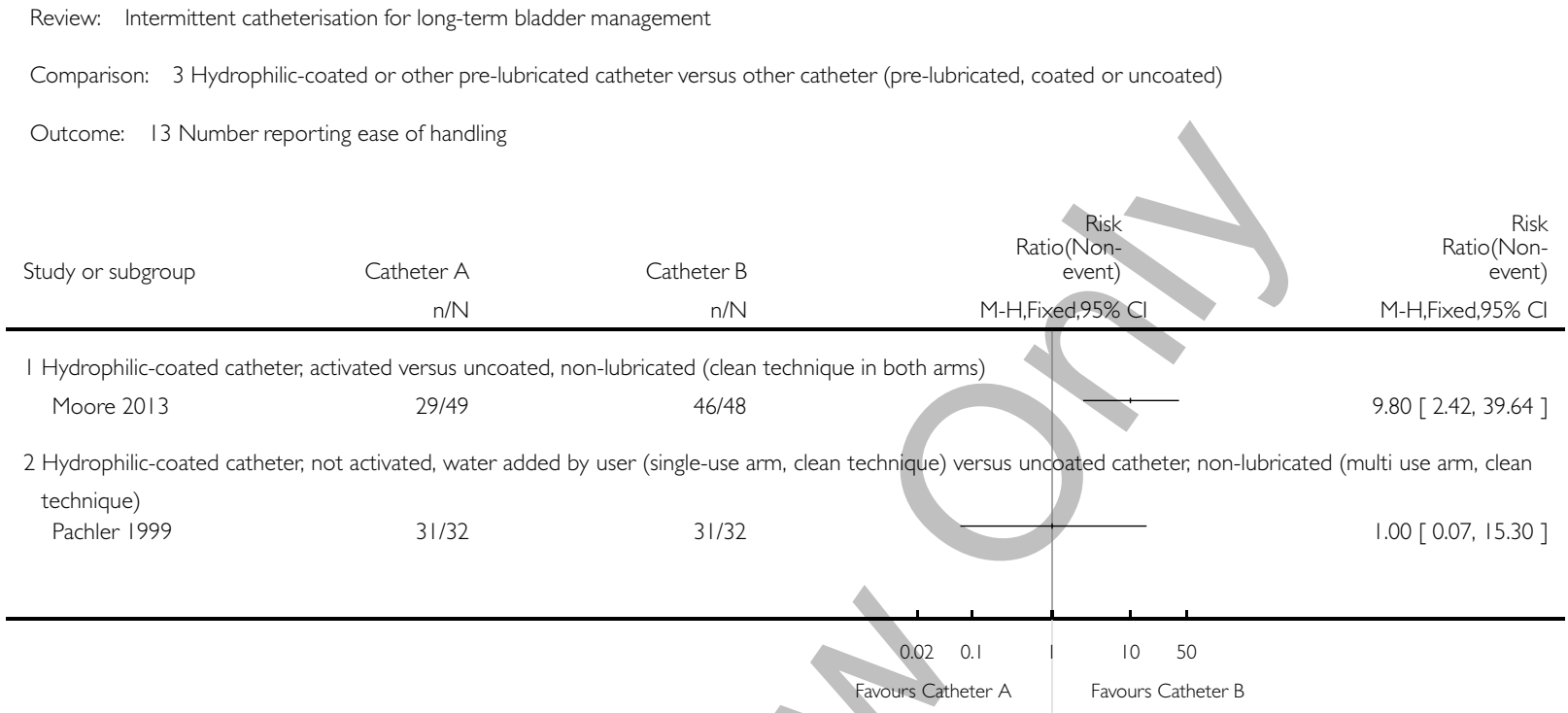

Analysis 3.14. Comparison 3 Hydrophilic-coated or other pre-lubricated catheter versus other catheter (pre-lubricated, coated or uncoated), Outcome 14 Mean ease of handling.

Review: Intermittent catheterisation for long-term bladder management

Comparison: 3 Hydrophilic-coated or other pre-lubricated catheter versus other catheter (pre-lubricated, coated or uncoated)

Outcome: 14 Mean ease of handling

\begin{tabular}{rrrr} 
Catheter A & Mean(SD) & Catheter B & $\begin{array}{r}\text { Mean } \\
\text { Difference }\end{array}$ \\
IV,Fixed,95\% Cl & $\mathrm{N}$ & Mean(SD) & IV,Fixed,95\% Cl \\
\hline
\end{tabular}

I Hydrophilic-coated catheter, not activated, water added by user (single-use arm, clean technique) versus uncoated catheter, non-lubricated (multi use arm, clean technique)

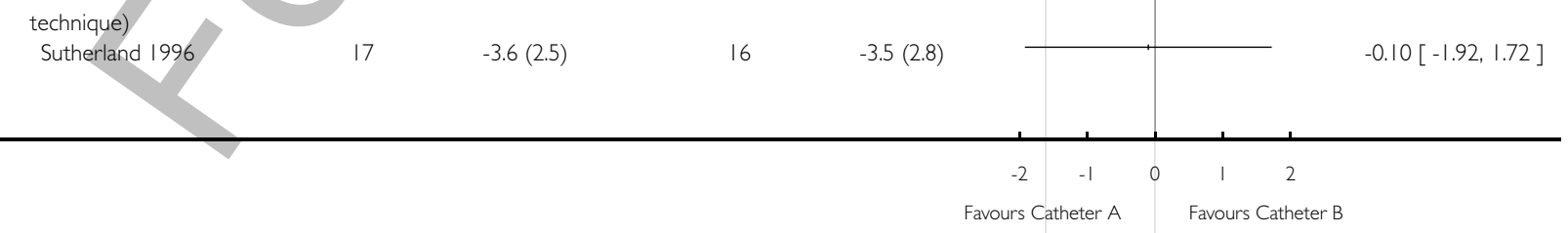


Analysis 3.15. Comparison 3 Hydrophilic-coated or other pre-lubricated catheter versus other catheter (pre-lubricated, coated or uncoated), Outcome 15 Number reporting ease of insertion.

Review: Intermittent catheterisation for long-term bladder management

Comparison: 3 Hydrophilic-coated or other pre-lubricated catheter versus other catheter (pre-lubricated, coated or uncoated)

Outcome: 15 Number reporting ease of insertion

Study or subgroup Catheter $\mathrm{A} \quad$ Catheter $\mathrm{B}$

$\mathrm{n} / \mathrm{N}$

$\mathrm{n} / \mathrm{N}$
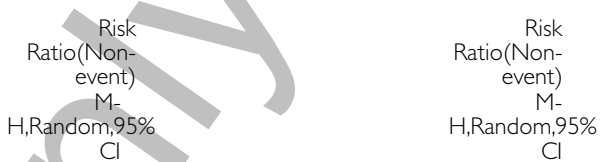

I Hydrophilic-coated catheter, not activated, water added by user (single-use arm, clean technique) versus uncoated catheter, non-lubricated (multi use arm, clean technique)

Pachler 1999

$31 / 32$

$30 / 32$

$0.50[0.05,5.24]$

2 Hydrophilic-coated catheter, not activated, sterile water provided versus hydrophilic-coated catheter, not activated, water added by user (aseptic technique both arms)

Witjes 2009

$72 / 81$

$85 / 88$

$3.26[0.91,11.62]$

3 Hydrophilic-coated activated catheter with integrated bag versus uncoated, pre-lubricated catheter with integrated bag (aseptic technique, single use both arms) Leriche 2006 $20 / 29$ $9 / 29$ $0.45[0.25,0.82]$

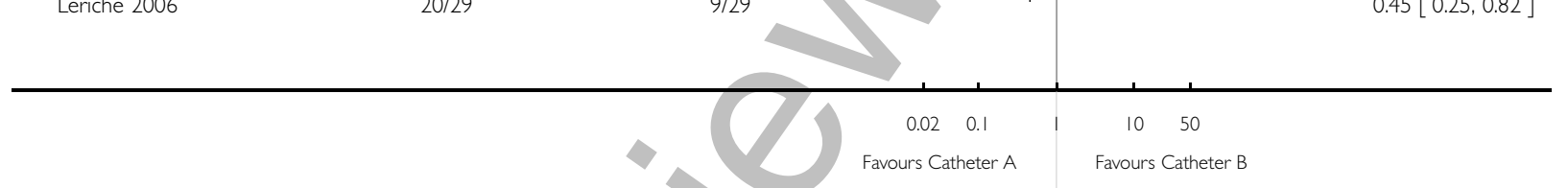


Analysis 3.16. Comparison 3 Hydrophilic-coated or other pre-lubricated catheter versus other catheter (pre-lubricated, coated or uncoated), Outcome 16 Mean ease of insertion.

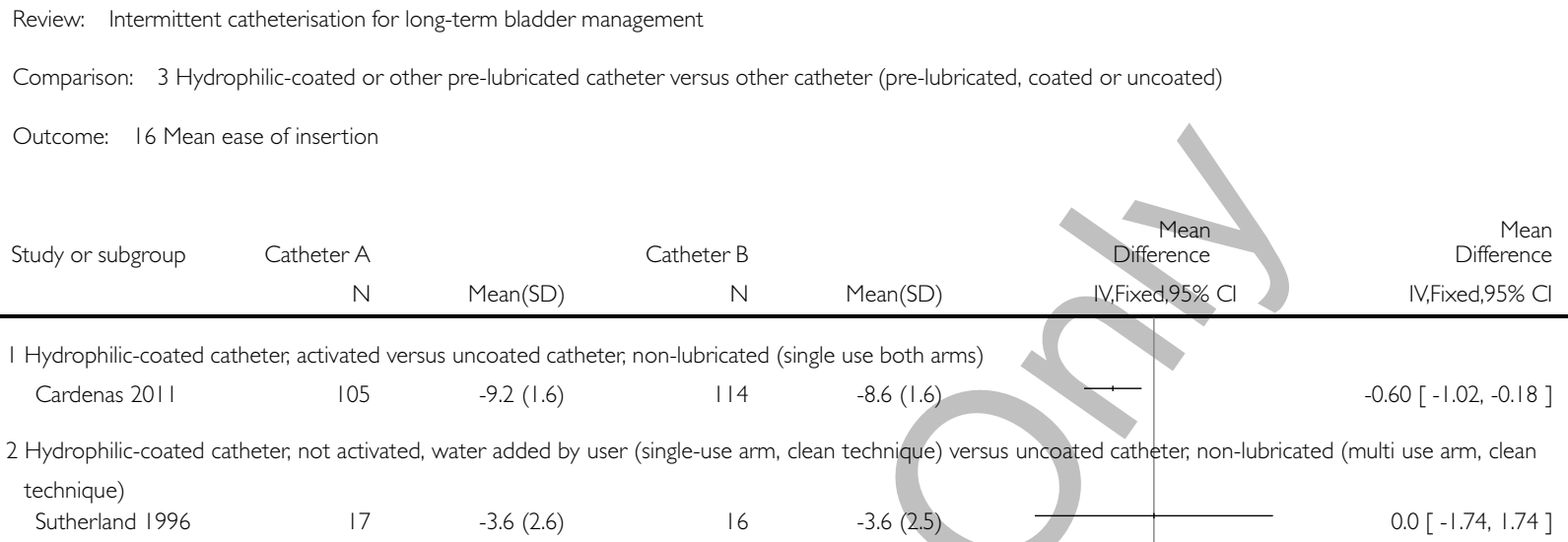

2 Hydrophilic-coated catheter, not activated, water added by user (single-use arm, clean technique) versus uncoated catheter, non-lubricated (multi use arm, clean technique)

Sutherland 1996

$17-3.6(2.6)$

16

$-3.6(2.5)$

$0.0[-1.74,1.74]$

Analysis 3.17. Comparison 3 Hydrophilic-coated or other pre-lubricated catheter versus other catheter (pre-lubricated, coated or uncoated), Outcome 17 Number reporting comfort.

Review: Intermittent catheterisation for long-term bladder management

Comparison: 3 Hydrophilic-coated or other pre-lubricated catheter versus other catheter (pre-lubricated, coated or uncoated)

Outcome: 17 Number reporting comfort

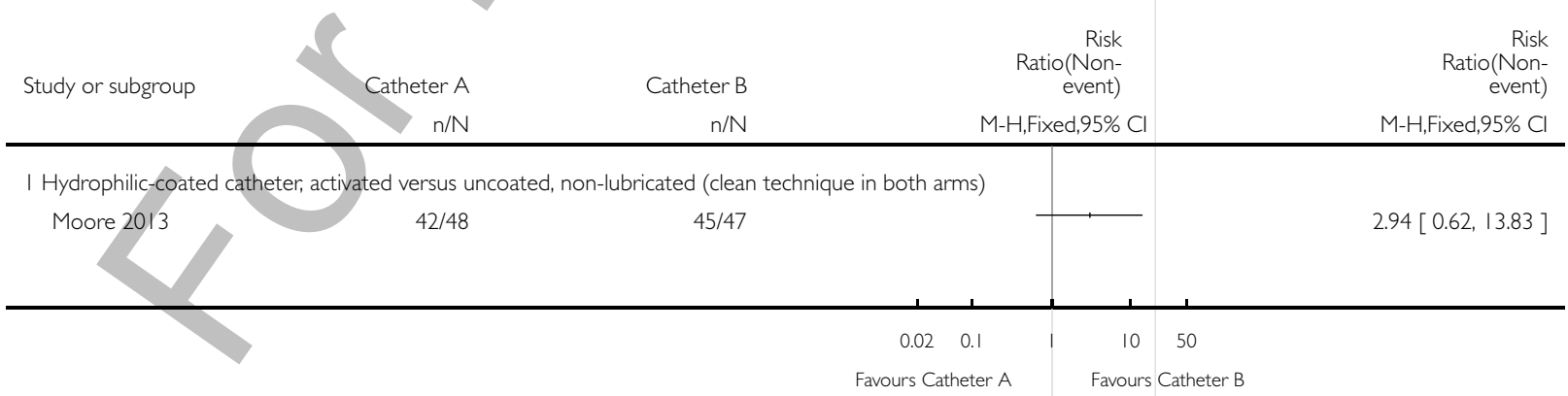


Analysis 3.18. Comparison 3 Hydrophilic-coated or other pre-lubricated catheter versus other catheter (pre-lubricated, coated or uncoated), Outcome 18 Mean ease of removal.

Review: Intermittent catheterisation for long-term bladder management

Comparison: 3 Hydrophilic-coated or other pre-lubricated catheter versus other catheter (pre-lubricated, coated or uncoated)

Outcome: 18 Mean ease of removal
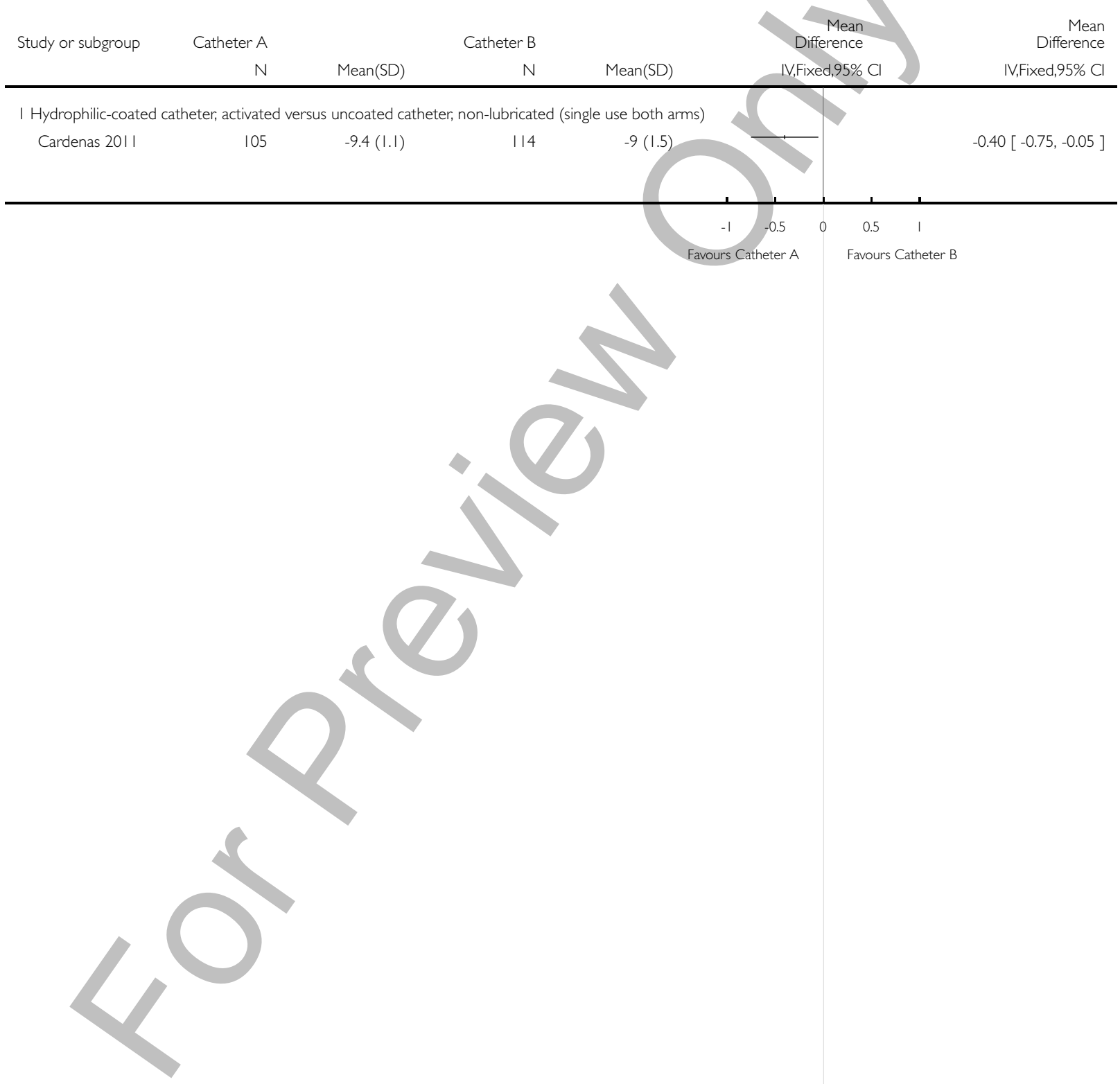
Analysis 4.I. Comparison 4 Standard catheter versus shorter catheter length, Outcome I Number reporting ease of handling.

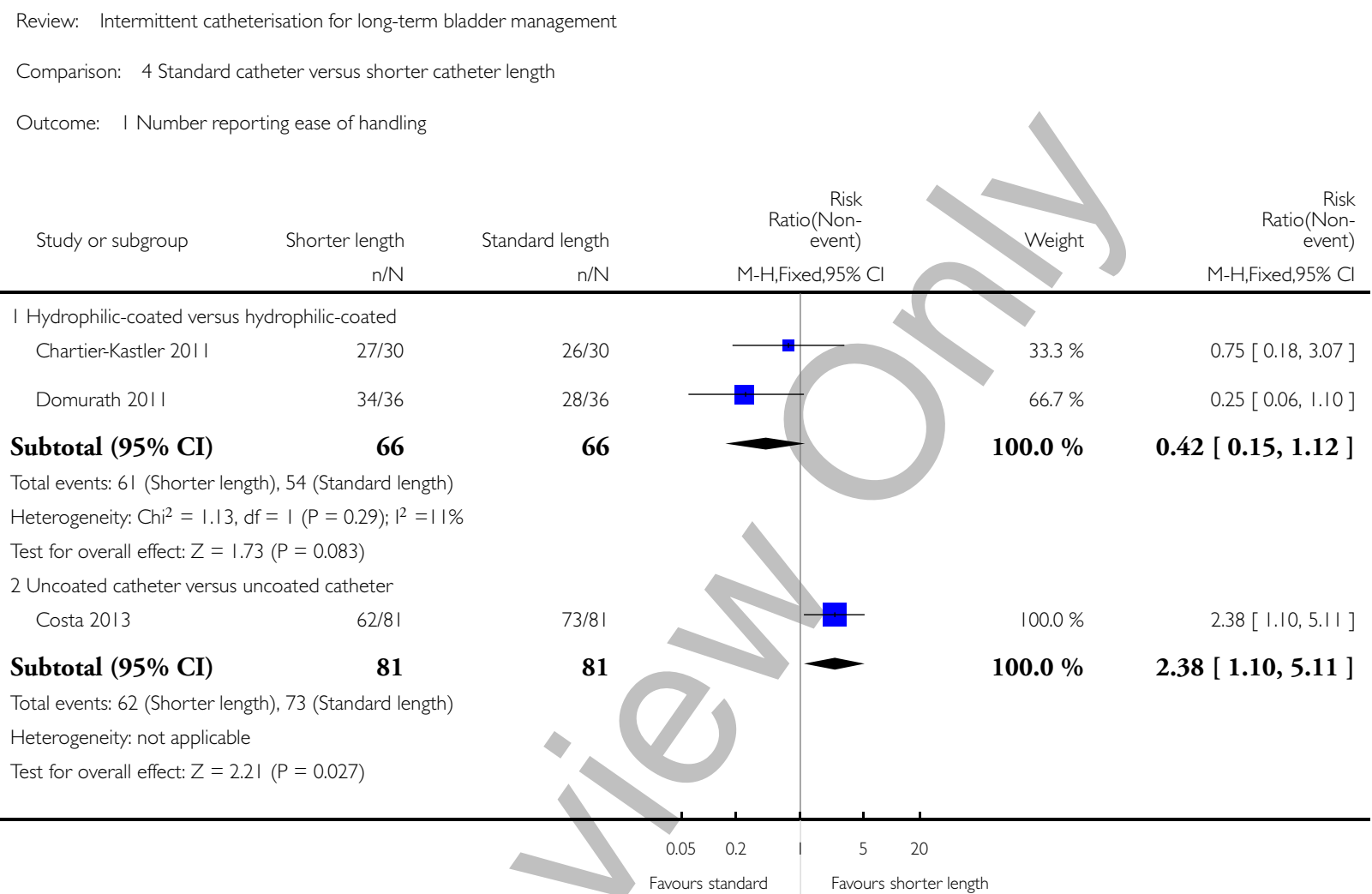

tal $(95 \%$

Favours standard

Favours shorter length 
Analysis 4.2. Comparison 4 Standard catheter versus shorter catheter length, Outcome 2 Number reporting ease of insertion.

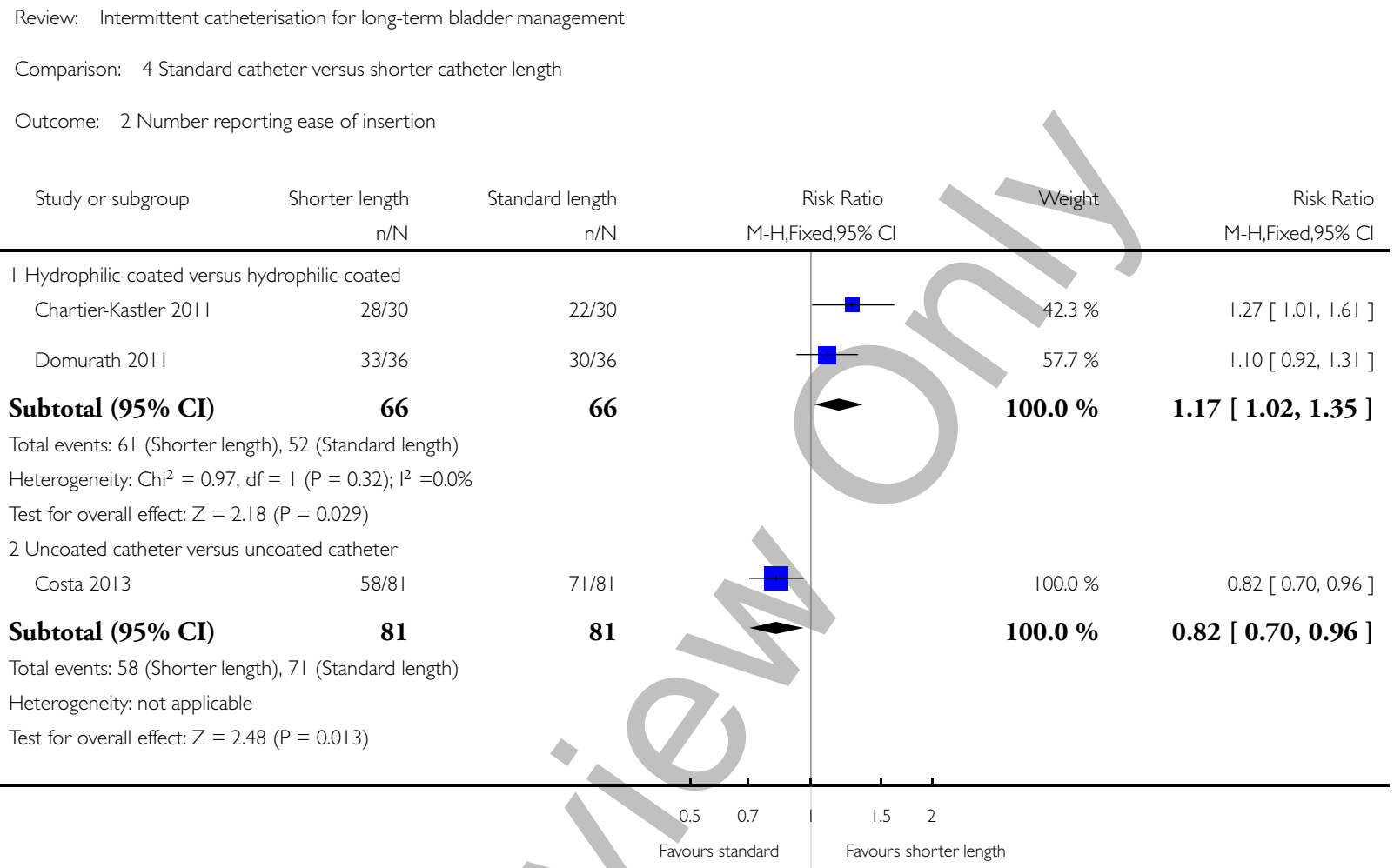


Analysis 4.3. Comparison 4 Standard catheter versus shorter catheter length, Outcome 3 Number reporting product discretion.

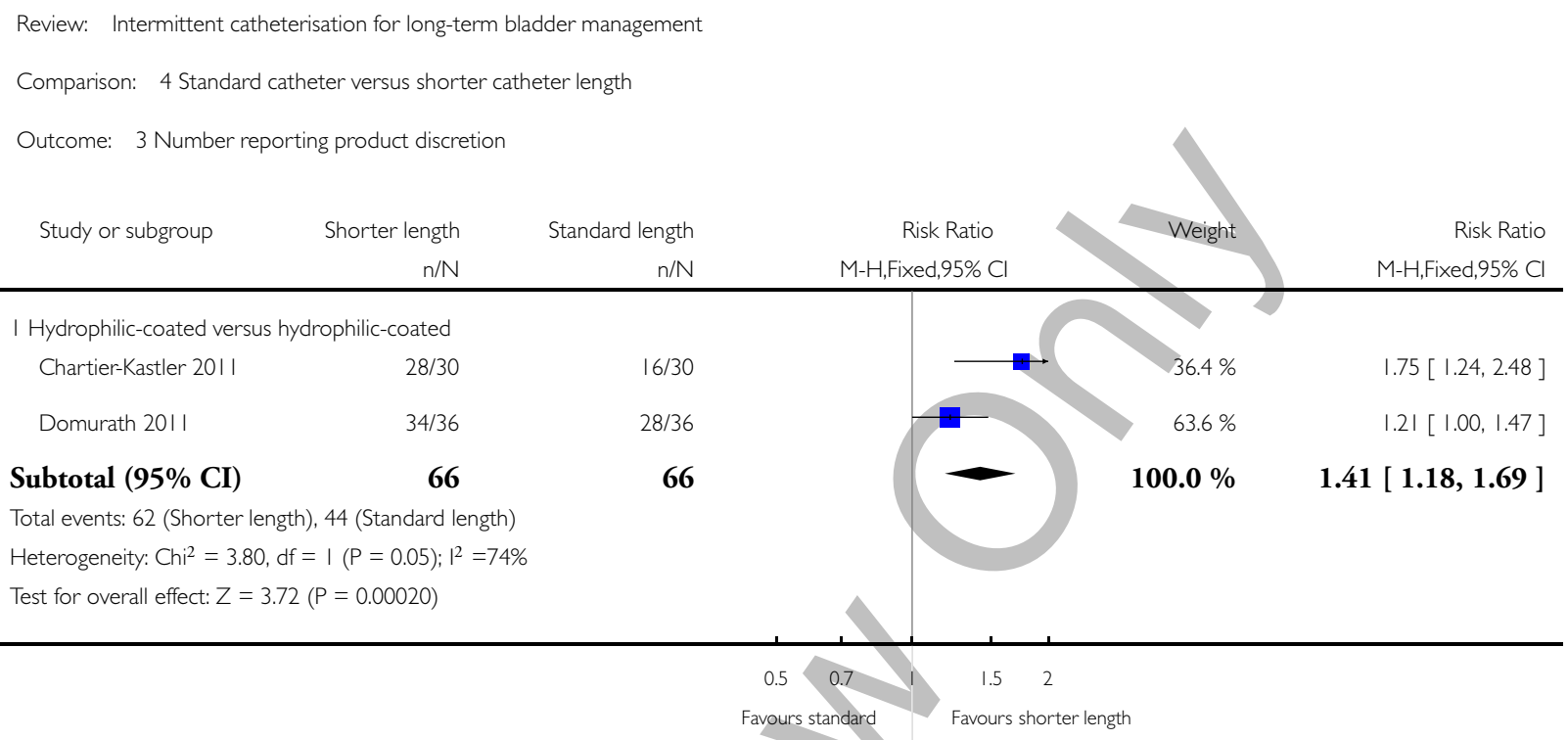

Subtotal $(\mathbf{9 5} \% \mathrm{CI})$

\section{6}

66

$1.75[1.24,2.48]$
$1.21[1.00,1.47]$

Total events: 62 (Shorter length), 44 (Standard length)

Heterogeneity: $\mathrm{Ch}^{2}=3.80, \mathrm{df}=\mathrm{I}(\mathrm{P}=0.05) ; \mathrm{I}^{2}=74 \%$

Test for overall effect: $Z=3.72(P=0.00020)$ 
Analysis 4.4. Comparison 4 Standard catheter versus shorter catheter length, Outcome 4 Number reporting preference.

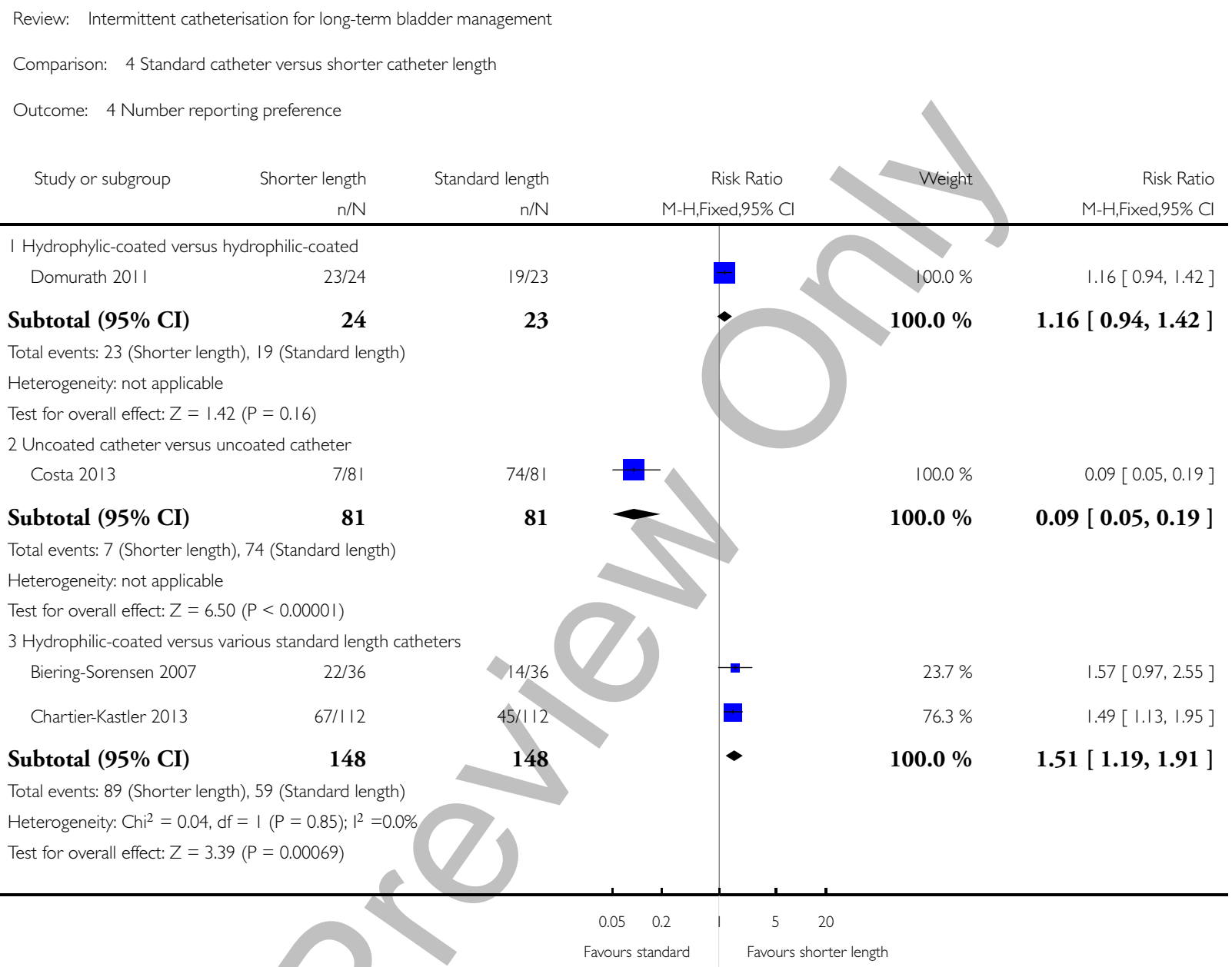




\section{A P P E N D I C E S}

\section{Appendix I. Extra searches performed by the review authors for this update of the review}

Extra specific searches were also performed by the review authors in two additional electronic bibliographic databases: EMBASE from January 1988 to May 2012, CINAHL (January 1982 to May 2012) and ERIC from January 1984 to May 2012. The search terms included individually or combined were: intermittent catheterisation/catheterization; randomised/randomized controlled trials; neurogenic bladder; incomplete emptying; catheter(s); hydrophilic coated, coated, uncoated, bacteriuria, symptomatic urinary tract infection, asymptomatic bacteriuria, asymptomatic urinary tract infection. In addition, to search for trials of catheter cleaning methods, the above terms were combined with the terms: microwaving, catheter cleaning, soap and water, antiseptic soak. However, no additional trials were identified and so no further searches of these databases were undertaken.

\section{WHAT'S NEW}

Last assessed as up-to-date: 30 September 2013.

\begin{tabular}{ll|l}
\hline Date & Event & Description \\
\hline 10 September 2014 & $\begin{array}{l}\text { New citation required but conclusions have not } \\
\text { changed }\end{array}$ & $\begin{array}{l}\text { Added } 17 \text { new studies in this update. Risk of bias was } \\
\text { re-assessed of all the included trials as per current rec- } \\
\text { ommendation }\end{array}$ \\
\hline 10 September 2014 & New search has been performed & $\begin{array}{l}\text { Added } 17 \text { new studies in this update. Risk of bias was } \\
\text { re-assessed of all the included trlas as per current rec- } \\
\text { ommendation }\end{array}$ \\
\hline
\end{tabular}

\section{H I S T O R Y}

Protocol first published: Issue 2, 2006

Review first published: Issue 4, 2007

\begin{tabular}{|c|c|c|}
\hline Date & Event & Description \\
\hline 22 August 2007 & New citation required and conclusions have changed & Substantive amendment \\
\hline
\end{tabular}

Intermittent catheterisation for long-term bladder management (Review) 


\section{CONTRIBUTIONSOFAUTHORS}

JP and MF took the lead in article retrieval and summary of initial findings which were then reviewed and edited as necessary by JP, $\mathrm{MF}$ and KNM. All four review authors contributed towards the writing of the review.

\section{DECLARATIONSOF INTEREST}

Katherine Moore was a co-investigator on a trial sponsored by Coloplast (Cardenas 2011) and received product from Coloplast for another trial (Moore 2013).

Mandy Fader has received intermittent catheter products for research purposes from Astra Tech AB.

\section{SOURCES OF SUPPORT}

\section{Internal sources}

- No sources of support supplied

\section{External sources}

- National Institute for Health Research, UK.

The National Institute for Health Research (NIHR) is the largest single funder of the Cochrane Incontinence Group.

\section{DIFFERENCES BETWEEN PROTOCOL AND REVIEW}

The previous review (Moore 2007) used UTI and other complications for the primary outcomes. In the current review, incidence of UTI remains a key outcome, but we also added outcomes addressing user satisfaction, preference and ease of use for users who are exposed to different designs and materials (e.g. coatings), aseptic or clean technique, single-use or multiple-use catheters, catheterisation by self or others, or any other strategy (including catheter cleaning) designed to reduce UTI. Two trials excluded from the original review (Fader 2001; Pascoe 2001) met the inclusion criteria for the current review. In the current review the Cochrane 'Risk of bias' tool was used to assess all trials, including those in the original review. 